Pontifícia Universidade Católica $_{\text {a }}$

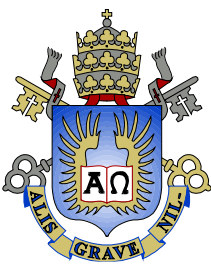

Apaoan Ramos Machado

\title{
A metodologia e a prática matemática cartesiana
}

\section{Dissertação de Mestrado}

Dissertação apresentada como requisito parcial para obtenção do grau de Mestre pelo Programa de Pósgraduação em Filosofia do Departamento de Filosofia da PUC-Rio.

Orientador: Prof. Maxime Rovere

Rio de Janeiro

Junho de 2019 


\section{Apaoan Ramos Machado}

\section{A metodologia e a prática matemática cartesiana}

\section{Dissertação de Mestrado}

Dissertação apresentada como requisito parcial para obtenção do grau de Mestre pelo Programa de Pósgraduação em Filosofia do Departamento de Filosofia da PUC-Rio. Aprovada pela Comissão Examinadora abaixo.

Prof. Maxime Rovere

Orientador

Departamento de Filosofia - PUC-Rio

Prof. Márcio Augusto Custódio Damin

Departamento de Filosofia - Unicamp

Prof. Érico Andrade Marques de Oliveira Departamento de Filosofia - UFPE 
Todos os direitos reservados. É proibida a reprodução total ou parcial do trabalho sem autorização da universidade, do autor e do orientador.

\section{Apaoan Ramos Machado}

Graduou-se em Filosofia pela UFBA (Universidade Federal da Bahia) em 2016. Tem como interesses principais Filosofia Francesa Moderna e estuda a obra do filósofo René Descartes. Os principais temas investigados são método e filosofia da matemática.

Ficha Catalográfica

Machado, Apaoan Ramos

A metodologia e a prática matemática cartesiana / Apaoan Ramos Machado ; orientador: Maxime Rovere. - 2019. 108 f. : il. color. ; $30 \mathrm{~cm}$

Dissertação (mestrado)-Pontifícia Universidade Católica do Rio de Janeiro, Departamento de Filosofia, 2019.

Inclui bibliografia

1. Filosofia - Teses. 2. Descartes. 3. Intuição. 4. Formalismo. 5. Médias proporcionais. I. Rovere, Maxime. II. Pontifícia Universidade Católica do Rio de Janeiro. Departamento de Filosofia. III. Título.

CDD: 100 


\section{Agradecimentos}

Ao meu orientador Prof. Maxime por toda confiança, suporte e, sobretudo, por suas observações para a realização desse trabalho, que não seria possível sem o seu apoio.

Ao CNPq e a PUC-Rio, pelos auxílios, sem os quais não poderia ter ido ao Rio.

Ao Prof. Abel Casanave, que me esclareceu uma série de pontos a respeito da filosofia da matemática. A Davide Crippa, que me auxiliou com o problema das duas médias proporcionais.

Aos meus pais, a meus amigos de Salvador, Heitor e Higor, e aos meus amigos da PUC, especialmente German, Taigon, Hugo e Felipe.

Aos professores da PUC. Ao Prof. Érico Andrade e ao Prof. Márcio Damin, que aceitaram participar dessa banca.

A Edna, que sempre me auxiliou. 


\section{Resumo}

Machado, Apaoan Ramos; Rovere, Maxime. A metodologia e a prática matemática cartesiana. Rio de Janeiro, 2019. 108p. Dissertação de Mestrado - Departamento de Filosofia, Pontifícia Universidade Católica do Rio de Janeiro.

O objetivo desse trabalho é a apresentação de alguns elementos da metodologia e prática matemática elaborada por Descartes. Primeiramente, apresenta-se a "questão da certeza das matemáticas", um dos debates metodológicos de maior relevância no século XVII. Os iniciadores da discussão apontavam que a matemática não se adequava à ciência demonstrativa aristotélica. Porém, tal tese foi rebatida por outros matemáticos. E coube a estes a tarefa de reconstruir, conforme os moldes da silogística, as demonstrações da matemática clássica, a fim de restaurar o status científico da matemática. Descartes não participou ativamente desse debate, distanciando-se não só da colocação do problema inicial como também das propostas de redução silogística. Pode-se ademais afirmar que o modelo metodológico de Descartes para as matemáticas é uma antítese de ambos os projetos. Pretende-se, portanto, apresentar a visão metodológica cartesiana, manifestada, sobretudo, no texto das Regras em sua crítica ao formalismo, no papel que atribui aos princípios e na função metodológica da intuição. Por fim, é apresentada a reconstrução histórica do problema das duas médias proporcionais (duplicação do cubo), que vai da década de 1620 até início de 1630. O resultado dessa prova, que será mais tarde publicada no livro III d'A Geometria, é na verdade fruto das trocas do círculo matemático que envolvia Descartes, Hardy, Mydorge, Beeckman, Mersenne e Roberval. A prova de Descartes (elaborada provavelmente em conjunto com Mydorge) e aquela de Roberval do mesmo problema guardam, contudo, uma diferença. Roberval buscava, diferentemente de Descartes, conciliar o projeto metodológico aristotélico e a prática matemática euclidiana. Assim, a comparação das provas permite ao mesmo tempo uma ilustração dos elementos da metodologia e da prática matemática cartesiana. 


\section{Palavras-chave}

Descartes; intuição; formalismo; médias proporcionais. 


\section{Résumé}

Machado, Apaoan Ramos; Rovere, Maxime (directeur de thèse). La méthodologie et la pratique mathématique cartésienne. Rio de Janeiro, 2019. 108p. Dissertação de Mestrado - Departamento de Filosofia, Pontifícia Universidade Católica do Rio de Janeiro.

Le but de cette mémoire est la présentation de quelques éléments de la méthodologie et la pratique mathématique développées par Descartes. En premier lieu, on analyse « la question de la certitude dans les mathématiques », l'un des plus importants débats autour de la méthodologie mathématique durant le XVIIe siècle. Les précurseurs de cette discussion ont souligné que la mathématique ne pourrait pas être formalisée selon le modèle de la science démonstrative aristotélicienne. Cependant, cette thèse-ci était objectée par un autre groupe de mathématiciens, qui ont essayé reconstruire les démonstrations de la mathématique classique, selon le modèle syllogistique, afin de rétablir le statut scientifique des mathématiques. En effet, Descartes n'a pas participé activement de ce débat, sans jamais essayer une réduction syllogistique. On peut affirmer encore que la perspective méthodologique cartésienne en ce qui concerne les mathématiques n'est qu'une antithèse des deux projets, c'est-à-dire de ceux qui ont défendu la réduction syllogistique et de ceux qui s'y sont opposé. On analyse ainsi la perspective méthodologique cartésienne, mise en évidence surtout dans les Règles dans sa critique au formalisme, incarnée dans le rôle des principes et la fonction méthodologique de l'intuition. Finalement, on fournit la reconstruction historique du problème de deux moyennes proportionnelles (ou duplication du cube) pendant les années 1620 et début des années 1630. Le résultat de cette preuve, qui sera publiée plus tard dans le livre III de La Géométrie, est en fait le fruit des échanges du cercle mathématique qui a impliqué Descartes, Hardy, Mydorge, Beeckman, Mersenne e Roberval. La démonstration de Descartes (conçue probablement avec Mydorge) et celle de Roberval du même problème ont une différence. Roberval cherchait, contrairement à Descartes, concilier le projet méthodologique aristotélicien avec la pratique mathématique euclidienne. Ainsi, la comparaison entre ces deux preuves permet à la fois une illustration des 
éléments de la méthodologie et de la pratique effective de la mathématique cartésienne.

\section{Mots-clés}

Descartes; intuition; formalisme; moyennes proportionnelles. 


\section{Sumário}

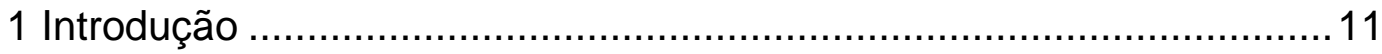

1.1 A metodologia e a prática matemática cartesiana............................11

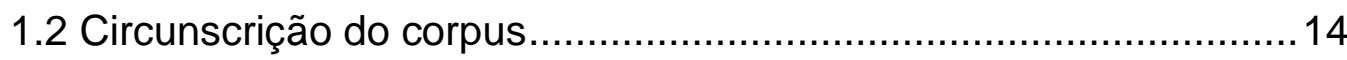

2 Crítica cartesiana ao formalismo silogístico ........................................16

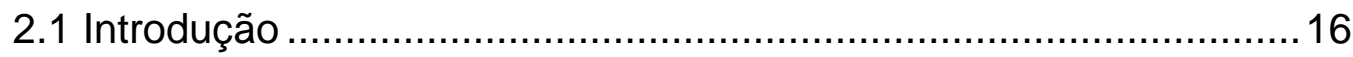

2.2 Ciência demonstrativa aristotélica..................................................16

2.3 A questão da certeza das matemáticas no século XVI ...................19

2.4 Descartes contra o formalismo silogístico .......................................25

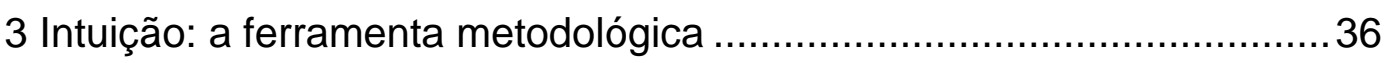

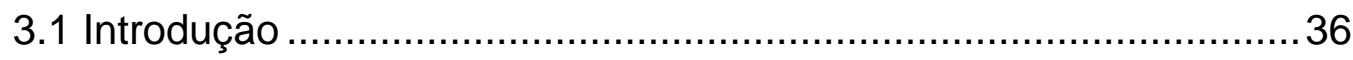

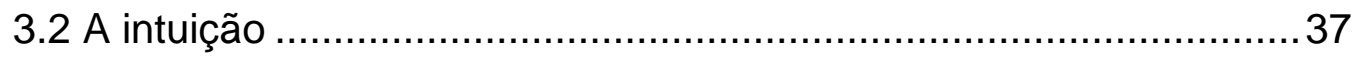

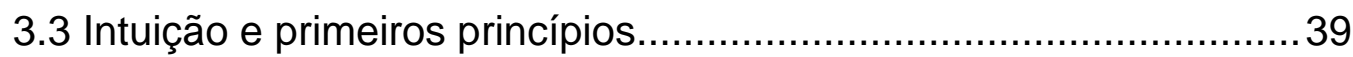

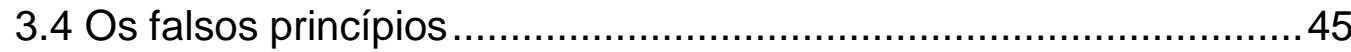

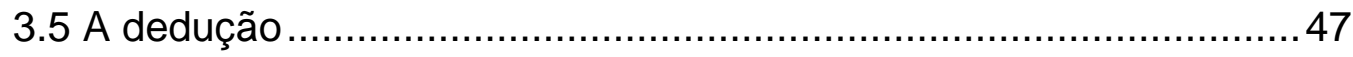

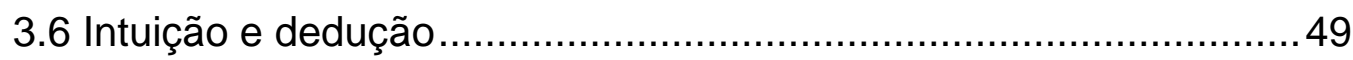

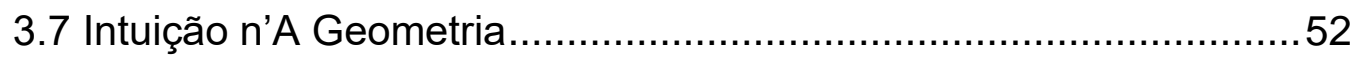

4 Duas médias proporcionais: Descartes entre Roberval e Mydorge ......57

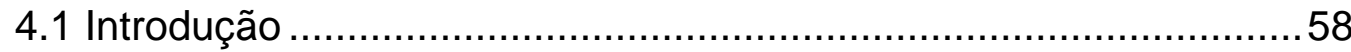

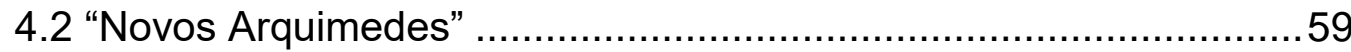

4.3 O problema das duas médias proporcionais na correspondência...64

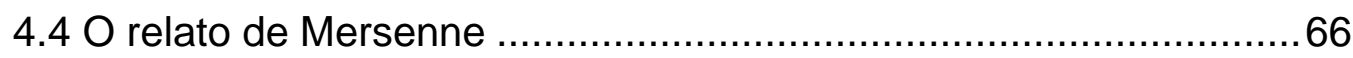

4.5 Comentário às demonstrações ....................................................70

4.6 Roberval e o livro II d'Os Elementos............................................73

$4.7 \mathrm{O}$ exato versus o co-exato: uma interpretação de Manders..............76

4.8 A influência de Mydorge........................................................... 84

4.90 "segredo universal": a demonstração de Descartes ......................88

4.10 Duas médias proporcionais n'A Geometria .................................92

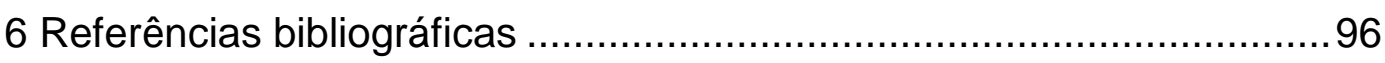

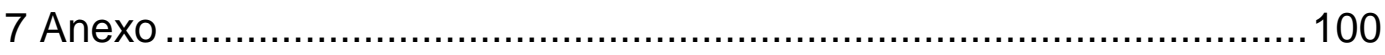


7.1 Costrução de Mydorge para duas médias proporcionais (Journal de

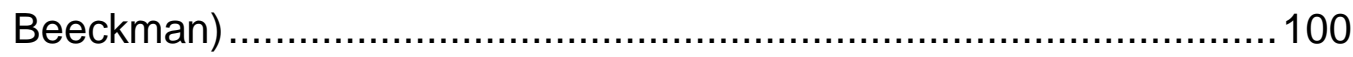

7.2 Método geral de Descartes (Journal de Beeckman) .....................102

7.3 Construção de Roberval para duas médias proporcionais (Harmonie universelle contenant la théorie et la pratique de la musique) ............104 


\section{Introdução}

\section{1}

\section{A metodologia e a prática matemática cartesiana}

Nos últimos tempos, ganharam notoriedade os debates sobre discussões metodológicas no âmbito das matemáticas, veiculadas por obras que puseram em destaque um dos mais célebres dos séculos XVI e XVII: a Quaestio de Certitudine Mathematicarum (ou simplesmente, "questão da certeza das matemáticas"). O trabalho mais representativo sobre esse tema foi escrito por Paolo Mancosu, sem, contudo, nos esquecermos das mais recentes contribuições (notadamente, as de Risi e de Casanave). ${ }^{1}$

Que foi esse debate? Em linhas gerais, essa discussão, que atravessou os séculos XVI e XVII, punha à prova a matemática (notadamente a geometria euclidiana), acomodando-a aos moldes dos mecanismos metodológicos da ciência demonstrativa aristotélica. A aparente e inicial incompatibilidade entre a geometria euclidiana e a lógica aristotélica, que foi atestada por personagens como Alexandre Piccolomini e Benito Pereyra, veio à tona por meio da constatação de que algumas informações diagramáticas escapavam à formalização silogística. Por fim, a conclusão dos contestadores era a seguinte: a matemática (em especial a mais bem fundada de todos os seus ramos: a geometria) não era científica, uma vez que suas demonstrações não seriam causalmente demonstradas. Contudo, essa tese foi rebatida por outros matemáticos, como Christophorus Clavius e Isaac Barrow, cabendo-lhes a tarefa de reelaborar, conforme os moldes da silogística, essas demonstrações geométricas, a fim de restaurar o status de ciência das matemáticas até então descreditado.

Nessa querela que estava em jogo a cientificidade das matemáticas, os especialistas contemporâneos ressaltaram as reconstruções de demonstrações euclidianas e o amadurecimento de concepções distintas de como proceder nas

\footnotetext{
${ }^{1}$ Cf. MANCOSU (1996), DE RISI (2016) e CASANAVE (a ser publicado).
} 
provas matemáticas. É sob a influência e na esteira de algumas das preocupações que moveram esses especialistas nos últimos anos que se encontra a motivação investigativa desse trabalho.

De fato, se pensarmos numa relação com as reivindicações da Quaestio, chegamos ao veredicto que Descartes jamais se dedicou à tarefa da formalização da geometria euclidiana, considerando-a, aliás, uma atividade de matemáticos menores, ou "pequenos Geômetras". Além do mais, que ele confira à matemática um lugar privilegiado entre os diversos ramos do conhecimento, disso não há dúvidas. Dito doutro modo, ele responderia afirmativamente à questão fundamental imposta pela Quaestio quanto à cientificidade das matemáticas. Apesar dessa resposta óbvia, resta ainda saber como Descartes lidaria com as questões mais sutis de como proceder nas demonstrações e de como isso se conecta com a reflexão posterior dessa prática, que chamamos "método".

Entretanto, nosso objetivo não é determo-nos na querela e seus personagens principais, reconstruindo-os, nem muito menos extrair da Quaestio respostas sobre a geometria cartesiana, mas oferecer uma visão geral da noção de prova de Descartes, que pode ser entendida em parte como uma reação às concepções de prova e rigor matemático desenvolvidos nesse contexto. A resposta cartesiana, contudo, se manifesta em dois eixos: sua abordagem metodológica e sua efetiva prática matemática. O posicionamento de Descartes frente às ferramentas de formalização silogística e a introdução de uma concepção intuitiva de deduções, por exemplo, fazem parte da sua visão metodológica. Por outro lado, o seu modo de proceder nas demonstrações fazem parte de sua prática concreta.

Embora muito já se tenha explorado a crítica cartesiana ao formalismo silogístico (que é desenvolvida nos seus escritos a respeito do método: Regras e Discurso do Método), ainda não foram exploradas, conjuntamente, sua posição metodológica e sua efetiva prática matemática. ${ }^{2}$ Com efeito, o projeto metodológico de Descartes, que a propósito se radica nas matemáticas e é melhor nelas empregado, não foi deveras desenvolvido em paralelo com seu modo de proceder nas demonstrações, que, insista-se, não é o mesmo que as analisar

\footnotetext{
${ }^{2}$ Abra-se aqui exceção a Rabouin, que em seu último artigo propõe esse tipo de abordagem. Cf. RABOUIN (2018).
} 
matematicamente, sem pôr questões acerca do raciocínio diagramático, ou identificação de passos implícitos e provas abreviadas, entender como funciona a visualização dos diagramas, compreender se o papel do diagrama é meramente heurístico ou se a prova dele depende substancialmente. Essas questões suscitadas nos parecem quase sempre deixadas de lado, dando-se um protagonismo muito maior ora ao método (esvaziado de sua experiência matemática), ora à análise puramente matemática de suas provas (sem o espírito metodológico de seu autor). Em suma, o objetivo do presente texto é oferecer uma perspectiva da obra de Descartes à luz da sua metodologia matemática, sem perder de vista a sua efetiva prática matemática.

Dito isso, quais seriam precisamente, então, os temas reunidos para a realização do objetivo posto? Nesse trabalho, colocarei em evidência a intuição cartesiana como uma importante ferramenta metodológica aplicada às matemáticas. Consequentemente, ao abordar a intuição, não a examinarei apenas a partir dos comentários sobre o método, mas a sua aplicação efetiva nas matemáticas (destacando alguns usos n'A Geometria, e que são não raramente negligenciados). A intuição joga nas Regras um importante papel no que se refere à ontologia do objeto matemático. Contudo, as discussões sobre a ontologia do objeto matemático, por exemplo, não estão aqui incluídas, interessando-nos muito mais a relação da intuição com elementos da demonstração, que são os princípios e as deduções. A depreciação da formalização silogística na resolução de problemas matemáticos não implica uma negação da noção de prova, mas uma concepção reativa e heterodoxa em comparação a muitos dos autores que tomaram partido da defesa da cientificidade das matemáticas, insuflando o conceito de prova matemática, guiados pelo modelo de ciência demonstrativa aristotélica.

Seria, contudo, defeituoso proceder em busca duma concepção de prova sem as abordar diretamente. Para além da aplicação do artifício metodológico genuinamente cartesiano, que é a intuição, às matemáticas, e das novas conclusões que podem ser alcançadas de como opera a intuição na perspectiva de sua prática matemática, cabe ainda fazer o caminho inverso. Isso significa colher informações de sua prática matemática partindo mera e simplesmente de sua abordagem real, isto é, nas demonstrações. Ao fazer isso, são levadas em conta três vantagens: primeiramente, não temos a necessidade de pressupor a fidelidade de sua prática 
ao seu método; em segundo lugar, constituintes, antes invisíveis à questão de ordem metodológica, passam a ganhar evidência; e por fim, esse tipo de abordagem parece ser mais fiel à efetiva prática matemática de Descartes.

\section{2}

\section{Circunscrição do corpus}

A fim de delimitar a questão a ser abordada, passemos à circunscrição do corpus. Antes de tudo, não há meios de abordar à metodologia cartesiana sem se referir aos textos que tratam diretamente do método cartesiano (Regras e Discurso). Esses textos, todavia, podem ser investigados segundo diversas perspectivas. Mas em virtude de um tratamento que privilegie a discussão metodológica às matemáticas, o que ganhará destaque serão as passagens que nos levam, de algum modo, ao papel da intuição, ferramenta metodológica genuinamente cartesiana que é exercitada no contexto matemático. Aproveitarnos-emos dos textos do método o que se pode chamar de uma teoria geral sobre o papel da intuição. Em seguida, com o propósito de oferecer um contrapeso à teorização da intuição, não poderia passar despercebido a sua aplicação n'A Geometria se se quer apresentar uma compreensão concreta da sua aplicação. Afinal, é na sua efetiva prática matemática que podemos encontrar a confirmação e a ilustração dessa ferramenta metodológica.

Como se sabe, Descartes não nos legou fartos comentários do que ele entendia como uma boa prova e nenhuma reflexão exaustiva sobre sua maneira de proceder nas demonstrações. Contudo, penso ser possível uma reconstrução disso a partir de dois modos, a saber: primeiramente, da sua própria prática matemática - que pode ser visitada não somente n'A Geometria, mas também em suas cartas e conversações com outros matemáticos; em segundo lugar, de suas escolhas no que se refere às demonstrações que ele tinha a sua disposição, mas, por suas exigências, preferiu esta ou aquela, rejeitando outras.

A fim de extrair da prática matemática de Descartes sua noção de prova, nada como adentrar o desenvolvimento de um determinado problema matemático. Com a disseminação de trabalhos acerca da gênesis da geometria cartesiana e do interesse por textos que, embora estejam ao largo da sua obra principal ( $A$ 
Geometria), podem também iluminá-la, proponho a análise do desenvolvimento do problema da construção de duas médias proporcionais. ${ }^{3}$ Esse problema em especial consegue preencher as duas exigências sugeridas acima, estando acompanhada dalguns comentários na sua correspondência e havendo outras provas que nos permite a comparação. A diversidade de matemáticos que lidavam com o mesmo problema, dá-nos a rica chance de cotejar e contrastar o modo de prova de Descartes com o de outros matemáticos. Surge, ademais, a oportunidade de elucidar algumas ligações nas quais Descartes encontrava-se imerso, seja apontando as possíveis cooperações ou influências recebidas.

Essa é, de fato, uma oportunidade de acompanhar o desenvolvimento de uma demonstração que surge ao grande público n'A Geometria, em 1637, mas que foi debatida e construída por muitas mãos, já na década de 1620, mais precisamente numa rede que envolveu Beeckman, Mersenne, Mydorge, Hardy, e sem esquecer Roberval, matemático de tendência contrária a Descartes quanto ao modo de proceder nas provas e engajado na reconstrução da geometria euclidiana. Assim, além da grande obra matemática de Descartes, teremos de acessar os textos do Journal, de Beeckman, alguns textos de Mersenne, onde a demonstração de Descartes e Roberval foi publicada, e a correspondência de Descartes.

\footnotetext{
${ }^{3}$ Cf. RABOUIN (2018).
} 


\section{Crítica cartesiana ao formalismo silogístico}

\section{1}

\section{Introdução}

Antes de analisar a "questão da certeza nas matemáticas", um dos debates metodológicos mais importantes nas matemáticas durante o século XVI e XVII, é preciso fazer algumas considerações sobre a metodologia aristotélica. Esta última não foi senão o suporte que orientou a determinação da legitimidade das demonstrações, na visão de muitos dos matemáticos da época. E, por isso mesmo, a analisaremos antes de adentrar a querela, a fim de mostrar alguns dos conceitos preliminares na introdução do texto.

Em seguida, exploraremos alguns aspectos da crítica cartesiana ao formalismo silogístico. Diferentemente dos matemáticos que participaram da Quaestio, Descartes não desenvolve uma noção de certeza matemática que segue os moldes da metodologia aristotélica. Ainda que aceite o corpus tradicional da geometria e da aritmética, Descartes não pensa que os critérios de legitimação devam vir por meio da metodologia aristotélica. Por isso mesmo, a concepção cartesiana de demonstração (que só será exemplificado ao fim desse trabalho) se distingue dos matemáticos que defenderam a certeza das matemáticas a partir do suporte da ciência demonstrativa.

\section{2}

\section{Ciência demonstrativa aristotélica ${ }^{4}$}

\footnotetext{
${ }^{4}$ A ciência demonstrativa aristotélica é tratada nos Segundos Analíticos. A lógica aristotélica, encarnada no Organon, compreende essencialmente quatro partes. Cada parte se dedica um estudo: dos elementos mais básicos da predicação (conceitos, ou termos), um sobre a natureza da proposição, um sobre o silogismo (válido) e outro sobre o silogismo científico. Essas quatro partes se manifestam na própria divisão do texto: As categorias, Da interpretação, Primeiros Analíticos e Segundos Analíticos. Posterior a Descartes, mas de inspiração cartesiana, o tratado de lógica mais conhecido da modernidade, La logique ou l'art de penser (A lógica de Port-Royal), escrito por Arnauld e Nicole, divide a lógica em quatro partes, que são conceber, julgar, raciocinar e ordenar. Esta última parte, Arnauld a identifica com o método.
} 
Segundo Aristóteles, é preciso que a demonstração científica esteja fundada sobre proposições que não sejam elas mesmas demonstradas, os princípios. Estes evitam que a justificação retroceda ao infinito e também que haja uma demonstração em círculo. ${ }^{5}$ Assim, a ciência demonstrativa (ou apodítica) exige um conjunto de proposições verdadeiras, universais e acima de tudo indemonstráveis. Embora a noção de ciência esteja intimamente relacionada com a apresentação de uma demonstração, nem tudo pode ser demonstrado. É necessário que haja um conjunto de premissas iniciais que não sejam elas mesmas resultado de uma demonstração.

Aristóteles explica que esses princípios podem ser de diversas naturezas, a saber: axiomas, definições e hipóteses. Quanto aos axiomas, ou princípios comuns, eles podem ser de dois tipos. Em primeiro lugar, há os axiomas que são princípios lógico-metafísicos, comuns a todo domínio de ser, sendo partilhados por todas as ciências (isto é, princípio de identidade, de não contradição e do terceiro excluído). Em segundo, há axiomas de menor generalidade, mas que são comuns a algumas ciências. Por outro lado, as definições e hipóteses são próprias de cada ciência, e por isso mesmo ele também os chama de princípios próprios. Mas, enquanto as definições expressam o que alguma coisa é, apresentando o significado do termo em questão, as hipóteses supõem a existência dos elementos mais básicos de uma determinada ciência. Convém ainda observar que, à diferença dos outros princípios, os axiomas lógico-metafísicos, não são explicitados no sistema axiomático de uma ciência, pois a prova não funciona a partir deles, mas através deles. ${ }^{6}$

O conhecimento científico é, com efeito, obtido estritamente através da demonstração, mais precisamente pela demonstração silogística. Essas demonstrações devem, primeiramente, seguir os critérios de validade formal, explicadas por Aristóteles ao longo dos Primeiros Analíticos. Assim, o silogismo

\footnotetext{
${ }^{5}$ Cf. Segundos Analíticos I, 9, 72b 5 -73a 35.

${ }^{6}$ Cf. Segundos Analíticos I, 9, 76a 30 -77a 35. Esses princípios aristotélicos foram postos muitas vezes em comparação com os princípios da geometria euclidiana (definições, noções-comuns e postulados). Nos Segundos Analíticos, tantos os exemplos das demonstrações científicas como os dos princípios são invariavelmente geométricos, que explica de algum modo a tendência de muitos leitores a criar uma correspondência entre ambas as obras. Veja-se, por exemplo, o axioma, citado por Aristóteles, que se aplica às quantidades em geral: "se se retira partes iguais de coisas iguais, restam coisas iguais" com a noção-comum euclidiana I.3: "E, caso de iguais sejam subtraídas iguais, as restantes são iguais”. Cf. Segundos Analíticos I, 9, 76a 42 e 77a 30.
} 
demonstrativo é antes de qualquer coisa um silogismo formalmente válido, do qual se as premissas são verdadeiras, a conclusão também será necessariamente verdadeira. Além do mais, as demonstrações devem partir de princípios (ou premissas iniciais) que devem obedecer alguns critérios que escapam ao enquadramento lógico e que podem ser entendidos mais como epistemológicos ou metodológicos. São eles, nomeadamente: o de serem verdadeiros, primeiros, imediatos, mais conhecidos, anteriores e causais. ${ }^{7}$

De todos os critérios o mais banal é a verdade, afinal não pode haver ciência do falso. Tendo esse critério escapado à formulação puramente lógica dos Primeiros Analíticos, a verdade das premissas deve ser garantida para que a conclusão do silogismo seja igualmente verdadeira. Os princípios são primeiros, porque indemonstráveis. Assim, antecedem as proposições que podem ser demonstradas. Ademais, são imediatos, isto é, acessados sem a ajuda de um termo médio, diferentemente das conclusões dos silogismos que só o são por meio de um termo médio que integra o silogismo. São também anteriores e mais conhecidos em relação às proposições que se seguem dos princípios e premissas, ou seja, as conclusões.

Contudo, é a noção de causa que merece uma atenção particular. Segundo Aristóteles, a causa não é senão o porquê da conclusão. E é tão somente o termo médio do silogismo que apresenta a causa da conclusão. A apresentação da causa eleva o simples silogismo válido a um silogismo científico. A ciência (estrita) aristotélica é aquele tipo de conhecimento que consegue ser feito por meio de demonstrações que evidenciam a causa. A partir de noção de causalidade, Aristóteles faz ainda outra distinção: a demonstração do que e a demonstração do porquê. ${ }^{8}$ A primeira apenas mostra que algo é, mas é somente a segunda que apresenta a causa e, portanto, pode ser considerado científico. O exemplo da demonstração do que (não causal) usado pelo autor é a seguinte:

Os planetas não cintilam.

O que não cintila está próximo da Terra.

\footnotetext{
${ }^{7}$ Cf. Segundos Analíticos I, 2, 71b 20-25.

${ }^{8}$ Cf. Segundos Analíticos I, 13, 78a 20-79a 15.
} 
Logo, os planetas estão próximos da Terra.

Na realidade, esclarece Aristóteles, os planetas não estão próximos da Terra porque eles não cintilam, mas eles não cintilam porque estão próximos da Terra. Eis, portanto, a demonstração científica que nos mostra a causa de que isso seja assim.

O que está próximo da Terra não cintila.

Os planetas estão próximos da Terra.

Logo, os planetas não cintilam.

Esses conceitos fundamentais fazem parte da estrutura da ciência demonstrativa aristotélica. Ademais, serão retomados no século XVI e XVII por matemáticos que acreditavam que a ciência matemática não poderia obedecer a todos eles (sobretudo um deles, o de causalidade). Ao atacar a noção de causalidade nas matemáticas, cairia por terra também a seu status de cientificidade.

\section{3}

\section{A questão da certeza das matemáticas no século XVI}

São as matemáticas que melhor representam as características da ciência demonstrativa, pensava Aristóteles, que ipso facto retira a maior parte de seus exemplos das matemáticas (com especial destaque à geometria). Apesar disso, mais tarde no século XVI, alguns aristotélicos, que aceitavam e defendiam os esquemas gerais da ciência demonstrativa, contestaram a cientificidade das matemáticas. Seus maiores expoentes foram decerto o filósofo italiano Alexandre Piccolomini (1508-1578) e o jesuíta espanhol Benito Pereyra (1535-1610), tendo o primeiro iniciado a discussão em um texto cujo título é Comentário à certeza das disciplinas matemáticas (Commentarium de certitudine mathematicarum disciplinarum), de 1508, e que dá nome à querela.

Com efeito, o que sustentou a posição desses autores não foi senão a declarada incompatibilidade entre as demonstrações da geometria euclidiana e as exigências metodológicas aristotélicas. Assim, a pretexto de uma estrita fidelidade à letra do texto de Aristóteles, esses autores passaram a descreditar as 
matemáticas, que parecia até então encarnar o modelo de ciência proposto pelo filósofo grego.

Pensavam esses aristotélicos, as demonstrações das matemáticas (exemplificadas, sobretudo, por aquelas da geometria euclidiana) não obedecem plenamente aos critérios da ciência demonstrativa, infringindo justamente a condição de que as premissas sejam causas da conclusão. Assim, atacavam as demonstrações matemáticas, argumentando que não eram causais. E por não serem causais, não poderiam ademais ser consideradas científicas. Já examinada acima a noção de causa é um dos constituintes fundamentais da ciência demonstrativa aristotélica. Demos a palavra a um dos defensores mais expressivos dessa tese, o jesuíta Pereyra:

\begin{abstract}
Minha opinião é que as matemáticas não são propriamente ciências: a essa opinião cheguei tanto por outros, como por este que é o mais eminente dos argumentos. Saber é conhecer uma coisa por causa, pela qual a coisa é; e a ciência é um efeito da demonstração: mas a demonstração (e falo do gênero perfeitíssimo de demonstração) deve ser constituída de coisas que são por si e próprias em relação ao que é demonstrado; assim, as coisas que são por acidente, e comuns, são excluídas das demonstrações perfeitas; com efeito, o Matemático não considera a essência da quantidade, não trata de suas afeições na medida em que decorrem de tais essências nem as considera por causas próprias, em virtude das quais elas não tratam da quantidade, e não realizam suas demonstrações a partir de predicados próprios e por si, mas a partir de comuns e por acidente: portanto, a doutrina matemática não é propriamente uma ciência: A maior [premissa] desse silogismo não precisa ser provada, pois se segue claramente do que foi escrito por Aristót. I. Poster. [livro I dos Segundos Analíticos]. 9
\end{abstract}

\footnotetext{
${ }^{9}$ Argumento retirado início do capítulo XII, cujo título é "Não se diz da Matemática e de outras disciplinas serem univocamente ciências especulativas, pois a doutrina Matemática não é ciência propriamente" (Scientiam speculativam non dici univocè de Mathematicis disciplinis \& alijs, quoniam doctrina Mathematica non est propriè scientia). No original: Mea opinio est mathematicas disciplinas non esse proprie scientias: in quam opinionem adducor tum allis, tum hoc uno maxime e argumento. Scire est rem per causam cognoscere propter quam res est; et scientia est demonstrationis effectus: demonstratio autem (loquor de perfectissimo demonstrationis genere) constare debet ex his quae sunt per se et propria ejus quod demonstratur; quae sunt vero per accidens, et communia, excluduntur a perfectis demonstrationibus; sed Mathematicus necque considerat essentia quantitatis, necque affectionis eius tractat prout manant ex tali essentia, necque declarat eas per proprias causas, propter quas insunt quantitati, necque
} 
No argumento de Pereyra, lê-se claramente a ênfase que ele dá à dimensão causal do que entende por ciência, apoiando-se justamente numa concepção aristotélica.

A crítica daqueles que, como Pereyra, rejeitavam o estatuto das matemáticas como ciência estrita não se reduzia a comentários metodológicos. Esses filósofos examinavam proposições da geometria euclidiana na tentativa de denunciar a incompatibilidade entre esta e a ciência demonstrativa. Todavia, seus argumentos são variados e cobrem uma literatura vasta. Por isso, tomemos tão somente o caso da proposição I.1, que propõe a construção de um triangulo equilátero sobre uma reta limitada dada (vide a figura abaixo).

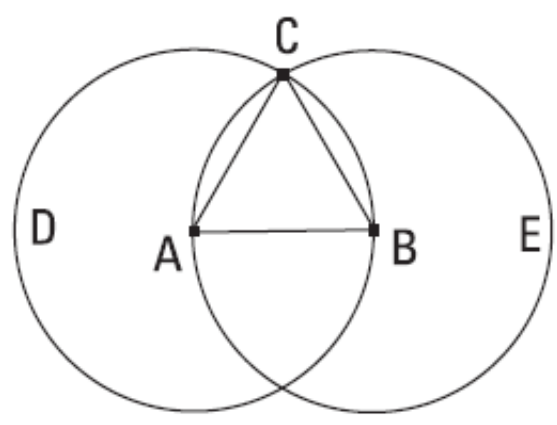

Figura 1 (EUCLIDES, 2009, p. 99)

Segue a demonstração. Seja a reta limitada dada AB. Fique descrito o círculo BCD com centro A e distância AB. Em seguida, fique descrito o círculo ACE com o centro B e com a distância BA. ${ }^{10} \mathrm{~A}$ partir do ponto $\mathrm{C}$, no qual os círculos se cortam, sejam traçadas as retas $\mathrm{CA}, \mathrm{CB} .{ }^{11} \mathrm{E}$, como o ponto A é centro do círculo $\mathrm{CDB}, \mathrm{AC}$ é igual a $\mathrm{AB}$. Do mesmo modo, sendo o ponto $\mathrm{B}$ centro do círculo $\mathrm{CAE}, \mathrm{BC}$ é igual a $\mathrm{BA} .{ }^{12} \mathrm{Se} \mathrm{AC}$ é igual a $\mathrm{AB}$ e $\mathrm{BC}$ é igual a $\mathrm{BA}$, então $\mathrm{AC}$ e $\mathrm{AB}$ são iguais. ${ }^{13}$ Logo, o triângulo $\mathrm{ABC}$ é equilátero.

conficit demonstrationes suas ex praedicatis propiis et per se, sed ex communibus, et per accidens: ergo doctrina mathematica non est proprie scientia: Maior hujus syllogismi non eget probatione, etenim aperte elicitur ex his quae scripta sunt ab Aristot. I. Poster. Cf, PEREYRA, 1585, p. 26.

${ }^{10}$ A construção desses dois passos se justifica com o postulado euclidiano I.3, que diz: "E, com todo centro e distância, descrever um círculo."

11 Justificados pela aplicação do postulado euclidiano I.1, que diz: "Fique postulado traçar uma reta a partir de todo ponto até todo ponto".

12 Justificados pela definição euclidiana I.15 (do círculo), que diz: "Círculo é um figura plana contida por uma linha [que é chamada circunferência], em relação à qual todas as retas que a 
Os passos dessa demonstração não eram aceitos como estritamente lógicos, pois a informação da existência do ponto $C$ não se segue logicamente dos princípios evocados pelo geômetra. Para saber que lá está o ponto $\mathrm{C}$, apelamos ao recurso diagramático. Que haja um ponto $\mathrm{C}$, não é senão a figura que nos informa pela intersecção dos círculos. Quanto a essa demonstração, como ilustra Casanave, os críticos da cientificidade das matemáticas alegavam o seguinte:

[...] que não é porque os círculos descritos coincidem com os vértices que o triângulo é equilátero, mas porque o triângulo é equilátero é que os círculos descritos coincidem nos vértices. De novo, não teríamos uma demonstração científica: os círculos em questão não são notas constitutivas da definição de triângulo equilátero. ${ }^{14}$

Contudo, essa tese de que as matemáticas não seriam causais nem científicas foi rebatida por outros matemáticos, como o jesuíta polonês Christophorus Clavius (1538-1632) e o professor de Cambridge Isaac Barrow (1630-1677). Cabia-lhes, então, a tarefa de reelaborar, conforme os moldes da silogística, essas demonstrações geométricas, a fim de restaurar o status de ciência das matemáticas até então descreditado. Gostaríamos, no entanto, de exibir o que fez Clavius na sua reelaboração silogística da proposição I.1. Embora não tenha se dedicado sistematicamente à reconstrução como Barrow, Clavius defendeu às matemáticas muito mais no campo institucional, argumentando em favor da certeza nas matemáticas e participando da elaboração do material pedagógico a ser ensinado nas escolas jesuítas. ${ }^{15}$ Por essa razão, seu comentário aos Elementos, de Euclides, foi também um dos pilares da formação de Descartes nos tempos em que era estudante de La Flèche. Vejamos como Clavius procede em favor da cientificidade das matemáticas:

Como vês, muitas demonstrações estão contidas em uma proposição. Convém resolver essa primeira proposição por seus primeiros princípios começando pelo último silogismo demonstrativo. Se

encontram [até a circunferência do círculo], a partir de um ponto dos postos no interior da figura, são iguais entre si."

${ }^{13}$ Noção-comum euclidiana I.1, que diz: “As coisas iguais à mesma coisa são também iguais entre si".

${ }^{14}$ Cf. LASSALLE CASANAVE, a ser publicado, p. 36. Mancosu, por outro lado, reconstrói a argumentação de Pereyra impugnando a proposição euclidiana I.32, que demonstra ser igual a dois ângulos retos a soma dos ângulos internos do triângulo. Cf. MANCOSU, 1996, p. 14-15.

${ }^{15}$ Clavius introduz seu comentário aos Elementos de Euclides com um pequeno manifesto em favor da certeza nas matemáticas: In disciplinas mathematicas prolegomena. 
alguém, então, quer provar que o triângulo $\mathrm{ABC}$ é equilátero, construído pelo método previamente mencionado, servir-se-á deste silogismo demonstrativo.

Todo triângulo que tem três lados iguais é equilátero. (definição 23)

O triângulo ABC tem três lados iguais.

Logo, o triângulo $A B C$ é equilátero.

A [premissa] menor confirma-se por este silogismo:

As coisas que são iguais a uma mesma coisa são também iguais entre

si. (axioma 1)

Os dois lados AC e BC são, assim, iguais entre si.

E consequentemente, todos os lados $A B, B C$ e AC são iguais.

A [premissa] menor desse silogismo é alcançada da seguinte maneira:

As linhas retas traçadas a partir do centro até a circunferência do círculo são iguais entre si. (definição 15)

As linhas $A B$ e AC são traçadas do centro até a circunferência [do círculo] $C B D$.

Logo, as linhas $A B$ e AC são iguais entre si.

Pela mesma razão, as linhas $\mathrm{AB}$ e BC serão iguais, se forem traçadas do centro $\mathrm{B}$ à circunferência [do círculo] CAD. Desse modo, a [premissa] menor do silogismo precedente será totalmente confirmada. Do mesmo modo, poderão ser resolvidas todas as outras proposições, não somente as de Euclides, mas também as de outros Matemáticos. (GRIFO NOSSO) ${ }^{16}$

\footnotetext{
${ }^{16}$ No lugar da definição 23 de Clavius, deve-se ser a atual definição 20. No texto original: $U t$ autem videas, plures demonstrationes in una propositione contineri, placuit primam hanc propositionem resolvere in prima sua principia, initio facto ab ultimo syllogismo demonstrativo. $S i$ quis igitur probare velit, triangulum $A B C$, constructum methodo praedicta, esse aequilaterum, utetur hoc syllogismo demonstrante. Omne triangulum habens tria latera aequalia, $d$ est aequilaterum. (d23.def.) Triangulum $A B C$, tria habet aequalia latera. Triangulum igitur $A B C$, est aequilaterum. Minorem confirmabit hoc alio syllogismo. Quae eidem aequalia sunt, e (e1.pron.) inter se quoque sunt aequalia. Duo latera $A C, B C$, aequalia sunt eidem lateri $A B$. Igitur \& duo latera $A C, B C$, inter se aequalia sunt. Ac propterea omnia latera $A B, B C, A C$, aequalia ezistunt. Minorem vero huius syllogismi hac ratione colliget. Linea recta à centro ductae ad circumverentiam circuli, inter sunt aequales. (f.15.def.) Linea $A B, A C$, sunt ductae à centro $A$, ad circunferentiam $C B D$. Sunt igitur lineae $A B, A C$, aequales inter se. Eademq. ratione erunt lineae $A B, B C$, aequales cum ducantur à centro $B$, ad circunferentiam $C A D$. Quamobrem minor
} 
O texto acima faz parte do escólio da proposição I.1 de seu comentário aos Elementos. É interessante notar que, na visão de Clavius, não somente as demonstrações euclidianas, mas as dos outros matemáticos podem ser transformadas em silogismos demonstrativos. Além do mais, oferece-nos uma ilustração da sua tese, decompondo a demonstração em três silogismos na forma de Darii, cujas premissas maiores são proposições indemonstráveis (um axioma e duas definições). ${ }^{17}$ Por fim, conforme a demonstração acima, chega-se à causa última da demonstração, a definição de círculo. Em resumo, o que faz Clavius é um bom exemplo de uma tentativa de reconciliar as demonstrações da geometria euclidiana com a silogística aristotélica.

Houve ainda outras tentativas de formalização mais engenhosas, como a de Barrow, que foi recentemente analisada por Casanave. ${ }^{18}$ Barrow assinala o caráter "entimemático" de sua própria prova, uma vez que torna ocultas algumas premissas em nome da agilidade da prova, mas que são facilmente reconstruídas. Enquanto Clavius reduz a demonstração aos já conhecidos princípios da geometria euclidiana, que são a sua causa, Barrow introduz um novo princípio que não aparece em Euclides, mas que pode ser facilmente aceito (a saber: "círculos iguais descritos por um raio comum se intersectam em um ponto"). E ao introduzir esse princípio, a demonstração de Barrow elimina, por assim dizer, o recurso ao diagrama. O problemático ponto $\mathrm{C}$ da proposição I.1 não decorreria assim da visualização diagramáticas, mas da aplicação mesma do novo princípio. Além disso, Barrow reformula as proposições da demonstração tornando-as universais, que era uma das exigências demonstrativas de Aristóteles, diferentemente de Clavius, que a elabora com proposições particulares. ${ }^{19} \mathrm{Em}$ última análise, há, porém, algo de comum entre as duas posições, a de Barrow e a de Clavius (talvez implícita neste último): além de considerarem as provas euclidianas científicas e causais, a despeito das teses de Pereyra e de outros escolásticos da época, eles também compartilhavam que as provas euclidianas

praecedentis syllogismi tota confirmata erit. Non aliter resolvi poterunt omnes aliae propositiones non solum Euclidis, verum etiam caeterorum Mathematicorum. Cf. CLAVIUS, 1603, p. 82-83.

${ }^{17}$ Darii (AII-1) é a forma silogística de primeira figura cuja premissa maior é universal afirmativa (Todo $\mathrm{S}$ é P), a premissa menor é particular afirmativa (Algum S é P) e a conclusão é particular afirmativa (Algum S é P).

${ }^{18}$ Casanave reconstrói e comenta com detalhes a demonstração de Barrow. Cf. LASSALLE CASANAVE, a ser publicado, p. 36-41.

${ }^{19}$ Cf. Segundos Analíticos I, 4, 73a 20 - 74a 5. 
faziam abreviações de passos que poderiam ser reconstruídos pelo geômetra quando solicitado.

\section{4}

\section{Descartes contra o formalismo silogístico}

É um fato bem conhecido que Descartes jamais se dedicou à tarefa da formalização da geometria euclidiana. Ainda assim, isso não significa admitir que nosso autor não tivesse se deparado com questões daquela época concernentes à demonstração que mobilizavam o quadro conceitual da silogística aristotélica. É bem possível que Descartes estivesse de algum modo familiarizado com essas discussões, que se encontram em autores que ele acessou durante o começo dos seus estudos (como Clavius) bem como alguns matemáticos com os quais chegou a ter algum tipo de troca intelectual (como Mersenne e Roberval).

A posição de Descartes, contudo, passa despercebida, e não sem alguma razão. Em primeiro lugar porque ele não pode ser contado entre o grupo de matemáticos que se dedicavam às reconstruções silogísticas da geometria euclidiana (seja para confirmar o status científico da matemática, seja para negálo). Pode-se acrescentar a isso certa indiferença à pertinência do projeto mesmo, uma vez que Descartes não nos parece incomodado com as dificuldades encontradas por aqueles que negavam o status científico do raciocínio matemático. Chegou ademais a considerar o empreendimento de reconstrução dos problemas euclidianos uma atividade de "pequenos Geômetras". ${ }^{20} \mathrm{E}$ por último mas não menos importante, outro fator que contribuiu à formação dessa imagem é a crítica cartesiana ao formalismo silogístico. Essa última aparece invariavelmente acompanhada com a estima que mantinha Descartes ao cálculo algébrico. Em suma, a análise dos textos cartesianos é triplamente problemática: a ele pode ser imputado a ausência de material, o seu absoluto desinteresse por tais reconstruções da geometria euclidiana e sua crítica contundente à silogística aristotélica.

$\mathrm{Na}$ verdade, é possível encontrar um único momento nos anos de sua mocidade (mais precisamente entre os anos 1618-1619) em que esteve de fato

\footnotetext{
${ }^{20}$ Carta de Descartes a Elisabeth de novembro de 1643 (AT, IV, 47).
} 
envolvido na formulação silogística de uma demonstração. Não se tratava, todavia, de um texto de matemática pura. Seu tema é a mecânica dos fluidos e foi levado a cabo more geometrico: a partir da fixação de três princípios (praemissi) e a formatação das demonstrações num modelo, diríamos, estritamente lógico. A precisão de seu vocabulário é curiosamente reveladora: "que é assim através desse silogismo" (quod sit hoc syllogismo), "que se queria provar" (quod erat probandum $)^{21}$, e mostram um jovem Descartes que não se parece em nada com aquele que, nas Regras ou no Discurso, criticaria veementemente o formalismo silogístico.

Longe de buscar uma inconsistência entre o que prega nos escritos metodológicos e o que realmente faz na sua prática matemático-científica, esse desvio inicial perante as teses que se solidificarão em seus escritos vindouros deve ser considerado sob outra perspectiva. Com efeito, esse contraexemplo, ao invés de impor alguma dificuldade ao que foi dito acima, serve mais para endossar o quão esdrúxulo a nosso autor foi ter assumido um estilo que não lhe podemos atribuir ao longo de sua carreira matemática, tratando-se mais dum ponto fora da curva do que qualquer outra coisa. É possível que se tratasse mais bem de uma espécie de exercício que um procedimento usual do qual podemos extrair alguma tese geral sobre a metodologia cartesiana.

A crítica mais imediata e mais geral elaborada por Descartes contra o formalismo silogístico tem a ver com o grande número de preceitos que são utilizados pela lógica tradicional. Na silogística aristotélica são nada menos que 256 combinações de formas silogísticas possíveis das quais 24 são válidas. Além do mais, há uma série de regras como a de conversão (que invertem as posições de sujeito e predicado, podendo ser simples ou acidental) e a de redução ao absurdo. De fato, nada senão um grande contraste pode ser notado entre o número de regras da silogística tradicional e da metodologia cartesiana. Nas Regras e no Discurso, contam-se, respectivamente, 21 regras e 4 preceitos. Antes da formulação desses quatro preceitos, Descartes diz o seguinte: “ao invés desse grande número de

${ }^{21}$ Cf. Physico-mathematica (AT, X, 67-74). Ainda nesse mesmo escrito, há, contudo, uma passagem onde nosso autor, curiosamente, parece cogitar a possibilidade de reduzir a dedução científica a uma simples intuição, que será um tema tratado na primeira seção de trabalho. Ei-la, pois: "A [premissa] maior parece ser tão clara e evidente que poderia ser um princípio científico" (Major videtur esse tam clara \& evidens, ut possit esse principium scientificum) Cf. (AT, X, 70, 1. 25-26). 
preceitos de que a lógica é composta, eu cri que me bastariam os quatro seguintes", confirmando a sua preferência por um número reduzido de regras. ${ }^{22}$ Ainda noutro trecho das Regras, Descartes nos exorta a abandonar as regras da dialética: "omitamos todos os preceitos dos dialéticos" (omittamus omnia dialecticorum precepta), restando-nos apenas as do seu novo método. ${ }^{23}$

Contudo, isso deve ser entendido como uma consideração inicial e superficial sobre o formalismo silogístico. Afinal, Descartes apresenta outras críticas que o fazem promover um método diferente da lógica das escolas. Em primeiro lugar, apesar de falar sobre os primeiros princípios no contexto fundacional das Regras, relacionando-os ao ato intelectivo intuitivo, Descartes não lhes dá qualquer papel especial na sua prática matemática. No início da segunda meditação frente à pergunta: "O que é um homem? Acaso, direi animal racional?" (Sed quid est homo? Dicamne animal rationale?). ${ }^{24}$ Descartes rejeita a resposta e elabora uma resposta de caráter metodológico. Com efeito, ele acaba por censurar o emprego de uma definição aristotélica (gênero e diferença específica). Dito de outro modo, ele desafia o papel metodológico e, até mesmo, a utilidade dos princípios, como veremos.

Diferentemente de muitos dos matemáticos de sua época que buscavam a reelaboração de demonstrações euclidianas, não encontramos nos textos de Descartes nenhuma tentativa de reformulação dos princípios, sejam definições ou

${ }^{22}$ Cf. Discurso do método (AT, VI, 18, 1. 8-15).

${ }^{23}$ Cf. Regras para a direção do espírito (AT, X, 405, 1. 8-15) Convém aqui fazer uma consideração sobre o que Descartes entende por lógica e dialética. Não é de todo claro o sentido de lógica adotado por Descartes. Às vezes, ele à chama de "dialética", "dialética ordinária" ou "lógica das escolas". Em sua conversação com o jovem holandês Frans Burman, encontramos um breve comentário quanto à sua crítica a respeito da lógica no Discurso do Método (isto é, de que ela serviria para falar sem julgamento de coisas que ignoramos, tal como a arte de Lúlio). Como é relatado por Burman: Ea potius est dialectica, cum doceat nos de omnibus rebus disserere, quam Logica, quae de omnibus rebus demonstrationes dat: et sic bonam mentem magis evertit quam adstruit, nam dum nos divertit et digredi facit in hos locos communes et capita, quae rei externa sunt, divertit nos ab ipsa rei natura. Correspondência (AT, V, 175). Tratara-se mais precisamente de uma crítica à dialética, e não exatamente à lógica. Pois, se, por um lado, a dialética "nos ensina a falar sobre todas as coisas", a lógica "permite alcançar em todas as questões uma verdade demonstrada". Porém, mesmo que essa distinção seja elucidativa, entretanto em ambas opera a utilização ilegítima da silogística ora na dialética como uma articulação irrefletida de palavras, ora no que Descartes chama de lógica como uma técnica simplesmente expositiva, ou explicativa, mas sem nenhuma virtude na descoberta ou invenção de novas verdades. Em ambos casos, não se obtém conhecimento por motivos diferentes: no primeiro, porque os termos encadeados num argumento silogístico podem ser vazios ou desprovidos de sentido, e, no segundo, simplesmente não se alcança novas verdades, sendo apenas uma forma de apresentação de proposições já conhecidas.

${ }^{24}$ Cf. Meditações Metafísicas (AT, VII, 25, 1. 26-27). 
axiomas. Nosso autor, pelo contrário, reduz os princípios a uma total inutilidade. Não compactuando com uma visão axiomática da geometria, Descartes não só rejeita um estilo demonstrativo como também não faz nenhum uso de princípios, ao menos explicitamente em sua geometria. O que notamos assim que começamos a leitura d'A Geometria é que ela não busca partir suas demonstrações de um número rígido ou pré-estabelecido de princípios, não havendo, portanto, noçõescomuns, definições nem postulados no início do texto, como o fez Euclides.

Somente encontramos n'A Geometria um breve comentário sobre a função dos postulados. E, no entanto, sem causar nenhum tipo de surpresa, Descartes insiste numa perspectiva que os consideraria meramente nominais por assim dizer. Isto é, não lhes confere nenhum valor na determinação das figuras matemáticas, como também o observou Casanave. ${ }^{25}$ Dito de outro modo, as definições ou postulados não são capazes de identificar com precisão os diferentes objetos da geometria. Ademais, deixa implícita a possibilidade de haver definições de figuras que não são legitimamente geométricas. Seu novo critério de definição ou de construção dos objetos matemáticos parece ser a tradução do objeto geométrico em uma equação algébrica, a qual, dependendo do seu grau, pode ser então classificada segundo seu gênero. Vejamos seu comentário:

\begin{abstract}
Eu não diria também que isso seja porque eles não tivessem quisto aumentar o número de seus postulados, e que eles se contentassem com se estivessem acordado que eles pudessem ligar dois pontos dados por uma linha reta, e descrever um círculo a partir de um centro dado que passasse por um ponto dado; pois eles não hesitaram em supor, ao tratar das secções cônicas, que se pudesse cortar todo cone dado por um plano dado. E não é preciso supor nada para traçar todas as linhas curvas que eu pretendo introduzir aqui, senão que duas ou muitas linhas pudessem ser movidas uma pela outra, e que suas intersecções formam outras linhas; o que não me parece difícil. É verdade que nem todos eles aceitaram as secções cônicas em sua geometria, e eu não quero começar a mudar os nomes que foram aprovados pelo uso [...]. (GRIFO NOSSO) ${ }^{26}$
\end{abstract}

\footnotetext{
${ }^{25}$ Casanave comenta o fato de Descartes desprezar a axiomática. Cf. CASANAVE, a ser publicado, p. 59.

${ }^{26}$ No original: Je ne dirai pas aussi que ce soit à cause qu'ils n'ont pas voulu augmenter le nombre de leurs demandes, et qu'ils se sont contentés qu'on leur accordât qu'ils pussent joindre deux points donnés par une ligner droite, et décrire un cercle d'un centre donné, qui passât par un
} 
O contexto em que se desenrola o seu comentário é o de redefinição dos objetos que podem ser considerados geométricos e aqueles que não o são (chamados de mecânicos). Descartes revisa o que ele entende como uma distinção clássica e introduz novos objetos no rol dos geométricos. Ao se interrogar sobre as causas que levaram os matemáticos antigos a excluírem determinadas figuras do grupo de objetos legitimamente geométricos, ele responde dizendo que não foi devido à falta de postulados. Não foi, então, por quererem preservar apenas dois postulados euclidianos, a saber: os postulados euclidianos I.1, que permite a construção de linhas retas ("ligar dois pontos dados por uma linha reta"), e I.3, que permite a construção de círculos (“descrever um círculo a partir de um centro dado que passasse por um ponto dado"). ${ }^{27}$ Afinal, esses geômetras também introduziram um postado geral que autoriza a construção de secções cônicas: "cortar todo cone dado por um plano dado". ${ }^{28}$ Logo, não haveria nenhuma razão para introduzirem um novo postulado capaz de construir novas figuras geométricas.

Ao fim desse comentário, Descartes conclui que não é preciso postular a construção dos objetos geométricos que ele pretende acrescentar ao cânone clássico. Ou seja, os postulados ou suposições que autorizam a construção de figuras geométricas não desempenham nenhum papel na geometria cartesiana. Por essa razão, ele diz não se tratar simplesmente de uma mera alteração de nomes. Uma mudança dos princípios, sejam definições ou postulados, não é suficiente para promover a transformação que ele propõe. Desse modo, Descartes introduzirá um novo modelo de demarcação entre objetos geométricos e mecânicos, que não será tratado nesse texto, uma vez que devemos focalizar o projeto metodológico de Descartes, sem adentrar a fundo as questões de sua geometria. Contudo, o que é preciso marcar aqui é a sua rejeição à utilidade metodológica dos princípios.

point donné ; car ils n'ont point fait de scrupule de supposer outre cela, pour traiter des sections coniques, qu'on pût couper tout cône donné par un plan donné. Et il n'est besoin de rien supposer pour tracer toutes les lignes courbes que je prétends ici d'introduire, sinon que deux ou plusieurs lignes puissent être mues l'une par l'autre, et que leurs intersections en marquent d'autres; ce qui ne me paraît en rien plus difficile. Il est vrai qu'ils n'ont pas aussi entièrement reçu les sections coniques en leur géométrie, et je ne veux pas entreprendre de changer les noms qui ont été approuvés par l'usage [...]. A Geometria (AT, VI, 398).

${ }^{27} \mathrm{Na}$ tradução latina de Florimond de Beaune: “[...] data duo punta rectâ conjungere lineâ, atque ex dato centro circulum describere [...]". Cf. VAN SCHOOTEN, 1649, p. 20.

${ }^{28}$ Ibidem. "[...] datum Conum dato plano secare". 
É preciso, contudo, fazer uma breve consideração. Isso não significa que Descartes desaprovasse ou rejeitasse os princípios do corpus tradicional. Sua atitude não deve ser compreendida como uma contestação à solidez ou firmeza dos princípios da geometria clássica, que não são por acaso enfatizadas na primeira parte do Discurso e são ademais evocados algumas vezes nos seus textos de matemática, ainda que implicitamente. ${ }^{29}$ Descartes não busca indicar um conjunto de princípios do quais pretende demonstrar todas as provas de sua geometria. Porém, frente à necessidade de utilizá-los, ele os evoca.

A crítica cartesiana ao formalismo silogístico não se reduz às suas considerações acerca do papel dos princípios nem ao arranjo das faculdades. Seu ataque é, sobretudo, contra as "formas silogísticas" (syllogismorum formae), e pode sê-lo lido particularmente nas Regras. Todavia, não faz jamais objeções à validez formal das inferências. Ao contrário, no Discurso, por exemplo, chega a elogiar alguns dos preceitos da lógica, descrevendo-os como "muito verdadeiros e muito bons", ainda que outros sejam "nocivos ou supérfluos". ${ }^{30}$ De modo semelhante, na sétima parte das Objeções e Respostas, Descartes chega a dizer explicitamente: "eu não reprovo os silogismos, e nem mesmo corrompo suas formas, já que eu sempre me utilizei deles em meus escritos quando precisei”. ${ }^{31}$ Assim, a crítica de Descartes jamais se direciona à validade dos silogismos, pois ele mesmo admite a sua utilização em alguns momentos.

Descartes, no Discurso do Método, explica que os silogismos nos levam "a falar sem julgamento daquelas [coisas] que se ignoram", operando maquinalmente tal "como a arte de Lúlio" 32 . Igualmente nos Princípios de Filosofia, a lógica ensinada nas escolas serve para falar de algo sem julgamento, isto é, uma articulação irrefletida de palavras sentido e que não emprega a nossa faculdade encarregada da distinção do verdadeiro e do falso, a razão. A validade das formas silogísticas funciona independentemente de seu conteúdo. ${ }^{33}$ Assim, quando

\footnotetext{
${ }^{29}$ Discurso do método (AT, VI, 7, 1. 24-30).

${ }^{30}$ Discurso do método (AT, VI, 17, 1. 21-24).

31 No original: Eàdemque ratione, me non improbare syllogismos, nec earu veterem formam detrupare, satis juficant mea scripta, in quibus semper iis usus sum, cùm fuit opus. Sétimas Respostas (AT, VII, 544).

${ }^{32}$ Raimundo Lúlio, filósofo do século XIII, inventou discos subdivididos em câmaras contendo cada uma um atributo divino e que se combinam por uma rede de triangulações, a fim de obter conhecimento acerca da Trindade.

${ }^{33}$ Cf. GILSON, 1967, p. 184.
} 
seguimos estritamente regras da lógica de modo irrefletido, elas passam a operar automaticamente sem o suporte cognitivo da razão. Contudo, apesar dessa crítica que envolve as faculdades (e, por isso, psicológica), Descartes elabora outra de ordem puramente metodológica. Vejamo-la.

A sua crítica dirige-se, antes de tudo, ao emprego metodológico dessas inferências. Com efeito, o núcleo de sua censura é a utilidade metodológica dos silogismos, e não à sua estrutura lógica. Frequentemente, a lógica, ou dialética vulgar, é chamada de inútil. Sua suposta inutilidade é, contudo, identificada à sua incapacidade de descobrir novas verdades. Sempre que se refere aos aspectos negativos da lógica, Descartes o faz contrapondo à investigação, percepção ou conhecimento da verdade, que escapa ao encadeamento silogístico e que só é alcançada através de seu método. Assim, não se trata da validade das formas lógicas, mas de sua eficácia no campo da metodologia científica.

Contudo, é preciso ainda entender de que modo Descartes sustenta a sua crítica ao formalismo silogístico. De fato, a verdade da conclusão depende logicamente das premissas, e ninguém o negaria. Porém, do ponto de vista da ordem da descoberta científica, a conclusão deve ser alcançada antes. Assim, a ciência demonstrativa (de origem aristotélica, e que foi cultivada nas universidades no tempo de Descartes) propõe a estruturação do argumento científico, mas tal estruturação depende, por sua vez, da verdade da proposição posta na conclusão. Noutras palavras, a arrumação da justificação científica pressupõe a verdade da conclusão.

Existe, assim, uma diferença entre a justificação e a descoberta científica. O que busca Descartes não é um método de justificação, mas um método capaz de alcançar novas verdades científicas. E ao fazer essa distinção, julgava que o único benefício que se pode tirar do formalismo silogístico é a apresentação ou exposição dos argumentos. Por isso mesmo, Descartes reconhece um papel expositivo, explicativo ou, quando muito, persuasivo, da demonstração através de silogismos. Embora não sirvam à descoberta de verdades científicas, as formas silogísticas são úteis "para expor mais facilmente as razões raciocínios já 
conhecidos" (ad rationes jam cognitas facilius exponendas). ${ }^{34}$ Por conseguinte, Descartes considera que a exposição silogística não deveria ser considerada como uma das partes da filosofia, mas da retórica, que lida justamente com a exposição dos argumentos.

Enquanto na silogística tradicional cabe distinguir os dois termos extremos (ou termos maior e menor) e o termo médio, além de como eles se organizam no arranjo do silogismo, Descartes propõe como proceder na investigação de novas verdades a partir de seu método. Como foi visto no primeiro capítulo com o exemplo apresentado pelo próprio Aristóteles, o que distingue uma demonstração científica (ou seja, capaz de apresentar o porquê, a causa) de uma demonstração defeituosa (ou seja, que não apresenta o porquê, e, sim, o que) é a organização dos termos envolvidos. O que está próximo da Terra não cintila. Decidir em que posição da figura do silogismo se encontra o termo médio, “o que não está próximo da Terra", é uma das tarefas da metodologia aristotélica. Contudo, nessa mesma prática, já sabemos de antemão quais são os termos do silogismo. Descartes a condena, afinal, na prática científico-matemática, onde se busca a descoberta de novas verdades, não se tem previamente os termos envolvidos. Diferentemente do silogismo, que parte já do conhecimento da verdade da conclusão, a situação que nós não sabemos a verdade da proposição, Descartes chama de questão (quaestio). Toda investigação é investigação de uma questão. E por questões entende o seguinte: "tudo em que se encontra ou o verdadeiro ou o falso". ${ }^{35}$ Assim, o processo de investigação científica parte do não conhecimento de algo.

Descartes descreve os passos a serem seguidos quando estamos diante de uma questão. Diferentemente do procedimento aristotélico, os termos não estão previamente apresentados ou dispostos numa forma silogística. Em primeiro lugar, deve-se reconhecer que há algo de desconhecido (aliquid esse ignotum) e que é a motivação da investigação. Em seguida, o que é desconhecido deve ser designado (designatum), permitindo que seja distinguido de outras coisas. E, por

\footnotetext{
${ }^{34}$ Cf. Regras para a direção do espírito (AT, X, 406, 1. 23-24). Noutra passagem diz: “[...] para a Lógica, seus silogismos e a maior parte de suas instruções servem para explicar a outrem as coisas já sabidas". Discurso do Método (AT, VI, 17, 1.16-19).

${ }^{35}$ Regras para a direção do espírito (AT, X, 432, 1. 13-15).
} 
fim, deve ser designado a partir do conjunto de relações de outras coisas já conhecidas (per aliud quid quod sit cognitum). ${ }^{36}$

Com efeito, sua censura ao formalismo silogístico guarda algo de comum com a sua outra crítica à geometria sintética tradicional. Durante muito tempo, a obra euclidiana (modelo legítimo de geometria sintética) foi pensada como uma ilustração da metodologia aristotélica, isto é, fundada nos silogismos científicos. Mas, embora muitos comentadores tenham contemplado uma relação estreita entre a prática matemática de Euclides e a discussão metodológica de Aristóteles (incarnada nos Segundos Analíticos), sabemos hoje que há uma grande diferença entre as duas perspectivas. Aristóteles advogada uma perspectiva lógica, por assim dizer. Afinal, ele compreendia as demonstrações científicas a partir de silogismos cuja causa é apresentada pelas premissas (ou seja, provas homogêneas, sem qualquer apelo a recursos diagramáticos). Euclides, por outro lado, serve-se de recursos lógicos mas também diagramáticos. Suas provas são, então, heterogêneas, porque não dependem exclusivamente dos passos linguísticos da demonstração.

É natural, portanto, que Descartes não distinguisse um do outro. Aliás, como já vimos, houve não poucos matemáticos que, frente às dificuldades de conciliar os dois projetos, o euclidiano e o aristotélico, se esforçaram ainda mais em garantir essa relação nas suas reconstruções de provas euclidianas. Ademais, é um fato inegável que Descartes também aceitasse o corpus tradicional da matemática clássica, como bem observa Jullien. ${ }^{37}$ Ou seja, não se trata de uma crítica à geometria clássica devido a erros contidos no interior de suas demonstrações. Descartes não as considera incorretas, e ipso facto não proporá a reformulação de princípios nem a revisitação de demonstrações dos geômetras clássicos. Até porque uma nova elaboração das demonstrações euclidianas sob os padrões da silogística e que fossem ainda mais rigorosos não alcançaria a prioridade desejada por Descartes, isto é, a descoberta de novas verdades. Ademais, como poderá ser visto no terceiro capítulo desse texto, Descartes apresenta uma crítica aos matemáticos que, diante de problemas a serem

\footnotetext{
${ }^{36}$ Regras para a direção do espírito (AT, X, 430, 1. 17-22).

37 Jullien explica que Descartes aceitava o corpus tradicional das matemáticas. Cf. JULLIEN, 1996, p. 8-10.
} 
resolvidos, recorrem às demonstrações euclidianas e tentam resolvê-los tão somente por passos que remetam aos princípios e aos teoremas (e problemas) euclidianos, a fim de lhes conferir algum tipo de dignidade às suas demonstrações.

Retomemos, enfim, o que havíamos dito. Descartes parece vincular a sua crítica ao formalismo silogístico com aquele que faz também à geometria sintética. A matemática cartesiana se pretende, ao mesmo tempo, como a antítese do formalismo lógico e da geometria sintética. Porém, de que modo Descartes as associa? São nas Objeções e Respostas onde torna mais clara essa associação. Em primeiro lugar, as demonstrações da geometria sintética estabelecem de princípios, os quais legitimam cada passo demonstrativo. Partindo de uma longa série de princípios (que são: definições, postulados e axiomas) e servindo-se de proposições provadas anteriormente (que são teoremas e problemas), esses geômetras buscavam demonstrar uma conclusão, que se seguiria desses pressupostos anteriores. Assim, os geômetras sintéticos, diferentemente do que é feito por Descartes, "pressupõe noções primeiras para demonstrar as coisas geométricas" (quod primae notiones ad res Geometricas demonstrandas praesupponuntur). ${ }^{38}$ Todavia, como já foi visto no início desse capítulo, Descartes critica a utilidade metodológica dos princípios e, portanto, não os utiliza nas suas demonstrações.

Contudo, a associação entre formalismo silogístico e a geometria sintética não se reduz a uma crítica à sistematização axiomática. O que há de comum entre as formas dos silogismos e a maneira sintética de demonstrar é a ineficácia metodológica para descobrir novas verdades. Ainda nas Objeções e Respostas, Descartes elabora também um comentário sobre o modo geométrico de escrever (modo scribendi geometrico), no qual ele distingue duas partes, a saber: ordem (ordo) e a maneira de demonstrar (ratio demonstrandi). A primeira consiste na organização da dependência dos passos da demonstração. Ou seja, a ordem estabelece que as primeiras coisas propostas devam ser conhecidas sem ajuda das seguintes e que as coisas que venham em seguida sejam demonstradas pelas

\footnotetext{
${ }^{38}$ Cf. Segundas Respostas (AT, VII, 156, 1. 27-28).
} 
anteriores. A maneira de demonstrar é dúplice: analítica e sintética. Essa última é a que de fato melhor descreve a metodologia dos geômetras sintéticos. ${ }^{39}$

Segundo nosso autor, somente a análise mostra a verdadeira via pela qual podemos descobrir novas verdades de maneira metódica. Com efeito, a análise é a verdadeira arte de descoberta (ars inveniendi). A síntese é, no entanto, uma via expositiva, sendo útil ao aprendizado. Enquanto a análise busca novos resultados, a síntese, que está mais de acordo com a atividade pedagógica, apenas os expõe. E por isso mesmo padece do mesmo mal que o formalismo silogístico, a ineficácia metodológica de não ser capaz de descobrir novas verdades. A síntese é antecedida por um procedimento metodológico muito mais eficaz, a análise, que descobre novas verdades. De modo semelhante às formas dos silogismos, a síntese pressupõe a verdade da conclusão, não servindo assim senão como uma forma de exposição dos resultados já obtidos por via analítica. ${ }^{40}$

Em seguida, acrescenta ainda que os geômetras antigos se serviam somente da síntese em seus escritos, não porque ignorassem a análise, mas porque queriam guardá-la em segredo. Tendo descoberto as verdades matemáticas por via analítica, expunham-nas somente por via sintética. Também nas Regras, já havia tecido o mesmo comentário. Lá ele diz que os antigos geômetras resolviam todos os problemas matemáticos por meio da análise, mas que a escondiam às gerações posteriores. Insatisfeito com a metodologia sintética, Descartes atribui a seu próprio método científico-matemático as virtudes necessárias para ultrapassar os antigos e comprovar uma maior aptidão resolvendo problemas que restavam sem solução desde a Antiguidade.

${ }^{39}$ Cf. Segundas Respostas (AT, VII, 155).

${ }^{40}$ Cf. Segundas Respostas (AT, VII, 156). 


\section{Intuição: a ferramenta metodológica}

\section{1}

\section{Introdução}

No capítulo anterior, ficou representado de modo esquemático um dos grandes debates metodológicos da época no campo das matemáticas. Descartes não participou dele ativamente. Ao contrário, como vimos na última seção do capítulo primeiro, Descartes se distancia não só da colocação do problema inicial como também das propostas de redução silogística. De modo geral, podemos dizer que o modelo metodológico de Descartes para as matemáticas é uma antítese de ambos os projetos. Afinal, os dois projetos estão estruturados numa concepção de ciência aristotélica, que não era de nenhum modo compartilhado por Descartes.

Alguns autores enfatizaram a emergência do simbolismo algébrico nas suas demonstrações matemáticas e a sua valorização do método de análise. Nesse capítulo, propomos a investigação da noção de intuição e sua relação com elementos centrais na concepção de prova matemática, como princípios e deduções. Boa parte dos comentadores que a abordaram, circunscreveram a intuição a um problema puramente fundacional. Não queremos, todavia, negar esse aspecto, mas apenas realçar uma dimensão por vezes esquecida: encontrar o papel desempenhado pela intuição da prova matemática. Ou seja, além do campo meramente fundacional, é possível atribuir à intuição algum tipo de papel que se reflete no seu modo de proceder nas matemáticas ou que autorize algum tipo de procedimento demonstrativo?

Além do mais, a intuição, que trava confronto com o formalismo silogístico, exemplificado no começo do capítulo anterior, ecoa em quais momentos da sua geometria? Dedicamos justamente uma parte desse capítulo a revisitar algumas passagens n'A Geometria, o mais das vezes sequer mencionadas pelos especialistas, em que a intuição é evocada. O emprego da intuição nessa 
obra parece reforçar e destoar por vezes dos textos tradicionalmente visitados no estudo desse tema.

\section{2}

\section{A intuição}

É na regra III das Regras para a direção do espírito que Descartes desenvolve de modo mais claro o que entende por intuição. ${ }^{41}$ Inicialmente, explica que há dois atos do nosso intelecto (intellectus nostri actiones) que nos fazem evitar o erro e nos direcionam no caminho da certeza e da ciência, são eles: intuição (intuitus) e dedução (deductio). A intuição, Descartes a define (duplamente, conforme a observação de Marion ${ }^{42}$ : "que também é", quod idem est) do seguinte modo:

\section{A concepção tão fácil e tão distinta (tam facilem distinctumque conceptum)} duma mente pura e atenta (mentis purae \& attentae) que dela, precisamente, não resta nenhuma dúvida que a entendemos (ut de eo, quod intelligimus, nulla prorsus dubitatio relinquatur). ${ }^{43}$

2. A concepção indubitável (non dubium conceptum) duma mente pura e atenta (mentis purae \& attentae), que nasce somente da luz da razão (qui à solà rationis

\footnotetext{
${ }^{41}$ A tese de um conhecimento inato, puramente intelectivo, imediato e não empírico perpassa toda a filosofia cartesiana, sendo-lhe uma marca permanente. Queremos dizer com isso que a intuição não é registrada somente nos primeiros escritos cartesianos, como nas Regras, mas também noutros textos maduros de Descartes. Nas Meditações, por exemplo, ela parece em diversas passagens, mas que podem passar desapercebidas, devido à tradução francesa, que a verteu por outros termos. Desmond Clarke chegou a afirmar que a intuição reaparece na segunda meditação sob o nome de inspeção da mente (inspectio mentis), figurando um importante papel no caso do pedaço de cera. Cf. CLARKE, 1982, p. 58. Contudo, parece mais apropriada a posição de van de Pitte, o qual rejeita a correspondência entre intuição e inspeção, porque esta pode ser imperfeita e confusa ou clara e distinta, enquanto aquela só pode ser clara e distinta. Cf. VAN DE PITTE, 1988, p. 455. Apesar de van de Pitte discordar pontualmente da aproximação feita entre a inspeção da mente e a intuição, é impossível negar que, mesmo depois das Regras, a intuição continue ser uma tese legitimamente cartesiana. Ademais, a intuição da mente (ou luz natural) é ainda evocada na Segunda Resposta, onde Descartes explica que o "eu penso, logo sou, ou existo" não se trata de um silogismo ou dedução, mas de algo que é intuído. Já nos últimos textos, encontramo-la n'A Procura da verdade e em uma carta, provavelmente destinada ao Marquês de Newcatle, onde se serve da noção de intuição para explicar a visão beatífica. Todavia, longe de considerá-la uma doutrina estanque, pretendemo-nos fixar, sobretudo, nos textos metodológicos. Esses, sim, podem ser fundamentais na compreensão da matemática cartesiana. A menção, por exemplo, à visão beatífica não é de nenhum modo fundamental na argumentação do presente texto.

${ }^{42}$ Cf. MARION, 1993, p. 47-48.

${ }^{43}$ Regras para a direção do espírito (AT, X, 368, 1. 15-17).
} 
luce nascitur) e é mais certa que a própria dedução, pois é mais simples (\& ipsàmet deductione certior est, quia simplicior). ${ }^{44}$

Acrescento, aqui, ademais, que, para além da dupla definição, há o que poderíamos chamar, por assim dizer, duma dupla definição negativa que a precede, a qual elucida que a intuição é tanto alheia a qualquer influência dos sentidos ("não é a crença flutuante dos sentidos": non fluctuantem sensuum fidem) como também à imaginação ("nem o juízo falaz da imaginação que mal compõe": vel malè componentis imaginationis judicium fallax). ${ }^{45}$

Marion observa ainda que em ambas a definições está presente a faculdade mobilizada (mens) e a representação em jogo (conceptus). Contudo, convém observar aqui que há uma dupla insistência para evitar a dúvida (nulla dubitation relinquatur; non dubium conceptum). ${ }^{46} \mathrm{Na}$ realidade, a eliminação da dúvida tem a ver com uma preocupação particular e uma distinção implícita em cada definição: primeiramente, em relação à operação do ato intelectual que causa o desaparecimento da dúvida, enquanto que a segunda revela o resultado produzido por essa operação, que não é senão uma representação livre de qualquer tipo de dúvida.

O fato de ter excluído a dúvida explica-se pela apreensão do intelecto puro. A pureza da faculdade impede a intervenção de outras faculdades que podem ser fonte de algum tipo de falsidade, especialmente as supracitadas imaginação e sentidos. Mas, além da pureza, a faculdade é associada a outra característica: o de estar atenta. A atenção é uma das propriedades ligadas, sobretudo, ao intelecto. Isso significa que a representação em jogo deve ser acessada pelo intelecto ao momento da intuição. Essa decisão impede, por outro lado, que a representação seja transferida à memória. Ao fim da segunda definição, é evidente que a ação solitária do intelecto, pois ele diz que a o conceito nasce somente da luz da razão (a sola rationis luce).

\footnotetext{
${ }^{44}$ Regras para a direção do espírito (AT, X, 368, 1. 18-20).

${ }^{45}$ Regras para a direção do espírito (AT, X, 368, 1. 13-15). Apesar desse comentário, que separa a intuição dos sentidos e da imaginação. Na regra XII, Descartes analisa o papel da cada função das nossas quatro faculdades (entendimento puro, imaginação, memória e sentidos) e reconhece que elas podem ajudar ou atrapalhar (juvari posse vel impediri). Afinal, é, segundo ele, um papel do método demarcar os limites de cada uma delas. Cf. Regras para a direção do espírito (AT, X, 398, 1. 28).

${ }^{46}$ Cf. MARION, 1993, p. 48.
} 
Ademais, é preciso notar que a intuição está isenta dos erros dos sentidos e da imaginação e, além do mais, que Descartes a atribui um tipo de infalibilidade. Com efeito, não podemos mal executá-la (ab homine male fieri non posse). Nessa afirmação é dada ainda uma característica de universalidade à intuição, uma vez que todos os homens têm a faculdade de apreender os objetos da intuição com uma certeza absoluta. É o que se vê mais claramente na frase que encerra a definição da intuição: “Assim, qualquer um pode intuir com o espírito." Os homens, isto é, qualquer um de nós, podem apreender os objetos da intuição com a mesma objetividade e sem as marcas de uma experiência corrompida pelas inclinações subjetivas.

\section{3}

\section{Intuição e primeiros princípios}

Os objetos da intuição são apresentados, fundamentalmente na regra III, como primeiros princípios (prima principia). ${ }^{47} \mathrm{E}$ revivendo de algum modo o legado aristotélico, a tais princípios são atribuídos algumas características lógicoepistemológicas, a saber: o de serem verdadeiros (vera), mais simples (simpliciores), mais certos (certiores), conhecidos por si (nota per se), não podem ser deduzidos imediatamente (non immediate deduci). ${ }^{48}$ Ainda que se possa facilmente ver um paralelo entre essas características e aquelas dos primeiros princípios aristotélicos (verdadeiros, mais conhecidos...), não se encontra no texto cartesiano a característica mais importante para a noção de ciência demonstrativa: a de causalidade. Com efeito, os primeiros princípios cartesianos não são causais. Isso se dá porque Descartes assume outra perspectiva de ciência. Como ele sustenta no início das Regras, toda ciência é um conhecimento certo e evidente, sem evocar a noção de causalidade. ${ }^{49}$

\footnotetext{
${ }^{47}$ Regras para a direção do espírito (AT, X, 370, 1. 13).

${ }^{48} \mathrm{Cf}$. Regras para a direção do espírito (AT, X, 368), (AT, X, 387), (AT, X, 407).

${ }^{49}$ No original: Omnis scientia est cognitio certa et evidens. Cf. Regras para a direção do espírito (AT, X, 362, 1. 5). Comparar com o comentário do primeiro capítulo às características dos primeiros princípios aristotélicos (a saber: verdadeiros, primeiros, anteriores, imediatos, mais conhecidos, causais) e o comentário de Pereyra acerca da cientificidade das matemáticas. Este, como bom aristotélico, advoga que saber algo é conhecer a sua causa. Além do mais, como bem observou Mehl, Beeckman distinguia entre razão (ratio) e causa (causa). A causa estaria nas coisas, enquanto a ratio, na argumentação e nos princípios, como os axiomas. É provável,
} 
Além das velhas características dos primeiros princípios herdados, por assim dizer, da ciência demonstrativa aristotélica, convém também adicionar duas características cartesianas por excelência, a saber: de serem compreendidas clara e distintamente e simultaneamente e não sucessivamente (clare et distincte [...] tota simul et non successive intelligatur). ${ }^{50}$ Por outro lado, é preciso também enfatizar que a simultaneidade e a clareza e distinção não são critérios estritamente lógicos nem metodológicos, mas psicológicos. Por fim, chegamos a uma conclusão: uma proposição que não preencha os critérios mencionados acima não pode ser considerada um primeiro princípio cartesiano.

Quais seriam esses primeiros princípios cartesianos? Descartes enumera uma pequena lista sem propor nenhum tipo de hierarquia nem classificação, mas podemos dividir da seguinte maneira: os princípios da metafísica cartesiana e outros que são matemáticos. Os primeiros podem ser ilustrados assim: "que se pensa" (se cogitare) e "que se existe" (se existere). Os princípios da matemática são definições geométricas: a definição de triângulo "que o triângulo é delimitado por apenas três linhas" (triangulum terminari tribus lineis tantum) e o que parece ser uma variação da definição de diâmetro da esfera "que a esfera é limitada por uma única superfície" (globum unica superficie). ${ }^{51}$

Marion desenvolve uma explicação acerca dos princípios metafísicos, pois encontra neles uma particularidade, isto é: a reflexividade. ${ }^{52}$ Com efeito, os objetos desses princípios não são senão eles-mesmos, o que é marcado pelo reflexivo "se...". A reflexividade caracteriza a forma mesma da experiência como objeto, excluindo qualquer tipo de exterioridade material. Esse mecanismo da metafísica cartesiana que opera pelo puro entendimento dá a esses princípios uma maior facilidade, segundo a interpretação de Marion. Todavia, deixemos os princípios metafísicos de lado e concentremo-nos na relação dos princípios matemáticos com a intuição.

portanto, que Descartes, sob a influência de Beeckman, também rejeitasse a atribuição de causalidade a princípios. Cf. MEHL, 2005, 490.

${ }^{50}$ Cf. Regras para a direção do espírito (AT, X, 368), (AT, X, 387) e (AT, X, 407).

${ }^{51}$ Tais definições podem ser cotejadas, respectivamente, com as definições euclidianas I.19 e XI.17. Na edição do comentário aos Elementos de Clavius, a definição de triângulo corresponde à definição XX do livro I.

${ }^{52}$ Cf. MARION, 1993, p. 50-51. 
Convém, antes de tudo, também enfatizar que os primeiros princípios guardam uma relação de exclusividade com a intuição. Com efeito, a primazia dos primeiros princípios é afirmada pelo próprio autor quando diz que esses princípios apenas podem ser acessados pela intuição (prima principia, per intuitum tantum). ${ }^{53}$. Ao fazer isso, ele garante a exclusividade e a total dependência cognitiva dos primeiros princípios (sejam matemáticos ou filosóficos) à intuição. Dito de outro modo, o acesso psicológico às proposições que são o ponto de partida de todo conhecimento humano encontra seu fundamento essencial e exclusivamente na intuição.

Os breves exemplos do autor, contudo, deixam dúvidas em relação ao tratamento de outros princípios da matemática clássica. Poderíamos com razão, portanto, nos perguntar se postulados e noções-comuns (ou axiomas) fariam parte desses princípios. Posteriormente, Descartes introduz, na regra XII, as naturezas simples (naturae simplicissimae). Igualmente alvos da intuição, as naturezas simples se dividem em: puramente intelectuais, puramente materiais e o que ele chama de "noções-comuns" (communes notiones). Quanto a essas últimas, Descartes explica que são como vínculos (quaedam vincula), pois relacionam naturezas simples. Para estas são, então, destacados dois exemplos de natureza matemática: "duas coisas iguais a uma terceira são iguais entre si" (quae sunt eadem uni tertio, sunt eadem inter se) e "igualmente duas coisas que não podem ser relacionadas do mesmo modo têm algo diverso entre si" (quae ad idem tertium eodem modo referri non possunt, aliquid etiam inter se habent diversum). ${ }^{54}$. Quanto ao primeiro, parece fazer alusão à noção-comum euclidiana I.1. Já o segundo parece uma variação das noções-comuns euclidianas I.4 e I.5. Do que podemos concluir que a intuição parece operar também sobre os axiomas da geometria clássica.

As noções-comuns são, segundo Descartes, como certos vínculos (vincula quaedam) entre as naturezas simples e exercem um papel de articulação entre os conceitos mais básicos da matemática. Essas noções-comuns seguem uma estrutura quase lógica, uma vez que são como regras que nos conduzem à certeza nos raciocínios. Mais precisamente, às noções-comuns são atribuídas duas

${ }^{53}$ Regras para a direção do espírito (AT, X, 370).

${ }^{54}$ Regras para a direção do espírito (AT, X, 419, 1. 26-29). 
funções: conjugar os elementos em jogo e de formulá-los em um raciocínio que nos permita uma conclusão derivada da combinação dos dois elementos anteriores (ad alias naturas simplices inter se conjuguendas, et quarum evidentia nititur quidquid ratiocinando concludimus). ${ }^{55}$ Essas duas particularidades as diferencia em comparação com as definições matemáticas, já mencionadas acima, porque estas dizem respeito unicamente aos objetos matemáticos, sem a possibilidade de articulá-los entre si. Poderíamos ainda nos perguntar se dentre esses princípios há outros de natureza lógica, como o princípio de não contradição ou de identidade.

Entretanto, como bem observa Marion, a lista dos princípios que são apreendidos pela intuição é deixada indefinida. ${ }^{56}$ Descartes não se preocupa em estabelecer um número fixo, definido e preciso desses princípios. Não raramente nas suas exposições seu catálogo de exemplos é finalizado por um vago e inquietante "e semelhantes" (et similia), como se essa lista se estendesse ainda mais e deixando em aberto os tipos de princípios que se encaixam nessa indeterminação. ${ }^{57}$ Acaso, por exemplo, estariam implicados também os princípios lógicos? Se nos mantivermos presos ao texto das Regras, teremos de nos contentar com a simples incerteza.

A posição cartesiana que deixa indefinido o número de princípios é posto em oposição com a de Aristóteles por Marion. Diferentemente da tese de Descartes, a aristotélica defende a necessidade de se reduzir os princípios de uma demonstração ao máximo. O especialista fundamenta sua argumentação a partir de um trecho da Metafísica. Entretanto, é, sobretudo, no contexto das considerações metodológicas dos Segundos Analíticos que Aristóteles desenvolve uma argumentação em favor da redução dos princípios. Em um capítulo que se dedica a provar a superioridade das proposições afirmativas no contexto da ciência demonstrativa:

\footnotetext{
Admitamos, com efeito, todas as outras características sendo mantidas, que a melhor demonstração é aquela que se dá a partir do menor número de postulados, de hipóteses, ou de premissas. Se, com efeito, essas proposições são conhecidas da mesma maneira, o
}

\footnotetext{
${ }^{55}$ Regras para a direção do espírito (AT, X, 419).

${ }^{56}$ Cf. MARION, 1993, p. 50-51.

${ }^{57}$ Regras para a direção do espírito (AT, X, 368 e 419).
} 
conhecimento se fará mais rápido pelas proposições menos numerosas, e é justamente isso que é preferível. ${ }^{58}$

Contudo, ao invés de uma restrição que ele impõe, trata-se, na verdade, de uma recomendação metodológica.

É verdade que Marion concentra a sua explicação na relação entre Descartes e Aristóteles sem nenhuma preocupação com a recepção dos textos lidos pelo filósofo. Assim, é possível que Descartes conhecesse a predileção aristotélica por um conjunto limitado de princípios e premissa? Não se pode afirmar com certeza, mas é bem provável que sim. E, como se verá ao longo do texto, outros autores defenderam conscientemente posição aristotélica. Por isso, é bem possível também que Descartes o fizesse conscientemente. No comentário dos Conimbricenses dos Segundos Analíticos, que fora utilizado nos cursos do Colégio de La Flèche na época de Descartes, encontramos as mesmas observações. Acompanhando a posição de Aristóteles, os jesuítas da Universidade de Coimbra identificavam a demonstração superior (praestantior) àquela feita através do menor número de proposições. ${ }^{59}$

Apesar da dificuldade de se interpretar o que Descartes pensava a respeito dos princípios, uma coisa é certa: tais princípios são, para Descartes, “muito mais numerosos" (quae longe plura sunt) do que as listas concisas apresentadas ao longo das Regras. ${ }^{60}$ De um ponto de vista estritamente prático, há uma consequência nas matemáticas se considerarmos a possibilidade de se intuir princípios tal como foi proposta por alguns matemáticos, a exemplo de Barrow, a saber: a facilidade de se introduzir uma quantidade ao menos numerosa de princípios em uma dada demonstração. Por outro lado, esse tipo tese vai de encontro ao que poderíamos chamar de minimização de princípios, isto é: a restrição do número de princípios tendo em vista um determinado sistema axiomático. Esse pressuposto, que se radica em Aristóteles e é rememorado na esteira do aristotelismo, estipula um conjunto mínimo e completo de princípios.

\footnotetext{
${ }^{58}$ Esse extrato foi traduzido do francês ao português. Cf. Segundos Analíticos I, 25, 86a 33-5.

${ }^{59}$ Cf. CONIMBRICENSIS, In universam Aristotelis Logicam Tomus Alter, 1604, p. 250.

${ }^{60}$ Cf. Regras para a direção do espírito (AT, X, 368) e JULLIEN, 1996, p. 487-493. Assim como Marion, Jullien também observa o fato de Descartes não buscar um número mínimo de princípios. Todavia, ele sustenta a sua posição a partir de um comentário de Descartes às verdades eternas nos Princípios de Filosofia.
} 
Malgrado a posição cartesiana, o preceito de minimização dos princípios foi seguido por matemáticos e figuras interessadas na reconstrução de teoremas euclidianos, como aponta Jullien. Dentre eles podemos citar a título de ilustração o matemático Roberval, que, no seu exercício inacabado de reconstrução de parte d'Os Elementos, elenca um conjunto de cinco regras a serem seguidas. A últimas delas trata justamente da redução do número dos princípios. “Alcança uma ciência tal perfeição, quando ela é a mais simples, fundando-se sobre o menor número de princípios evidentes e sem prova o tanto que se possa”, já admoestava Roberval. 61

Sob outra perspectiva, apesar da divergência com projetos como o de Roberval, a facilidade com que se admite a introdução de princípios parece favorecer alguns dos intentos, em alguma medida, daqueles que tentaram reconstruir as demonstrações euclidianas a partir da introdução de princípios que não estão explícitos no corpo inicial dos axiomas e postulados do sistema axiomático. Veja-se, por exemplo, o caso de Barrow, que assim o faz sem maiores problemas e que comentamos brevemente no primeiro capítulo desse texto. Afinal, que representaria a intuição de princípios senão a facilitação e legitimação da evocação destes nas provas? Essa evocação gratuita de princípios parece, porém, ser o fundamento da ideia de que as provas euclidianas estão abreviadas e de que podemos garantir a sua cientificidade através de demonstrações mais longas, onde se há a necessidade de acrescentar princípios externos do sistema euclidiano, mas que seriam perfeitamente razoáveis e sem serem contrários aos estabelecidos pelo matemático.

Convém, todavia, destacar que a posição cartesiana é substancialmente oposta àquela de minimização do conjunto de princípios, ilustrada acima por Roberval. Além do mais, não há dúvidas que Descartes não buscava a restrição do conjunto dos princípios. Muito pelo contrário, ele os considera justamente inumeráveis. Uma passagem dos Princípios de Filosofia parece confirmar essa tese. Descartes, ao falar lá das verdades eternas, chamadas por ele também de

${ }^{61}$ Cf. ROBERVAL, 1996, p. 65. No original: "Il en arrive cette perfection à une science qu'elle en est plus simple, étant fondée sur le moindre nombre de principes évidents et sans preuve qu'il se peut." Jullien estabelece um paralelo entre dois modelos intuicionistas de matemática. Todavia, ambos guardam uma série de diferenças. Por exemplo, ao invés de uma concepção intelectualista da intuição, Roberval desenvolve uma noção empírica da intuição. Além de uma série de diferenças analisadas minuciosamente por Jullien. 
"noções comuns" (notiones communes) ou "axiomas" (axiomata), diz-nos o seguinte: “[...] e inúmeros outros, que não podem ser enumerados facilmente, mas que não podem ser ignorados quando se apresenta a ocasião de pensá-los e não estamos cegados por nenhuns preconceitos." ${ }^{2}$ Embora a dificuldade de arrolá-los e de descobri-los, quando estamos diante deles, reconhecemo-los facilmente.

\section{4}

\section{Os falsos princípios}

É preciso ainda compreender os princípios que se opõem aos primeiros princípios. Esses falsos princípios não satisfazem às exigências mencionadas nos parágrafos acima (o de serem verdadeiros, certos, claros e distintos...). Ao longo do texto das Regras, Descartes nos fala brevemente da existência de princípios que são falsos, mal concebidos e repugnantes (obliqua et male concepta principia; repugnantia principia). ${ }^{63}$ Não se pode, portanto, conferir a esses princípios a mesma dignidade dos primeiros princípios.

Ainda que não os explique minuciosamente, Descartes oferece ao leitores alguns exemplos e algumas razões para que eles sejam excluídos da lista dos primeiros princípios. Os exemplos, contudo, são matemáticos, mais precisamente da geometria. Vejamos: "a linha, da qual se faz concebida a superfície através de um fluxo" (lineam, ex cujus fluxu superficiem fieri concipti) e ao ponto dos geômetras, quando eles compõem a linha a partir de seu movimento - ou, como uma linha, ou como um quadrado" (cum puncto Geometrarum, dum ex ejus fluxu lineam componunt, vel ut lineam quandam, vel ut quadratum). ${ }^{64}$ Trata-se das definições da doutrina do fluxo, que têm seu aparecimento na matemática antiga.

Desde a Antiguidade, havia discussões acerca dos princípios da geometria e da aritmética. Os matemáticos antigos buscavam encontrar as melhores formulações dos princípios matemáticos. É justamente nesse contexto de

\footnotetext{
${ }^{62}$ No original: [...] et alia innnumera, quae quidem omnia recenseri facile non possunt, sed nec etiam ignorari, cum ocurrit occasio ut de iis cogitemos, et nullis praejudiciis excaecamur. $\mathrm{Cf}$. Princípios de Filosofia XLIX (AT, VIII, 23-24).

${ }^{63}$ Cf. Literalmente: obliquis et male conceptis principiis (AT, 442, 1. 15), repugnantibus principiis (AT, 446, 1. 20).

${ }^{64}$ Regras para a direção do espírito (AT, X, 446 e 450). As definições da doutrina do fluxo são também rejeitadas no capítulo VII d'O Mundo (AT, XI, 39).
} 
reformulação das definições da geometria que nasceu a doutrina do fluxo. As primeiras referências a essa doutrina, estão já em Aristóteles e Proclo, o qual buscava definir a linha como um fluxo do ponto, a superfície como um fluxo da linha e, por fim, o sólido como o fluxo da superfície. Essas definições não foram muito utilizadas pelos matemáticos, uma vez que não há nenhum ganho do ponto de vista prático. Contudo, elas foram aceitas e bastante discutidas por aqueles que tentaram explicar nosso acesso aos objetos matemáticos.

Como Descartes tomou conhecimento das definições da doutrina do fluxo? Além das citações ao comentário dos Conimbricenses do De anima, essas teses estavam de algum modo difundidas entre os matemáticos dos séculos XVI e XVII graças ao comentário de Clavius aos Elementos, de Euclides. Este jesuíta dedicou alguuns comentários a essas definições em sua obra, nomeadamente: as definições da linha (definitio II), da linha reta (definitio IV), da superfície (definitio $V$ ), da superfície plana (definitio VII) e, curiosamente, o postulado da construção de uma linha reta entre dois pontos (petitio vel postulatum I). ${ }^{65}$ Ainda que não sustente a doutrina do fluxo, Clavius a explica enfatizando o papel cognitivo da imaginação na composição dessas definições. ${ }^{66}$

Dito isso, por que então Descartes rejeitava essas definições? Com efeito, a imaginação é a faculdade que permite a descrição do fluxo por meio de um movimento. Esse movimento, por outro lado, é puramente imaginativo, e não intelectual. Estando de acordo com o que havia dito antes acerca da distinção entre a representação puramente intelectual e aquela composta pela imaginação (vide a definição de intuição), Descartes pensa que os objetos por excelência da intuição, os primeiros princípios, devem estar preservados dos erros da imaginação. E uma vez que a imaginação é o suporte cognitivo das definições da doutrina do fluxo, não se deve aceitar esses princípios como livres do erro. É verdade que Descartes introduz a noção de movimento para explicar a dedução, porém esse movimento é puramente intelectual, e não fruto da imaginação.

No entanto, ainda que os primeiros princípios não possam estar fundados sobre a imaginação, esta pode ajudar o intelecto a compreendê-los. Na regra XII,

\footnotetext{
${ }^{65}$ Cf. CONIMBRICENSIS, De Anima, 1616, p. 27.

${ }^{66}$ Cf. CLAVIUS, 1603, p. 32.
} 
Descartes esclarece que as noções comuns são conhecidas pelo intelecto ou pelo intelecto considerando as imagens das coisas materiais. Assim, o intelecto acessa verdadeiramente os primeiros princípios, enquanto a imaginação o ajuda na compreensão. Dito de outro modo, Descartes aceita que a imaginação colabore com a intuição, mas não que ela mesma seja o fundamento dos primeiros princípios. Com efeito, o papel da imaginação é auxiliar (isto é, não necessário) e não suficiente para acessar os primeiros princípios.

\section{5}

\section{A dedução}

A intuição é o ato do intelecto humano capaz da apreensão da evidência, a qual, por sua vez, não é senão a verdade que nos aparece de maneira imediata. Contudo, nem todas as verdades são evidentes, há verdades que são obtidas a partir de proposições evidentes, isto é, que são derivadas ou que se seguem necessariamente. Essas verdades não são apreendidas pela dedução.

Tendo apresentado uma definição da intuição, Descartes introduz uma definição e uma explicação do que compreende por dedução. Eis a definição: "tudo aquilo que se conclui necessariamente doutras conhecidas com certeza". Quanto à explicação: "Mas foi preciso assim fazer, porque muitas coisas são conhecidas com certeza, embora elas mesmas não sejam evidentes, contato que deduzidas de princípios verdadeiros e conhecidos por um movimento contínuo e de nenhum modo interrompido. ${ }^{67}$

Uma vez que os primeiros princípios estão bem fundados na intuição, as deduções devem partir de princípios já estabelecidos e avançar até as conclusões que não são conhecidas com o mesmo grau de evidência. Primeiramente, essas conclusões, guardam a certeza fundada sobre os primeiros princípios, donde partem. Sob esse aspecto, as conclusões têm sua certeza derivada dos primeiros princípios da intuição. Assim, vê-se a importância de se bem fundas os princípios. Para ser mais preciso, é preciso dizer que as deduções partem de primeiros

${ }^{67}$ Definição: [...] per deductionem: per quam intelligimus, illud omne quod ex quibusdam alijs certo cognitis necessariò concluditur. Explicação: Sed hoc ita faciendum fuit, quia plurimae res certò sciuntur, quamvis non ipsae sint evidentes, modo tantùm à veris cognisque principijs deducantur per continuum \& nullibi interruptum cogitationis motum singula perspicuè intuentis [...]. Regras para a direção do espírito (AT, X, 369, 1. 20-26). 
princípios, proposições verdadeiras ou ainda proposições conhecidas através de uma dedução anterior.

Em segundo lugar, essas conclusões são certas graças à estrutura rigorosa da dedução. Por assim dizer, a certeza da operação dedutiva do intelecto repousa sobre uma necessidade lógica. Por essa razão a definição da dedução funda-se sobre a ideia de uma conclusão necessária (necessario concluditur). A intuição é evidente, enquanto a dedução é necessária. Esses dois atributos, a evidência da intuição e a necessidade da dedução, são por vezes contrastados por Descartes. A razão dessa oposição repousa sobre o fato de a evidência imediata não ter necessidade de ser exposta passo a passo numa cadeia dedutiva.

Por um lado, se encontramos a noção de simultaneidade na definição da intuição, de outro, não mais a encontramos na definição de dedução. $O$ ato dedutivo é descrito como um movimento intelectual, isto é, que parte de princípios verdadeiros e já conhecidos. Convém aqui observar que Descartes não diz que a dedução deve partir necessariamente de primeiros princípios, mas de princípios verdadeiros e conhecidos (vera cognitaque principia). Na realidade, esses devem ser compreendidos no sentido de premissas no contexto de uma dedução. Essa ambiguidade, contudo, já estava em Aristóteles: os princípios (ou archai) são compreendidos ora como premissas, ora como princípios (em sentido estrito como primeiros princípios). Assim, Descartes está consciente dessa diferença e, por isso, jamais disse que as deduções devem partir exclusivamente de primeiros princípios, mas de princípios verdadeiros e conhecidos. De fato, uma dedução pode ser feita a partir de proposições verdadeiras que foram obetidas de uma dedução anterior. Por esse motivo, Descartes acrescenta um outro atributo aos primeiros princípios, o de serem maximamente absolutos (maxime absoluti), denunciando o caráter primeiro desse princípios. ${ }^{68}$

Além do mais, o movimento assume um papel de suma importância. Ele é suficiente para distinguir a intuição da dedução, mas também para distinguir uma dedução de uma falácia. É preciso lembra o movimento dedutivo do pensamento não pode ser interrompido. Tal interrupção é suficiente para abortar a dedução. $\mathrm{Ou}$ seja, a dedução interrompida torna-se falaciosa quando suas cadeias não estão

\footnotetext{
${ }^{68}$ Regras para a direção do espírito (AT, X, 401, 1. 25).
} 
bem conectadas. Se por um lado a falta de atenção impede a intuição, por outro é a interrupção que impede a dedução.

Dessa maneira, nem tudo pode ser acessado pela intuição. É por isso que Descartes apela à dedução, que, concebida como um movimento ou certa sucessão, permite alcançar conclusões remotas (remotas conclusiones). A certeza é talvez a única característica partilhada por esses dois atos do intelecto. Trata-se, contudo, de duas formas da certeza. De um lado, a certeza imediata da intuição e, doutro, a certeza derivada da primeira. Noutras palavras, uma vez que garantimos a certeza imediata da intuição, as conclusões da dedução têm a sua certeza na soma dos passos da cadeia dedutiva. Isso prova que a dedução não deve ser compreendida como um ato incompatível coma intuição, mas como um ato complementar.

A dedução é, de fato, composta por um grupo de proposições que são apreendidas pela intuição, mas o encadeamento dessas proposições não pode ser acessado com o mesmo imediatismo da intuição. E uma vez que a dedução é composta por proposições intuitivas, a intuição é mais simples que a dedução. A simplicidade da intuição confere à intuição uma certeza superior àquela da dedução (certior est, quia simplicior). ${ }^{69}$ Apesar dessas diferenças, poder-se-ia dizer que uma intersecção entre esses dois atos do intelecto porque a dedução pressupõe a intuição. A dedução é capaz, por isso mesmo, de amplificar o espectro de conhecimento aberto pela intuição. Mas, em todo caso, a intuição preserva ainda uma forma de prioridade epistemológica e psicológica que se traduz numa primazia metodológica. Assim, a intuição é a ela mesma a condução e a fonte da certeza da dedução.

\section{6}

\section{Intuição e dedução}

É possível intuir não só primeiros princípios, mas o que Gilson chamou de “relações entre juízos". Segundo Descartes, conhecemos intuitivamente $2+2=3$ +1 a partir de outras duas proposições, $2+2=4$ e $3+1=4$. Dessa maneira, observamos ao menos uma dupla função da intuição. Ela não apreende somente os

\footnotetext{
${ }^{69}$ Regras para a direção do espírito (AT, X, 368, 1. 20-21).
} 
primeiros princípios do conhecimento mas também argumentos. Esse comentário levou alguns especialistas a se interrogarem sobre o limite entre a intuição e a dedução e a possibilidade de reduzir por completo o procedimento dedutivo do intelecto à uma dedução. Essa discussão dividiu os comentadores em duas posições, a saber: uma primeira segunda a qual se pode reduzir toda dedução, em última instância, a uma intuição e outra que dizia que se poderia reduzir somente alguns raciocínios dedutivos a uma intuição. ${ }^{70}$ Nas palavras de Sepper, o exemplo acima introduziu uma grande confusão, uma vez que se trata de uma inegável inferência. ${ }^{71}$

Qual é, contudo, a fronteira entre a intuição e a dedução? Descartes explica que algumas deduções podem ser apreendidas intuitivamente, a saber: as deduções cuja conclusão se segue imediatamente dos primeiros princípios. Por outro lado, há deduções que têm conclusões remotas, ou distantes. Estas últimas podem somente ser alcançadas pela dedução. O problema, contudo, permanece: o que Descartes compreende como "conclusões remotas"? Qual é o critério que permite distinguir uma conclusão imediata e uma que não o é?

Com efeito, a demarcação entre intuição e dedução repousa sobre uma consideração psicológica, uma vez que as proposições derivadas imediatamente dos primeiros princípios são conhecidas diversamente conforme nossa consideração "o conhecemos segundo os critérios "são conhecidos, sob uma consideração diferente, ora por intuição, ora por dedução" (sub diversa consideratione, modo per intuitum, modo per deductionem cognosci). ${ }^{72}$ Assim, podemos escolher entre o conhecimento intuitivo imediato e uma cadeia dedutiva, persistindo ainda o problema de como distingui o que é imediato e o que não o é.

Descartes admite a possibilidade de conceber intuitivamente os primeiros princípios como também algumas conclusões que se seguem imediatamente desses princípios (propositiones, quae ex primis principijs immediatè concluduntur). Assim, ele sustenta que os primeiros princípios bem como

\footnotetext{
${ }^{70}$ Vide, por exemplos, a posição de Gaukroger, que defende a redução estrita da dedução à intuição. Cf. GEUKROGER, 1989, p. 48-50.

${ }^{71}$ Cf. SEPPER, 1996, p. 131. Podemos levantar a hipótese, ao contrário do que diz Sepper, de que esse exemplo poderia talvez não se tratar de uma inferência, mas tão apenas da aplicação de um dos primeiros princípios, a noção-comum ilustrada na regra XII, que diz: "duas coisas iguais a uma terceira são iguais entre si”.

${ }^{72}$ Regras para a direção do espírito (AT, X, 370).
} 
conclusões imediatas podem ser apreendidos pela intuição e conclusões remotas, pela dedução. É preciso, contudo, observar que Descartes não estabelece claramente o que ele entende por conclusões imediatas e aquelas que não seriam. Segundo ele, há, contudo, um critério psicológico que é capaz de distingui-los: trata-se de uma consideração intelectual. Esse critério aparentemente subjetivo não é suficientemente claro e pode dar lugar a intepretações contraditórias acerca do limite entre a intuição e a dedução.

A regra XI apresenta alguns elementos que podem nos ajudar a compreender precisamente essa tensão. Afinal, a regra XI se propõe ela mesma a resolver os problemas suscitados pela regra III. Descartes explica que a dedução pode ser pensada (cogito) diferentemente segundo os diversos modos que nós consideramos o movimento, isto é: "a ser feita" (facienda) e "como já feita" (ut jam facta est). O que permite essa distinção é tão somente a atenção (attendemus) que dirigimos à dedução. No segundo caso, quando a dedução já feita, o movimento em jogo deve ser compreendido como aquele que torna possível inferir uma proposição de outra. Ele diz ainda que esse tipo de dedução não designa mais um movimento (nullum motum designat), pois este chegou ao fim (terminum motus). Dito isso, ele nos diz ainda que, sem nenhum movimento, a dedução pode ser dividida do seguinte modo: simples e perspícua (quando est simplex et perspicua) e múltipla et difícil (quando est multiplex et involuta). Assim, somente o primeiro tipo de dedução, a já feita, que seja ademais simples e transparente pode ser reduzida a uma intuição, ou, como diz o próprio Descartes, pode ser vista pela intuição (per intuitum videri). ${ }^{73}$

Apesar da explicação das Regras, são nas Meditações que encontramos uma série de exemplos em que se dá a intuição de inferências, e que são, além disso, de maior complexidade. Os comentários das Meditações pregam uma maior eficiência da intuição do que o exemplo trivial das Regras, $2+2=3+1$. Nas Meditações, Descartes menciona diversos exemplos envolvendo a intuição de deduções. Seus exemplos são, com efeito, teoremas euclidianos. O primeiro deles é a proposição euclidiana I.32, isto é, a de que a soma dos ângulos internos de um triângulo é igual a dois retos. Noutra passagem, cita a proposição euclidiana I.19,

\footnotetext{
${ }^{73}$ Regras para a direção do espírito (AT, X, 408-409).
} 
isto é, a de que o maior lado do triângulo é subtendido pelo maior ângulo, acrescentando inclusive que é possível conhecer clara e distintamente outras propriedades do triângulo, o que significa: outras tantas demonstrações. ${ }^{74}$

Ora, Descartes ilustra frequentemente a intuição com exemplos matemáticos. É de se esperar, portanto, que intuição desempenhe algum papel na sua geometria, e mais precisamente no texto que melhor incarna o seu projeto metodológico, A Geometria. Assim, selecionamos alguns trechos que podem de algum modo contribuir no esclarecimento da intuição em sua prática concreta. Trata-se de duas passagens n'A Geometria em que o vocabulário da intuição é emprego, isto é, Descartes não chega a usar o termo "intuição", mas fala de uma concepção clara e distinta.

\section{7}

\section{Intuição n'A Geometria}

A Geometria é o texto mais representativo da matemática cartesiana. É, além do mais, o que melhor expressa o método cartesiano, pensava seu próprio autor. Contudo, não pretendemos aqui chamar a atenção para os resultados matemáticos, mas para alguns detalhes metodológicos que Descartes apresenta, especialmente aqueles que dizem respeito à intuição. Desse modo, não analisaremos os resultados matemáticos em si, mas apenas focalizaremos a aparição do conceito de intuitção e de como modo esse mesmo conceito é articulado no contexto puramente prático de seu método. Quase sempre ignorada por aqueles que se proporam a abordar a intuição cartesiana, A Geometria parece revelar alguns elementos na compreensão desse conceito.

Ora, a intuição serve fundamentalmente à intuição de primeiros princípios. Seria de se esperar que a intuição fosse articulada conjuntamente aos princípios matemáticos n'A Geometria. Afinal, ele estabeleceu nas Regras que a intuição é por excelência aquele ato intelectual que apreende os primeiros princípios, inclusive os da matemática, como ele bem ilustra em diversos momentos. Assim, é legítimo nos perguntar o que aconteceu com os princípios da matemática n'A Geometria. Contudo, como já foi explicado no primeiro capítulo, Descartes

\footnotetext{
${ }^{74}$ Cf. Meditações Metafísicas (AT, VII, 64).
} 
contesta a utilidade metodológica dos princípios (vide seu comentário aos postulados e definições). Isso não significa que ele não aceitasse os princípios tradicionais da matemática, ele apenas não lhes confere um papel de destaque.

Ademais, Descartes não busca reformar os princípios (nem tão pouco as demonstrações) da geometria euclidiana. Longe de descreditar a geometria clássica, ele a toma como algo bem estabelecido. E, por essa razão, seu esforço resume-se numa tentativa de aperfeiçoá-la. As considerações sobre a natureza da intuição nas Regras garante os princípios matemáticos, as proposições triviais (como as do cálculo aritmético) e as demonstrações já conhecidas (sejam aquelas da geometria clássica ou as que foram obtidas e, pelo reitarado ato de repetição do movimento dedutivo, acabam alcançando a mesma evidência que a intuição). ${ }^{75}$

Quando nos debruçamos, de fato, sobre A Geometria, encontramos a intuição cartesiana servindo aos propósitos construtivos dos objetos geométricos. Por exemplo, logo no início do livro II, Descartes diz:

\begin{abstract}
Ora, enquanto abrimos assim o ângulo XYZ, o ponto B descreve a linha $\mathrm{AB}$, que é um círculo. $\mathrm{E}$ os outros pontos $\mathrm{D}, \mathrm{F}, \mathrm{H}$, onde se fazem as intersecções de outras regras, descrevem outras linhas curvas AD, $\mathrm{AF}, \mathrm{AH}$, cujas últimas são por ordem mais compostas que a primeira, e esta mais que o círculo; mas eu não vejo o que pode impedir que se conceba tão claramente e tão distintamente a descrição dessa primeira [curva $\mathrm{AD}$ ] como a do círculo, ou ao menos como a das seções cônicas; nem se pode impedir que se conceba a segunda, e a terceira, e todas as outras que se pode descrever, tanto como a primeira; nem consequentemente que se a aceite todas do mesmo modo para servir às especulações de geometria. (GRIFO NOSSO) ${ }^{76}$
\end{abstract}

Deste trecho: "que se conceba tão claramente (nettement) e tão distintamente a descrição dessa primeira como a do círculo ou, ao menos como a das seções

\footnotetext{
75 Tema desenvolvido na regra XI das Regras. Cf. Regras para a direção do espírito (AT, X, 408).

${ }^{76}$ Segue o comentário no original: "Or, pendant qu'on ouvre ainsi l'angle XYZ, le point B décrit la ligne $A B$, qui est un cercle; et les autres points $D, F, H$, où se font les intersections des autres règles, décrivent d'autres lignes courbes $A D, A F, A H$, dont les dernières sont par ordre plus composées que la première, et celle-ci plus que le cercle; mais je ne vois pas ce qui peut empêcher qu'on ne conçoive aussi nettement et aussi distinctement la description de cette première que du cercle, ou du moins que des sections coniques; ni ce qui peut empêcher qu'on ne conçoive la seconde, et la troisième, et toutes les autres qu'on peut décrire, aussi bien que la première; ni par conséquent qu'on ne les reçoive toutes en même façon pour servir aux spéculations de géométrie." A Geometria (AT, VI, 391-392).
} 
cônicas", extrai-se duas informações que não constam nos textos metodológicos de Descartes, ao menos não tão explicitamente. Em primeiro lugar, a possibilidade de se intuir as contruções diagramáticas. Com efeito, o objeto da intuição é, nessa passagem, o que Descartes chama de “descrição”. O vocabulário cartesiano n'A Geometria distingue descrição (description) e cálculo (calcul). Enquanto o primeiro se refere à figura diagramática, o segundo deve ser compreendido como o conjunto de operações realizadas a partir do simbolismo algébrico. Ambos são componentes das provas cartesianas, sobretudo na obra em questão, A Geometria.

Em segundo lugar, notamos que os objetos da geometria não são intuídos conforme diversos graus de clareza e distinção. Poderíamos pensar, como Bos, que as várias gradações de complexidade dos objetos geométricos corresponderiam ao grau de simplicidade ou complexidade da curva, classificada pelo gênero da equação algébrica ou movimento desempenhado na construção da curva. Bos pensa que há uma associação entre os atos intelectivos (intuição e dedução) e os objetos da geometria. Segundo a sua hipótese, o movimento envolvido na construção dos objetos mais complexos corresponderia ao movimento dedutivo, enquanto os objetos mais simples seriam acessados intuitivamente. ${ }^{77}$ Todavia, isso não se dá. A complexidade das curvas não corresponde a graus de clareza e distinção nem há qualquer tipo de relação entre os movimentos executados na construção do objeto matemático e a distinção entre intuição e dedução (que encontramos nas Regras). Desse modo, objetos mais simples, como retas e círculos, são intuídos com igual clareza e distinção que as curvas mais complexas, como as seções cônicas, e assim sucessivamente. As figuras que não são geométricas (ou simplesmente mecânicas) não são apreendidas segundo o critério de inteligibilidade, não sendo assim apreendidas pela intuição nem pela dedução.

\footnotetext{
${ }^{77}$ Traduzo aqui a hipótese de Bos: "Por que Descartes escolheu o critério dos movimentos para a aceitabilidade? A nossos olhos de modernos, isso não parece muito claro nem muito convincente. Mas, se nós nos lembramos dos pontos de vista de Descartes sobre a certeza matemática tal como ele as exprime nas Regras (por volta de 1628), nós podemos compreender sua escolha: ele teria defendido que o espírito tem uma intuição clara e distinta desse tipo de movimento, e que as combinações de movimentos são um caso onde a dedução, no sentido de uma sequencia ordenada de intuições sucessivas, pode conservar a certeza dos primeiros movimentos ao longo de toda a sequência de movimentos encadeados até o final. De fato, se nós procurarmos n'A Geometria as "longas cadeias de razões" mencionadas no Discurso, nós não as encontraremos na dedução lógica do axioma ao teorema, mas nas cadeias de movimentos que combinam o traçado das curvas aceitáveis nas construções geométricas.” Cf. BOS, 1998, p. 309.
} 
Contudo, podemos ainda fazer algumas considerações gerais sobre a aparição da intuição n'A Geometria a partir desse trecho. Vê-se que o diagrama, ou descrição, não é intuído como parte de uma demonstração. O diagrama não fornece no caso analisado nenhum elemento para a prova. Na realidade, a intuição do diagrama em questão está associada a outro papel. Com efeito, a intuição dos objetos geométricos relaciona-se com uma dimensão fundacional. O livro II d'A Geometria começa propondo uma demarcação entre os objetos geométricos e objetos que não são geométricos, os mecânicos simplesmente. A intuição recai, portanto, sobre os objetos legitimamente geométricos. Por isso mesmo ele enfatiza no final da citação as seções cônicas e outras curvas mais complexas são concebidas com a mesma clareza e distinção como o círculo. Em síntese, a intuição surge para legitimar o emprego das seções cônicas e curvas mais complexas, que estavam até então fora do cânon geométrico.

Noutra passagem encontramos um apelo à construção geométrica, uma vez que o diagrama forneceria o conhecimento mais distinto da raiz de uma determinada equação cúbica.

Pois, se, por exemplo, se se pensa conhecer a raiz dessa Equação, $z^{3}=-q z+p$, porque se sabe que ela é composta de duas linhas, em que uma é o lado de um cubo, do qual o conteúdo [volume] é $\frac{1}{2} q$, ajustado ao lado de um quadrado cujo conteúdo [volume] é est $\frac{1}{4} q q-$ $\frac{1}{27} p^{3}$; E o outro é o lado de um outro cubo, cujo conteúdo é a diferença; que há entre $\frac{1}{2} q$, e o lado do quadrado $\frac{1}{4} q q-\frac{1}{27} p^{3}$, que é tudo que se aprende pela regra de Cardano. Não há dúvidas que $s e$ conhece tanto ou mais distintamente a raiz deste, $z^{3}=q-p$, se se o considera inscrito em um círculo cujo semidiâmetro é $\sqrt{\frac{1}{3} p}$, e sabendo que ela é subtendida de um arco cujo triplo tem por subtendido $\frac{3 q}{p}$. Mesmos esses termos são muito menos confusos que os outros, e eles se encontram mais curtos, se se quer usar algum símbolo particular para exprimir esses subentendidos, de tal modo que se faz do símbolo $\sqrt{C}$. para exprimir o lado dos cubos. E assim, pode-se, depois disso, exprimir as raízes de todas as Equações que vão até o quadrado do quadrado pelas regras acima explicadas. De modo que eu não saiba desejar acerca dessa matéria. Pois enfim a natureza das raízes não permite que elas sejam expressas em termos mais simples, nem que sejam determinadas por nenhuma construção que sejam ao mesmo tempo mais geral e mais fácil. (GRIFO NOSSO) ${ }^{78}$

\footnotetext{
${ }^{78}$ No original : Car si par exemple, on pense connoistre la racine de cete Equation, $z^{3}=-q z+$ $p$, a cause qu'on sçait qu'elle est composée de deux lignes, dont une est costé d'un cube, duquel le contenu est $\frac{1}{2} q$, adiousté au costé d'un quarré, duquel derechef le contenu est $\frac{1}{4} q q-\frac{1}{27} p^{3} ; E t$
} 
O trecho mais importante é este: "Não há dúvida de que se conhece tanto ou mais distintamente a raiz disso aqui, $z^{3}=q-p$, considerando-a inscrita num círculo [...]" ${ }^{79}$ Assim, segundo esse comentário, parece haver uma primazia do diagrama em relação às equações algébricas. A construção diagramática parece fornecer aqui um conhecimento mais distinto que o da fórmula algébrica.

A segunda citação retirada d'A Geometria parece revelar outra função cumprida pela intuição além da fundacional, analisada na primeira citação. Tratase, com efeito, de uma função heurística. Pois, a intuição do diagrama pode auxiliar na compreensão ou na facilitação do entendimento da prova. Sendo assim, a intuição não é capaz de apresentar nenhum elemento novo à demonstração. Isto é, a intuição não é usada para inserir uma informação ou passo na prova, seja através de princípios (como axiomas e definições), seja com teoremas da geometria clássica. Ela simplesmente reforça uma informação já contida na prova. Poder-se-ia, ainda, cogitar a possibilidade de a intuição responder às dificuldades suscitadas a partir das informações diagramáticas. Um exemplo de informação diagramática é aquele da proposição euclidiana I.1, analisada no primeiro capítulo, em que a informação do ponto $\mathrm{C}$, resultado da intersecção de dois círculos, é obtida através da visualização do diagrama. Será que informações como esta, que eram compreendidas por alguns como uma falha

l'autre est le costé d'un autre cube, dont le contenu est la difference; qui est entre $\frac{1}{2} q$, \& le costé de ce carré $\frac{1}{4} q q-\frac{1}{27} p^{3}$, qui est tout ce qu'on en apprent par la reigle de Cardan. Il ny a point de doute qu'on ne connoisse autant ou plus distinctement la racine de celle cy, $z^{3}=q-p$, en la considerant inscrite dans un cercle dont le demi-diamètre est $\sqrt{\frac{1}{3} p}$, et sachant qu'elle y est la subtendue d'un arc dont le triple a pour sa subtendue $\frac{3 q}{p}$ Mesme ces termes sont beaucoup moins embarrassés que les autres, et ils se trouveront beaucoup plus courts, si on veut user de quelque chiffre particulier pour exprimer ces subtendues, ainsi qu'on fait du chiffre $\sqrt{C}$. pour exprimer le costé des cubes. Et on peut aussi, en suíte de cecy, exprimer les racines de toutes les Equations qui montent jusques au quarré, par les reigles cy dessus expliquées. En sorte que ie ne sçache rien de plus a desirer en cete matiere. Car enfin la nature de ces racines ne permet pas qu'on les exprime en termes plus simples, ny qu'on les determine par aucune construction qui soit ensemble plus generale \& plus facile. A Geometria (AT, VI, 474-475).

79 A simples menção a um conhecimento distinto não significa que se trate de uma intuição. Contudo, nas Regras, Descartes desenvolve a tese de que a instanciação de uma figura geométrica pode colaborar com a percepção intuitiva. Ou seja, a imaginação pode auxiliar a intuição com a apresentação de um exemplo figurado na imaginação. Ademais, nas Regras, quando isso ocorre, a representação em jogo é guardada pelo nosso pensamento atento mais facilmente (facilius nostra cogitatio retineatur attenta). Cf. Regras para a direção do espírito (AT, X, 453). Consequentemente, aumenta-se a distinção da concepção clara e distinta. Ora, Descartes havia já reconhecido o papel do diagrama, representado na imaginação, como um elemento heurístico e que, além do mais, provoca o aumento da distinção. Sendo assim, é provável também que a noção de intuição esteja por detrás da menção a um conhecimento distinto n'A Geometria. 
no rigor da prova (também discutidos no primeiro capítulo), poderiam ser simplesmente intuídas? Ao menos n'A Geometria não há nenhuma resposta explícita. De fato, não encontramos nenhum papel da intuição relacionado à apreensão de informações diagramáticas.

Por fim, concluímos que a análise da articulação da intuição cartesiana no livro d'A Geometria pode nos levar a algumas funções não contempladas nos textos metodológicos, ou ao menos não de modo explícito. Primeiramente, a intuição parece associada a uma função fundacional, que é capaz de reconhecer os objetos legitimamente geométricos. No outro caso, a intuição serve como uma espécie de elemento heurístico, colaborando na apreensão do resultado da prova. Em nenhum dos casos, a intuição serviu à visualização de aspectos diagramáticos da prova. Além do mais, algumas das funções atribuídas à intuição nas Regras não podem ser confirmadas, ao menos de modo explícito n'A Geometria. Os exemplos que estão relacionados com a intuição nas Regras envolvem princípios matemáticos (como definições e noções-comuns geométricas), proposições triviais da aritmética e demonstrações da geometria clássica, que podem ser reduzidas a uma intuição por um esforço de repetição do movimento dedutivo do intelecto. Contudo, os objetos postos em questão n'A Geometria são os objetos da geometria 


\section{Duas médias proporcionais: Descartes entre Roberval e Mydorge ${ }^{80}$}

\section{1}

\section{Introdução}

O problema das duas médias proporcionais pode ser reescrito modernamente do seguinte modo: dado dois segmentos de reta $a$ e $b$, encontrar as duas médias proporcionais (isto é: dois segmentos de reta) $x$ e $y$, tais que $\frac{a}{x}=\frac{x}{y}=$ $\frac{y}{b}$. Embora o problema das duas médias proporcionais tenha sua origem na matemática clássica, Bos o destaca como o problema mais preeminente, no século XVI, dentre aqueles problemas clássicos que não podem ser resolvidos por régua e compasso (ou retas e círculos). ${ }^{81}$

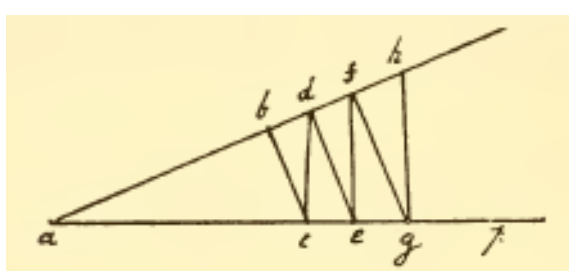

Figura 2 Mesolabium (AT, X, 234)

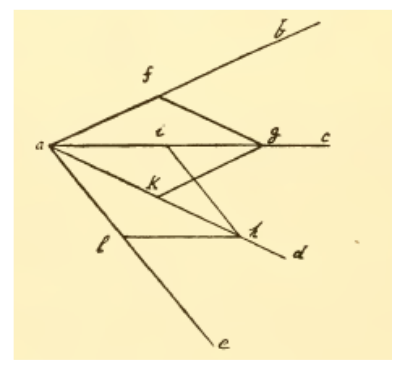

Figura 3 Trisector (AT, X, 240)

Descartes, ao longo de sua carreira matemática, tentou resolvê-lo com métodos diferentes. Nas Cogitationes Privatae (1619), Descartes propunha a resolução e generalização de problemas de geometria a partir da construção de compassos teóricos, por exemplo: o mesolabium (que servia na resolução de um problema com quaisquer médias proporcionais, figura 1) e o trisector (que resolvia o problema da trissecção do ângulo e poderia ser adaptado para servir à resolução de outras secções angulares, figura 5). Em sua mocidade, chegou a pensar que o problema das duas médias proporcionais seria resolvido como um

\footnotetext{
${ }^{80}$ As demonstrações discutidas aqui se encontram traduzidas no final desse trabalho, em anexo.

${ }^{81}$ Cf. BOS, 2001, p. 27.
} 
caso particular do mesolabium. Esses compassos, no entanto, perderam importância e deram lugar a um crescente papel da álgebra na obra matemática de Descartes. Já em 1637, no livro III d'A Geometria, a adoção de métodos algébricos para a resolução de problemas geométricos resultará na construção geral de raízes do terceiro e quarto graus, agora por meio de parábola e círculo.

Todavia, antes da publicação d'A Geometria, Descarte estava empenhado na busca de uma solução para o problema das duas médias proporcionais, especialmente na década de 1620. Ainda pouco estudado, o desenvolvimento desse mesmo problema antes da publicação d'A Geometria. Nos últimos tempos, o problema das duas médias proporcionais tem ganhado a atenção de alguns especialistas, como Bos, Serfati, Rabouin, Lützen e Crippa. Contudo, uma parte dos especialistas, como Lützen e Crippa, focalizou sua abordagem essencialmente no argumento desenvolvido por Descartes n'A Geometria de que o problema de duas médias proporcionais bem como outros problemas envolvendo a construção de equações do terceiro e quarto graus eram impossíveis de serem construídos com retas e círculos, antecipando uma prova que só seria realmente apresentada no século XIX, pelas mãos do matemático Pierre Wantzel. ${ }^{82}$

Há, não obstante, lacunas no desenvolvimento histórico desse problema antes de sua publicação n'A Geometria, mais precisamente o período que cobre os meados da década de 1620 e início da década de 1630. Nessa época, Descartes e outros matemáticos de seu círculo encontravam-se empenhados na busca construção para as duas médias proporcionais. E, por isso mesmo, a reconstrução histórica desse problema nos permite comparar os resultados apresentados por Descartes e outros matemáticos, que não compartilhavam da mesma concepção de metodológica no âmbito das matemáticas.

\section{2}

\section{"Novos Arquimedes"}

Em La vérité des sciences contre les septiques ou Pyrrhoniens (1625), Costabel encontra um comentário de Mersenne que pode explicar a motivação de Descartes em buscar uma solução para o problema das duas médias proporcionais.

\footnotetext{
${ }^{82}$ Cf. LÜTZEN, 2010, p. 12-18 e CRIPPA, 2014, p. 207-208.
} 
${ }^{83} \mathrm{O}$ comentador também estima que, provavelmente, Descartes teria elaborado sua solução no outono de 1628, uma vez que a visita feita a Beeckman, em 8 de outubro de 1628, coincidiria com as suas estadias na França. Posteriormente, o fruto desse encontro apareceria mais tarde, cerca de 3 meses depois, em 1629, publicado no Journal, de Beeckman.

Costabel ${ }^{84}$ nos lembra também que Mersenne, em La vérité des sciences, faz uma apelo aos "novos Arquimedes", a fim de que estes façam calar não só aqueles que se utilizam de paralogismos para demonstrar a quadratura do círculo, a duplicação do cubo e a trisecção do ângulo, isto é: os problemas especiais da geometria grega, que não podem ser resolvidos por meio de régua e compasso, mas também aqueles que pensam ter encontrado erros nas definições e proposições euclidianas.

\begin{abstract}
Queira Deus nos fazer nesse século alguns novos Arquimedes, que conduzam as Matemáticas até a sua última perfeição, \& que imponham um silêncio eterno à quantidade de ignorantes que querem persuadir através de seus sofismas, \& paralogismos, que eles encontraram a quadradura do círculo, a duplicação do cubo, a trisecção do ângulo, \& reconheceram diversos erros nas definições, \& proposições de Euclides, ainda que a maior parte destes temerários não saibam sequer os primeiros termos da Geometria, nem a maneira de se falar sobre isso. É por isso que eu sei de muito bom grado que os excelentes Geômetras não querem conferir [falar] com eles, nem mesmo os escutar, por medo que por tal condescendência se crêsse que eles aprovam a ignorância destes temerários. ${ }^{85}$
\end{abstract}

É controversa a opinião dos comentadores sobre o que teria levado Descartes a insistir numa resolução do problema das duas médias proporcionais a partir de uma seção cônica, similarmente às demonstrações de Menêcmo (que

\footnotetext{
${ }^{83}$ Cf. COSTABEL, 1982, p. 51.

${ }^{84}$ Cf. COSTABEL, 1982, p. 51.

${ }^{85}$ No texto em francês, lê-se o seguinte: Plaise à Dieu de nous faire remaistre en ce siecle quelques nouveux Archimedes, qui conduisent les Mathematiques jusques à leur dernierer perfection, \& qui imposent un silence éternel à quantité d'ignorans qui veulent persuader par leurs sophismes, \& paralogismes, qu'ils ont trouvé la quadrature du cercle, la duplication du cube, la trisection de l'angle, \& reconu plusieurs erreurs dans les definitions, \& propositions d'Euclide, bien que la pluspart de ces temeraires de scachent pas seulement les primiers termes de la Geometrie, ni la maniere d'en parler. C'est pourquoy ie scay fort bon gré aux excellents Geometres de ne vouloir pas conferer avec eux, ni mesme les écouter, de peur que par ceste condescendence on croye qu'ils approuvent l'ignorance de ces temeraires. Cf. MERSENNE, 1625 , p. 750 .
} 
envolviam ora duas parábolas, ora uma parábola e uma hipérbole), uma vez que, como observa Milhaud, os comentadores que tinha na época à sua disposição pouco enfatizavam a demonstração de Menêcmo. O comentário de Pappus traduzido por Commandino, por exemplo, salienta a resolução pela concóide de Nicomedes e os instrumentos, como o de Eratóstenes, mais do que a aplicação de seções cônicas. No comentário de Clavius a essas demonstrações, que imita o de Pappus, nota-se também uma clara predileção pelas curvas especiais do que pelas seções cônicas. Clavius aliás menciona os resultados de Menêcmo sem analisálos. Talvez, como pensou Milhaud, tenha lhe surgido o desejo de explorar um caminho de construção que julgou pouco trilhado. Isso explicaria a atenção que Descartes deu ao papel das seções cônicas. Milhaud sugere ainda a possibilidade de Descartes ter acessado, no tempo do séjour em Breda, a edição das obras completas de Arquimedes, que surgiu na Basiléia, em 1543, traduzida por Jacob de Cremona e que continha o Comentário de Eutócio, onde justamente se encontra a demonstração de Menêcmo. Contudo, é, no nosso entender, muito provável também que Descartes tenha acessado a tradução parisiense de David Rivault, datada de 1615 e que também guardava a demonstração de Menêcmo. Em La vérité des sciences, Mersenne faz uma clara menção à edição de Rivault, na qual se encontra um comentário da demonstração de Menêcmo. Ei-la, pois:

\section{[...] Rivault mostra a maneira de encontrar as duas médias proporcionais da qual Menêcmo se serviu, a saber: pela parábola, que se pode também encontrar através doutras seções cônicas. ${ }^{86}$}

Shea, por outro lado, pensa que Descartes ter-se-ia interessado na resolução das duas médias proporcionais em virtude de seus estudos em teoria musical. O especialista pensa comprová-lo através do primeiro trabalho publicado de Descartes, Compendium musicae (1619) e com sua preocupação em demonstrá-la nas Cogitationes através de um compasso teórico (vide figura 1), inspirado na demonstração de Eratóstenes, que ele tomara conhecimento, possivelmente, segundo o mesmo comentador, a partir do trabalho de Gioseffo Zarlino. Shea enfatiza ainda que dominava o italiano. Porém, é também que possível que tivesse acessado a obra do teórico musical por meio da tradução de

\footnotetext{
${ }^{86}$ No original: "[...]Rivault montre la maniere de treuver les deux moyennes proportionelles de laquelle Menechmus se servoit, sçavoir est par la parabole, ce qu'on peut aussi treuver par les autres sections coniques." Cf. MERSENNE, 1637, p. 861.
} 
seu amigo Claude Hardy. Por fim, ambas as teses, a de Milhaud e Shea, não são conflitantes e poderiam ser ambas possíveis.

No verão de 1625, Descartes mostrou uma construção (sem demonstração) de duas médias proporcionais a Mersenne, o qual a publicará mais tarde no Harmonicorum instrumentorum libri IV (1636) e na segunda parte da Harmonie universelle (1637). Curiosamente, as duas obras de Mersenne aqui citadas são sobre teoria musical, servindo a demonstração na determinação de tons e semitons. Na versão em latim, encontra-se uma instrução de construção para os fabricantes de sinos; já na versão francesa, encontramos uma instrução para os fabricantes de órgão. A construção fora divulgada por Mersenne a outros matemáticos. Um deles, Roberval, fornece uma demonstração - que Descartes tomará notícia em 1632 e que será publicada conjuntamente com a construção de Descartes nos livros de Mersenne supracitados. Contudo, ainda no ano de 1625, Descartes recebe uma demonstração elaborada ao que tudo indica por Mydorge (podendo ter havido a colaboração de Descartes), que é referido por Beeckman como um "certo matemático francês de Paris" (mathematicus quidam Gallus Parisijs). ${ }^{87}$ A demonstração de Mydorge, curiosamente, segue um estilo organizado e divide-se em três etapas: analiticamente ('Av $\alpha \lambda \imath \tau \imath \kappa \tilde{\omega} \varsigma$ ),

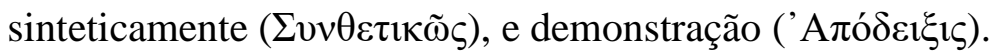

Em 1628, numa visita a Beeckman, Descartes mostra-lhe não somente a demonstração de Mydorge, mas também uma construção de sua própria autoria para raízes de equações do terceiro e quarto graus $\left(z^{4}= \pm a z^{2} \pm b z \pm c\right)$ - a qual é feita também a partir da intersecção de uma parábola e de um círculo e que torna o problema das duas médias proporcionais um caso particular da construção dessas equações. Tanto a demonstração de Mydorge como a de Descartes serão publicadas no jornal de Beeckman, a pedido de Descartes, em 1629. Ademais a primeira será repetida no terceiro livro d'A Geometria (1637) com algumas alterações e reescrita algebricamente $\left(z^{3}=a^{2} q\right)$, onde $a$ e $q$ são duas linhas entre as quais se pretende inserir duas médias proporcionais), mas sem nenhuma

\footnotetext{
${ }^{87}$ Cf. Descartes e Beeckman (AT, X, 342).
} 
referência a Mydorge e margeado pelo seguinte subtítulo: "A descoberta de duas médias proporcionais". ${ }^{88}$

Ao compararmos as duas demonstrações de duas médias proporcionais, a de Roberval e a que Mydorge (elaborada conjuntamente com Descartes), notamos uma diferença marcante no estilo de demonstração das duas provas. Essa diferença, como é bem observada por Shea ${ }^{89}$, consiste no fato de Roberval seguir um estilo euclidiano, aplicando explicitamente e repetidas vezes a proposição II.7 e, poder-se-ia acrescentar, os axiomas I.2 e I.3 d'Os Elementos, além de adotar uma linguagem essencialista (e.g.: “conforme a natureza da parábola”). Por outro lado, Mydorge não o faz dessa maneira, nem muito menos Descartes em seu método de construção de equações de terceiro e quarto graus. Não há nestes últimos, portanto, nenhuma referência explícita a teoremas euclidianos, e não o fazem em uma linguagem essencialista, que é substituída, no caso da demonstração de Descartes, por uma linguagem construtiva de comando. Mydorge em sua demonstração evoca a utilização de triângulos semelhantes (triangula similia), que depende implicitamente da demonstração VI.5, de Euclides, e que, como também observa Shea, era o método preferido de Descartes, confessado por ele em uma carta de seu punho a Elisabeth:

\footnotetext{
Eu sempre observo, ao investigar uma questão de Geometria, que as linhas, as quais eu me sirvo para a encontrar, sejam paralelas, ou se entrecortem em ângulos retos, tanto quanto possível; e eu não considero outros Teoremas, senão que os lados dos triângulos semelhantes tenham proporção semelhante entre si, e que, nos triângulos retângulos, o quadrado da base seja igual aos dois quadrados dos lados.
}

E eu não temo supor muitas quantidades incógnitas, a fim de reduzir a questão a tais termos, dependendo senão desses dois Teoremas; ao contrário, eu prefiro supô-las em maior que menor quantidade. Pois, por esse meio, eu vejo mais claramente tudo que eu faço, \&, ao resolvê-las, eu melhor encontro os caminhos curtos; \& me isento de multiplicações supérfluas; ao invés de prolongar outras linhas, \& de se servir de outros Teoremas, ainda que se possa chegar por sorte a um caminho mais curto que o meu, contudo, dá-se quase sempre o contrário. E não se vê tão bem o que se faz, a não ser que se tenha a demonstração do Teorema em jogo bem presente ao espírito; \& nesse caso, quase sempre, depende-se da consideração de alguns triângulos,

${ }^{88}$ L'invention de deux moyenes proportionelles.

${ }^{89}$ Cf. SHEA, 1993, p. 86. 
que são ou retângulos, ou semelhantes entre si, \& assim se regressa no caminho que eu proponho. (GRIFO NOSSO) ${ }^{90}$

As observações de Shea são notórias, mas cremos não serem suficientes para entender o porquê de Descartes ter ignorado a demonstração de Roberval e aprovado a demonstração de Mydorge, servindo-se dela inclusive n'A Geometria. Não nos parece correto que Descartes desprezasse a demonstração de Roberval por estar em "estilo euclidano" (no sentido de que se refere explicitamente a princípios e teoremas euclidanos), uma vez que o próprio, embora não se sirva do método axiomático, não mantém nenhuma restrição severa à aplicação de teoremas euclidianos, chegando ele mesmo a utilizá-los implicitamente em diversas passagens d'A Geometria, especialmente os do livro VI d'Os Elementos.

\section{3}

\section{O problema das duas médias proporcionais na correspondência}

Antes de comentar brevemente as duas demonstrações, é importante narrar a reação de Descartes diante das duas demonstrações, a de Mydorge e de Roberval. A troca se dá em sua correspondência com Mersenne. Numa carta de 4 de novembro de 1630, Descartes comunica a Mersenne o seguinte:

[...] Pois se se quer demonstrar pelos sólidos, a coisa é possível, como vós sabeis que eu mostrei outrora a construção ao Sr. Hardy e ao Sr. Mydorge, a qual o Sr. Mydorge demonstrou muito bem; mas se se pensa encontrar doutra maneira, é certo que se erra. (GRIFO NOSSO) 91

\footnotetext{
${ }^{90}$ Segue a versão original: I'observe tousjours, en cherchant une question de Geometrie, que les lignes, dont ie me sers pour la trouver, soient paralleles, ou s'entrecouppent à angles droits, le plus qu'il est possible; \& ie ne considere point d'autres Theoremes, sinon que les costez des triangles semblables ont semblable proportion entr'eux, \& que, dans les triangles rectangles, le quarré de la base est égal aux deux quarrez des costez. Carta de Descartes a Elisabeth de novembro de 1643 (AT, IV, 38).

91 Segue a versão original: Je ne me sçavrois imaginer qu'em ce que vous me mandez de la duplication du cube, il puisse y avoir de quoy s'arrester une demie heure. Car si on la veut demonstrer par les solides, la chose est possible, comme vous sçavez que j'em ay autresfois fait voir la construction à M. Hardy \& à M. Mydorge, laquelle M. Mydorge a fort bien demonstrée; mais si on la pense trouver autrement, il est certain qu'on se méprend. Et ie ne crains point de supposer plusieurs quantitez inconnuës, pour reduire la question à tels termes, qu'elle ne depende que de ces deux Theoremes; au contraire, i'aime mieux en supposer plus que moins. Car, par ce moyen, ie voy plus clairement tout ce que ie fais, \& en les demeslant ie trouve mieux les plus courts chemins; \& m'exempte de multiplications superfluës; au lieu que, si l'on tire d'autres lignes, \& qu'on se serve d'autres Theoremes, bien qu'il puisse arriver, par hazard, que le chemin qu'on trouvera soit plus court que le mien, toutesfois il arrive quasi toujours le contraire. Et on ne voit point si bien ce qu'on fait, si ce n'est qu'on ait la demonstration du Theoreme dont on se sert fort presente en l'esprit; \& en ce cas on trouve, quasi toujours, qu'il depend de la consideration
} 
Nessa passagem Descartes não só se refere de modo elogioso à demonstração de Mydorge (acentuado pelo grifo acima) como também estabelece a unicidade da prova, uma vez que é, em seu entender, a única maneira possível de provar a inserção de duas médias proporcionais.

Nota-se nessa carta, bem como numa de 10 de maio de 1632, uma referência ao polímata Claude Hardy, o qual, embora estivesse envolvido no desafio elaborado por Descartes de demonstrar a duplicação do cubo a partir de uma parábola e de um círculo em 1625, não foi bem sucedido em sua tentativa. Contudo, tão logo houvera passado o desafio, em 1630, Hardy publicou um livro (Examen de la duplication du cube, et quadrature du cercle. [...]), objetando algumas demonstrações (incluindo uma de duplicação do cubo) dadas por Paul Yvon ${ }^{92}$, que, por sua vez, houvera, já em 1619, apresentado uma pseudodemonstração da duplicação do cubo no seguinte livro: Quadrature $d u$ cercle, ou Moyen de trouver un quarré égal au cercle donné et au contraire un cercle égal au quarré proposé [...]. Após a publicação de seu livro, em 1628, Yvon chegou a anunciar a demonstração através de cartazes nas ruas, e submeteuse ele mesmo à avaliação de homens versados na matemática, como Mydorge e o próprio Hardy. Apesar do alarde e de o mesmo ter alcançado a simpatia do rei Luís XIII bem como alguns professores da época, Mydorge, na ocasião, apontoulhe o erro.

Na carta de maio de 1632, Descartes cita novamente seus amigos de Paris, Mydorge e Hardy. Vejamo-la:

A mim estava fácil ver a duplicação do cubo dos Senhores M(ydorge) e $\mathrm{H}(\operatorname{ardy})$ com os livros que vós me enviastes, e parece-me que vós me mandastes aquela que seria; mas eu não a encontrei. ${ }^{93}$

de quelques triangles, qui sont ou rectangles, ou semblables entr'aux, \& ainsi on retombe dans le chemin que ie tiens. Carta de Descartes a Mersenne de 4 de novembro de 1630 (AT, I, 175, 1. 511).

92 Paul Yvon, Sieur de la Leu, (15?-1646), nascido em Touraine, foi um matemático que fez fortuna com o trabalho de comerciante armador. Ademais, em 1592 comprou a senhoria de Laleu, tendo construído um castelo por lá. Foi também vereador em La Rochelle e depois prefeito na mesma cidade. Em 1633, decide viver em Paris, onde se converte ao protestantismo.

${ }^{93}$ No original: I'eusse esté bien aise de voir la duplication du cube de Messieurs M(ydorge) \& H(ardy) avec les livres que vous m'avez envoyez, \& il me semble que vous m'aviez mandé qu'elle y seroit; mais je ne l'y ay point trouvée. Carta de Descartes a Mersenne de 10 de maio de 1632 (AT, I, 252). 
Noutra carta de junho de 1632, em contraste, ao receber a demonstração de Roberval, Descartes, como constata Shea ${ }^{94}$, aparenta indiferença e salienta o fato de a demonstração nunca lhe ter parecido difícil. Vejamos:

Eu não vos agradeci na minha última [carta] pela demonstração das duas médias proporcionais que vós tínheis me enviado; mas eu ainda não havia recebido vossa carta e eu vos direi que o Sr. Mydorge encontrou também a demonstração, desde quando vós me solicitou a construção, e que eu nunca a julguei ser difícil. Eu teria preferido que vós tivésseis proposto a construção de modo a dividir o ângulo em três, a qual, se eu não me engano, eu vos dei ao mesmo tempo que a outra; pois ela é um pouco menos fácil, e o Sr. Mydorge me confessou que não pôde demonstrar. (GRIFO NOSSO) ${ }^{95}$

\section{4}

\section{O relato de Mersenne}

Há ainda os comentários tecidos por Mersenne, que devem ser levados em consideração, a fim de se extrair maiores detalhes do contexto. Em nenhuma passagem dos livros de Mersenne o nome de Descartes é mencionado, não lhe atribuindo, explicitamente, a construção que é publicada. Todavia, não poupa elogios ao autor da construção tanto na versão latina, ao chamá-lo de "grande homem" (vir summus), como na versão francesa, onde é "um homem de condição e de mérito, que por seu raro espírito é um dos maiores ornamentos da nossa França" (un homme de condition \& de merite, qui pour son rare esprit est l'un des plus grand ornemens de nostre France).

Descartes propõe a resolução do problema da duplicação do cubo a partir da intersecção de uma parábola e de um círculo, o que é meramente observado na versão latina "duas médias proporcionais encontradas com a ajuda de uma parábola" (duas medias proportionales unius ope Parabolae invenit), na versão francesa é acompanhado de uma longa explicação e um histórico do problema,

\footnotetext{
${ }^{94}$ Cf. SHEA, 1993, p. 86.

${ }^{95}$ Segue a versão original: Je ne vous avois point remercié, em ma derniere, de la demonstration des deux moyennes proportionelles que vous m'avez envoyée; mais je n'avois pas encore receu vos lettres, \& je vous diray que M. Mydorge em trouva aussi la demonstration, dés lors que vous m'em fistes faire la construction, \& que je ne l'ay jamais jugée estre difficile. J'aimerois mieux que vous eussiez proposé la constuctions de la façon de diviser l'angle em trois, laquelle, si je ne me trompe, je vous donné em mesme temps que l'autre; car elle est un peu moins aisée, \& $M$. Mydorge me confessa qu'il ne l'avoit peu demonstrer. Carta de Descartes a Mersenne de julho de 1632 (AT, I, 256, 1. 4-15).
} 
citando matemáticos que forneceram demonstrações ora por "lugares sólidos" (como Menêcmo), ora por "lugares lineares" (como Nicomedes, Díocles e o contemporâneo Viète), ou ainda por "movimentos envolvidos" (como Platão, Arquitas, Fílon de Bizâncio, Pappus e Sporus) e, finalmente, "por descrições de círculos à sorte" (como Heron e Apolônio). ${ }^{96}$

É na versão francesa também que se encontra a consideração de Mersenne de que essa construção (isto é, a construção proposta por Descartes) é a mais simples de todas, pois envolve apenas uma parábola e um círculo. Em um primeiro momento: "Essa construção é, a meu ver, a mais simples de todas aquelas que foram encontradas até agora para a solução desse problema, do qual depende a tão célebre duplicação do cubo, e que foi tão investigada pelos geômetras antigos e modernos [...]". ${ }^{97}$ Ei-la, reiterada depois da consideração acerca do desenvolvimento histórico do problema: "Mas eu estimo ainda mais aquela que segue, a qual se faz por meio somente de uma parábola, de um círculo e de uma linha reta [...]", que fora pensada por Descartes. ${ }^{98}$

Feita essa consideração, é importante notar que o comentário, tecido por Shea, de que Mersenne teria preferido a construção de Roberval por ser a mais fácil é absolutamente falso. ${ }^{99}$ Shea considera a construção na versão latina, que é de Descartes, como diferente da versão francesa, que ele pensou ser de Roberval, mas que é uma variação do mesmo diagrama da versão latina, adaptado à demonstração de Roberval. Contudo, a construção da intersecção de uma parábola e de um círculo, que é a construção a que se refere Mersenne elogiosamente, foi pensada por Descartes, o qual espera a demonstração, como se vê logo abaixo: "cuja demonstração e muito mais esperaremos do seu inventor" (cuius demonstrationem ab illius inventore cum aliis pluribus expectabimus). ${ }^{100} \mathrm{Em}$ resumo, Descartes lhe dá a construção, mas a demonstração, elaborada a partir do

\footnotetext{
${ }^{96}$ Embora Mersenne não tivesse notícia, Crippa mostra que já havia uma solução efetiva para a construção de duas médias proporcionais de uma matemático andaluz do século $\mathrm{X}$, antes mesmo das do século XVII. Cf. CRIPPA, 2014, p. 181.

${ }^{97}$ Segue a versão original: Cette construction est, à mon avis, la plus simple de toutes celles qui ont esté inventées jusques à maintenant pour la solution de ce Probleme, duquel depend la duplication du Cube si celebre, \& qui a tant esté recherchée par les Geometres Anciens \& Modernes [...].Adições (AT, X, 653).

${ }^{98}$ Adições (AT, X, 653). Segue a versão original: Mais j'estime encore davantage celle qui suit, laquelle se fait par le moyen d'une seule parabole, du cercle, \& de la ligne droite [...].

${ }^{99}$ Cf. SHEA, 1993, p. 85.

${ }^{100}$ Cf. MERSENNE, 1636, p. 147
} 
diagrama, cabe a Roberval. A construção de Descartes, contudo, acompanha um comentário. Ei-lo:

\begin{abstract}
Seja, então, a linha $\mathrm{M}$ o lábio do sino, cuja metade é $\mathrm{N}$, e que encontrar-se-ão duas médias em proporção. Descreva-se a parte DA da parábola, cujo vértice $\mathrm{A}$ dista do foco $\mathrm{O}$ uma quarta parte duma linha dada, a saber de M. Em seguida, assuma-se o ponto B, que dista de $\mathrm{A}$ metade da linha $\mathrm{M}$, e, do ponto $\mathrm{B}$, prolongue-se em ângulo reto $\mathrm{BC}$, igual à metade de $\mathrm{N}$. E, por último, prolongue-se o círculo por $\mathrm{A}$, que cortará a parábola em $\mathrm{D}$, e prolongue-se da intersecção do ponto $\mathrm{D}$ uma perpendicular ao eixo $\mathrm{AE}$, da qual DI será a maior das médias, enquanto IA será a menor: cuja demonstração e muito mais esperaremos do seu inverntor. (GRIFO NOSSO) ${ }^{101}$
\end{abstract}

Na visão de Shea, Descartes temia que Mydorge, Mersenne e Roberval achassem o procedimento simples demais e escondia que $n$ não era senão o latus rectum ao dizer que $A O$ é igual a $\frac{1}{4} m$ em vez de $\frac{1}{2} n$.

Curiosamente, apesar de ter escrito uma breve demonstração, se é que assim podemos chamá-la, Descartes não a reconhece enquanto tal, pois diz estar à espera da demonstração. Talvez seja por isso que Mersenne diz que Descartes teria um um meio (moyen, modum) de resolução, mas não diz que ele tem a demonstração. Quanto a Roberval, devemos-lhe a demonstração. E o processo desse matemático na descoberta da demonstração Mersenne narra da seguinte maneira:

\begin{abstract}
Com efeito, quando o Professor do ramo das Ciências Matemáticas, Gilles de Roberval, no Colégio da França, examinou essa construção, primeiramente observou a simples construção do difícil problema de acordo com seu gênero; em seguida, quando examinava ao mesmo tempo atentamente a mesma, elaborou ex tempore uma demonstração dela, a qual eu introduzo, aproveitando a ocasião, nessa página. ${ }^{102}$
\end{abstract}

\footnotetext{
${ }^{101}$ No texto original: Sit igitur labrum campanae linea $M$, cuius dimidium $N$, quas inter hac ratione duae mediae reperientur. Parabolae pars DA describatur, cuius vertex A distet à foco $O$ quarta parte unius ex lineis datis, verbi gratiâ lineae $M$, deinde assumatur in axe parabolae punctum $B$ distans ab A dimidio lineae $M, \&$ ex puncto $B$ educatur ad angulos rectos $B C$ aequalis dimidio $N$ : denique ex centro $C$ per $A$ ducatur circulus, qui secet parabolam in $D$, \& ex $D$ puncto sectionis ducatur perpendicularis ad axem AE quae maior DI erit ex mediis, EA verò minor: cuius demonstrationem ab illius inventore cum aliis pluribus expectabimus. Cf. MERSENNE, 1636, p. 146-147. Deve-se observar que, no texto original, há um erro: EA deve ser lido como IA. Shea corrige em sua tradução, e aqui também corrijo, mas somente na tradução, preservando o erro na transcrição original. Cf. SHEA, 1993, p.84.

102 Segue a versão original: Hanc autem constructionem cum Aegidius de Roberval Mathematicarum scientiarum in Collegio Regio Franciae Professor Rameus inspexisset, primum quidem problematis ardui compositionem in suo genere sane simplicem miratus est; deinde cum ipsam tantisper attente speculatus esset, demonstrationem illius ex tempore adinvenit, quam ego, arrepta occasione, huic paginae inservi. Cf. MERSENNE, 1636, p. 147.
} 
$\mathrm{Na}$ versão francesa, Mersenne diz que Descartes, obviamente sem o citar nominalmente, forneceu apenas a construção, mas que a demonstração (que a Roberval pertence) pode ser encontrada facilmente. Ou seja, a construção que aparece na versão francesa, Roberval a atribui a Descartes, diferentemente do que diz Shea. Eis o comentário: "É verdade que ele [Descartes] nos deu somente a construção; mas não foi difícil encontrar a demonstração, ambas que se seguem." 103

Se se compara os dois diagramas (o da versão latina e o da versão francesa), observa-se uma ligeira diferença. E isso se dá porque o diagrama da versão francesa (figura 5) aparece adaptado aos passos demonstrativos de Roberval. Contudo, já na versão latina (figura 4), Mersenne sugere ao leitor a inserção de algumas retas, dando-lhe comandos de construção, a fim de facilitar a demonstração. Eis o comentário de Mersenne: "Uma vez que a figura fora elaborada para a mera construção, nela faltam algumas linhas para a demonstração, as quais o benigno leitor completará”. ${ }^{104}$

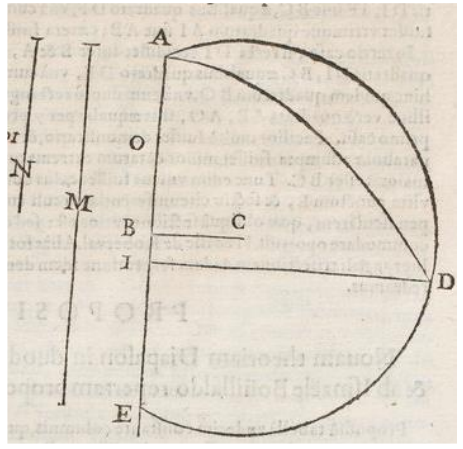

Figura 4 (MERSENNE, 1636, p. 147)

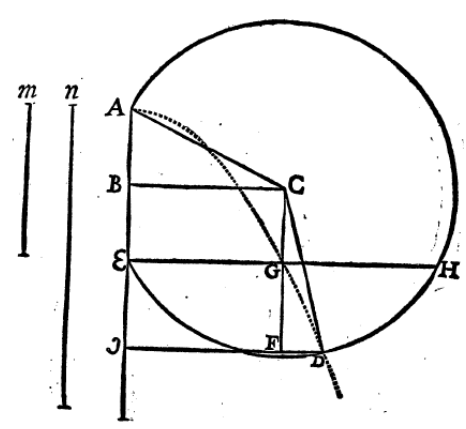

Figura 5 (MERSENNE, 1637, p. 410)

\footnotetext{
${ }^{103}$ Segue a versão original: Il est vray qu'il ne nous em a donné que la construction; mais il n'a pas esté difficile d'em trouver la demonstration, l'une \& l'autre desquelles est comme s'ensuit. Adições (AT, X, 653).

104 Segue a versão original: Quia vero figura ad constructionem nudam elaborata fuerat, desunt illi ad demonstrationem quaedam lineae, quas suppeblit benignus Lector. Cf MERSENNE, 1636, p. 147.
} 


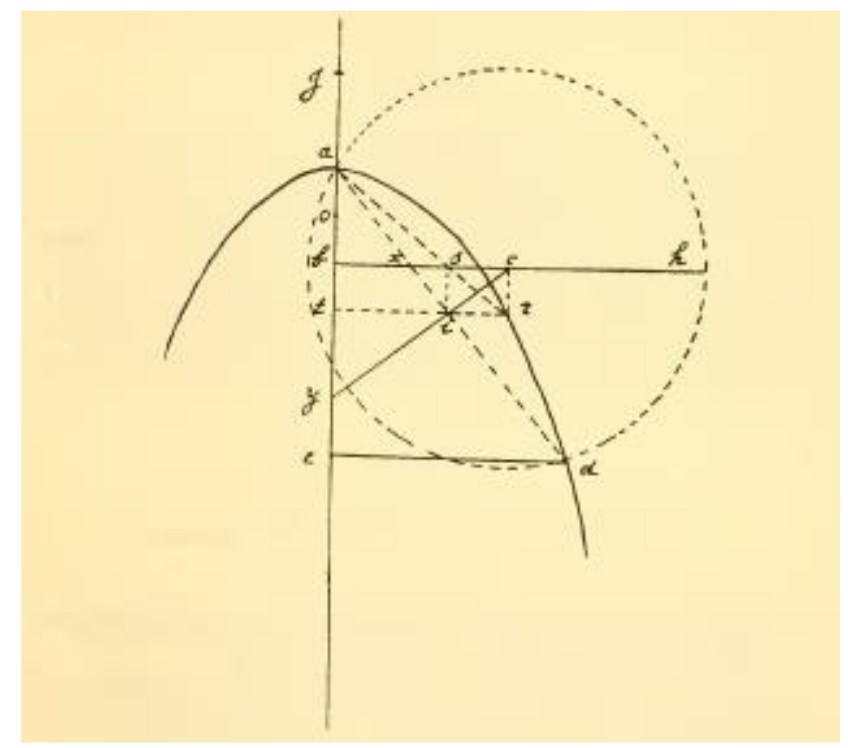

Figura 1 (AT, X, 343)

\section{5}

\section{Comentário às demonstrações}

Pelos motivos apresentados acima, é possível destacar duas características da prova de Roberval que não devem de fato ter agradado a Descartes e que apontam em sentido negativo duas características do seu modo de proceder nas demonstrações.

A primeira delas, e que parece ser a mais problemática, consiste no fato de a demonstração ser um caso especial de duas médias proporcionais; e, por isso mesmo, pode-se dizer que há uma deficiência na generalidade da prova. O próprio Mersenne indica que, para a demonstração ser "universal", é necessário que se somem os casos: "Em seguida para que a demonstração seja universal, três são os casos". ${ }^{105}$ No primeiro caso, por exemplo, as duas retas ( $m$, que é o latus rectum, e $n$ ) não podem ter valores arbitrários, uma vez que $n$ é igual a $2 m$; ou ainda, como se vê no segundo caso, $n$ é igual a $8 m$. A demonstração de Mydorge, por outro lado, pode ter valores arbitrários para ambos os lados, contanto que sejam

${ }^{105}$ No original: Deinde ut demonstratio sit universalis, tres sunt casus [...].Cf. MERSENNE, 1636, p. 147 . 
desiguais, ou seja: um deles é maior do que o outro. Assim, é por esse motivo que Sasaki faz a seguinte observação: "A solução de Mydorge era geral no sentido em que as duas linhas dadas eram arbitrárias". 106

A segunda delas tem a ver com certas exigências da configuração do próprio diagrama, adotadas por Roberval. O fato de a parábola, na figura 5, cortar a reta $\mathrm{EH}$ e o ponto $\mathrm{D}$ da circunferência, isto é, um critério de invariabilidade do diagrama, é na verdade um empecilho da prova, pois motiva uma multiplicação de casos (ou "case-branching" na literatura anglófona). Ao considerarmos a prova de Roberval, vê-se que surgem um segundo e um terceiro caso: “Au second cas, quand la perpendiculaire $\mathrm{CF}$ tombe au point $\mathrm{D}$ " e "Au troisiesme cas, quand la perpendiculaire CF tombe sur ID prolongee au delà de D”. Na prova de Mydorge, que se utiliza de semelhança de triângulos, além de ser um resultado geral, não há a necessidade de somar resultados singulares a fim de se obter a generalidade da prova. A deformação diagramática é patente quando se observa o comentário de Mersenne, citado acima, que apela à benignidade do leitor, e sugera a descrição de novas retas (figura 4): "São, então, as retas de C a A, C a D, de E, perpendicular à reta $\mathrm{AE}$, e de $\mathrm{C}$, perpendicular à reta $\mathrm{ID}$, que é $\mathrm{CF}^{\prime 107}$. Quando se fixa os olhos no diagrama com suas respectivas alterações, e, ato contínuo, se observa o diagrama, reelaborado por Mersenne (figura 5), nota-se uma clara deformação do diagrama, que não significa de modo algum uma invalidação das informações contidas na figura e que não traz consigo nenhum impedimento ou falha na demonstração. O mesmo não se pode dizer da demonstração de MydorgeDescartes, que depende, impreterivelmente, de uma configuração sem deformidades. Dessa maneira, podemos dizer que a configuração da construção de Roberval implica em uma multiplicação de casos, que acaba por aumentar a extensão da prova. Notamos, portanto, que esses dois aspectos, conectados entre si, da prova de Roberval podem ter parecido negativos a Descartes, além de serem um contra-exemplo ao modo de proceder nas demonstrações de Descartes, o que ficará mais claro nos próximos parágrafos, em especial a partir da citação do trabalho de Manders.

106 Cf. SASAKI, 2003, p. 171. Sasaki também chama a atenção para o enunciado (Problema solidum solide [verdadeiramente] constructum) como um sinal da generalidade da prova.

${ }^{107}$ No original: Sunt autem illae rectae ex $C$ in $A$, ex $C$ in $D$, ex E perpendicularis ad rectam $A E$, atque ex C perpendicularis ad rectam ID, quae sit, Cf. MERSENNE, 1636, p. 147. 
Antes de passarmos ao ponto seguinte, é necessário chamar a atenção que, de fato, Descartes manifesta uma preferência pela generalidade das provas e rejeita a multiplicação de casos, preferindo provas mais curtas. E, ademais, chega a apontar que a causa das provas longas e a não generalidade das provas são consequências da prática de alguns matemáticos (chamados de "pequenos Geômetras"), justamente porque aplicam teoremas euclidianos na resolução de problemas que lhes são apresentados. Vejamos seu comentário em uma carta a Elisabeth:

\begin{abstract}
Pois me parece que o dispensável, que consiste em procurar a construção \& a demonstração pelas demonstrações de Euclides, escondendo o procedimento da Álgebra, não é senão um divertimento para os pequenos Geômetras, que não requer muito do espírito nem da ciência. Mas se há alguma questão que se quer solucionar, para se elaborar um Teorema que serve de regra geral para resolver muitos outros parecidos, é necessário reter ao fim todas as mesmas letras que foram postas no começo; ou bem, se se troca alguns para facilitar o cálculo, é preciso colocá-los em seguida, estando ao fim, porque ordinariamente muitos se apagam um contra o outro, o que se pode ver, quando são trocados.

É bom, portanto, também observar que as quantidades que se denomina por letras, tendo uma relação semelhante uns com os outros, o quanto possível; isso torna os Teoremas mais belos e mais curtos, porque o que se enuncia de uma dessas quantidades enuncia-se do mesmo modo dos outros, \& impede que se possa falhar no cálculo, porque as letras, significando as quantidades que têm a mesma relação, devem se encontrar distribuídas do mesmo modo, \& quando se falta isso, reconhece-se seu erro. (GRIFO NOSSO) ${ }^{108}$
\end{abstract}

É verdade que, quando da carta a Elisabeth, Descartes já dispunha de métodos algébricos. Porém, há algumas observações nesse trecho que se destacam e que podem esclarecer as preferências demonstrativas de Descartes na época das discussões do problema das duas médias proporcionais. Em primeiro lugar, vemos um desprezo pela prática que visa conciliar a resolução de um dado problema

\footnotetext{
108 Segue a versão original: Car il me semble que le surplus, qui consiste à chercher la construction \& la demonstration par les propositions d'Euclide, en cachant le proceder de l'Algebre, n'est qu'un amusement pour les petits Geometres, qui ne requiert pas beaucoup d'esprit ny de science. Mais lors qu'on a quelque question qu'on veut achever, pour en faire un Theoreme qui serve de regle generale pour en soudre plusieurs autres semblables, il est besoin de retenir iusques à la fin toutes les mesmes lettres qu'on a posées au commencement; ou bien, si on en change qualques-unes pous faciliter le calcul, il les faut remettre par apres, estant à la fin, à cause qu'on ordinairement plusieurs s'effacent l'une contre l'autre, ce qui ne se peut voir, lors qu'on les a changées. Il est bon aussi alors d'observer que les quantitez, qu'on on denomme par les lettres, ayent semblable rapport les unes aux autres, le plus qu'il est possible; cela rend le Theoreme plus beau \& plus court, pour ce que ce qui s'enonce de l'une de ces quantitez, s'enonce en même façon des autres, \& empesche qu'on ne puisse faillir au calcul, pour ce que les lettres qui signifient des quantitez qui ont mesme rapport, s'y doivent trouver distribuées en mesme façon ; \& quand cela manque, on reconnoist son erreur. Carta de Descartes a Elisabeth de novembro de 1643 (AT, IV, 47).
} 
matemático com os teoremas da geometria euclidiana. Tal procedimento é, então, contrastado com outra prática matemática que busca a transformação dos elementos do problema geométrico em letras, e, em seguida, em equações algébricas. Trata-se, pois, do próprio método algébrico. ${ }^{109}$

Com efeito, a simbolização algébrica tem três consequências: a elaboração de "regras gerais" (o que significa a descoberta de resoluções mais gerais, ou universais), provas mais curtas e certa facilidade na identificação de algum erro. E, pode-se adicionar, por fim, que há uma dimensão estética da prova, pois as provas algébricas são, curiosamente, consideradas por Descartes mais belas. Com efeito, o impedimento da multiplicação de casos graças à tradução do problema geométrico em uma formulação algébrica encontra-se em outra carta a Elisabeth, já citada, e onde ele mostra uma preferência pelos "caminhos mais curtos", livrando-se das tais "multiplicações supérfluas", que podemos ilustrar com a multiplicação de casos da prova de Roberval de duas médias proporcionais. ${ }^{110}$

\section{6}

\section{Roberval e o livro II d'Os Elementos}

109 Há outro trecho no livro d'A Geometria que parece corresponder a esse procedimento. Vejamos: “Assim, querendo resolver algum problema, deve-se, inicialmente, considerá-lo como já feito, e dar nomes a todas as linhas, que parecem necessárias para a construção, tanto àquelas que são desconhecidas como àquelas que não o são. Em seguida, sem considerar que haja alguma diferença entre as linhas conhecidas e as desconhecidas, deve-se examinar a dificuldade segundo a ordem que mostra mais naturalmente de que maneira elas dependem mutualmente umas das outras, até que se tenha encontrado um meio de exprimir uma mesma quantidade de dois modos: esse que se chama equação; pois os termos de uma de seus dois modos são iguais aos [termos] do outro. E deve-se encontrar tantas equações quantas foram as linhas supostas desconhecidas. Ou então, se não se encontra, e que não obstante não se omite nada que é desejado na questão, isso mostra que ela [equação] não está completamente determinada. E então se pode escolher as linhas conhecidas como se queira para todas as desconhecidas que não correspondem à nenhuma equação. Depois disso, se nos resta ainda muitas [linhas desconhecidas], é preciso se servir, por ordem, de cada uma das equações que restam, seja considerando-a separadamente, seja comparando-a com as outras, a fim de explicar cada uma das linhas desconhecidas e [...]." $A$ Geometria (AT, VI, 372) Casanave elabora um comentário acerca do método proposto por Descartes, que pode ser dividido em três etapas, a saber: nomear, equacionar e construir geometricamente. As duas primeiras etapas fazem parte da análise, enquanto a terceira faz parte do momento sintético (ou de construção). Segundo Casanave, as etapas do procedimento metodológico cartesiano, que ele e Mancosu chamam de nomear e de equacionar, e que podem ser ilustrados pela citação acima da carta e d'A Geometria, consistem respectivamente em "substituir as quantidades conhecidas e desconhecidas do problema por diferentes tipos de signos" e "em expressar a(s) magnitude(s) desconhecida(s) em função das conhecidas, o qual se alcança por manipulação regrada de signos algébricos.” Cf. CASANAVE, ainda não publicado, p. 52 e também MANCOSU, 1996, p. 67-68.

${ }^{110}$ Cf. Carta de Descartes a Elisabeth de novembro de 1643 (AT, IV, 38). 
Shea constatou, de pronto, em um contraste entre a demonstração Mydorge-Descartes e a de Roberval, o fato de a primeira apoiar-se sobre semelhança de triângulos, enquanto Roberval aplica demonstrações do livro II d'Os Elementos, de Euclides. Ainda não ficou clara a razão de Roberval ter escolhido as construções do livro II como apoio numa prova que envolve uma seção cônica.

Zeuthen observou que, no tratamento das cônicas, Apolônio de Perga empregava dois "métodos auxiliares", ambos retirados d'Os Elementos, que são: a teoria das proporções (livros V e VI) e o livro de paralelogramos (livro II) tratando-se, na visão do especialista, tanto um quanto o outro de métodos algébricos. ${ }^{111}$ Assim, a geometria antiga tornava implícitas as operações algébricas, camufladas sob a aparência de construção geométrica. Van der Waerden, na mesma esteira interpretativa de Zeuthen, por exemplo, distingue, nas cônicas de Apolônio, aquilo que chama de o "digrama geométrico" (a seção cônica propriamente dita) do "diagrama algébrico" (os retângulos, que funcionariam como construções auxiliares nas demonstrações acerca das propriedades das cônicas). ${ }^{112}$

Contudo, a partir de uma crítica iniciada por Unguru a essa posição de Zeuthen, Saito discorda da interpretação que se consolidou na historiografia passada, enfatizando, por isso mesmo, a matemática de Apolônio como uma geometria de figuras ou sintética, e não interpretando o livro II de Euclides como uma "álgebra geométrica". Um dos problemas alegados por Saito é a constatação de que algumas proposições do livro II d'Os Elementos podem ser expressas numa única fórmula algébrica, e. g.: as proposições II. 5 e II.6, que equivalem a $(a+b)(a-b)=a^{2}-b^{2}$, valendo o mesmo para II.9 e II.10 ou II.4 e II.7. A forma dupla dessas proposições reforçaria a argumentação de Saito, uma vez que

\footnotetext{
${ }^{111}$ Na visão de Mahoney, Petrus Ramus foi o primeiro a enxergar nas nalgumas partes do livro II e VI uma álgebra subjacente. A prova de sua tese consiste no fato de Ramus utilizar exemplos numéricos de proposições desses livros. Ramus assim procede no seu Geometriae libri septem et viginti (1659). Mahoney também chama a atenção para a seguinte observação: "[...] esse uso permanece na análise geométrica" ([...] hic geometriae analyseos usus superest), isto é, de que a álgebra subjazeria a análise geométrica. Cf. MAHONEY, 1970, p. 148, nota 39. Unguru, contudo, aponta que esse crédito a Ramus é duvidoso. Cf. UNGURU, 1975, p. 69, nota 6.

${ }^{112}$ Cf. VAN DER WAERDEN, 1975, p. 247.
} 
a complementação mútua delas é apropriada ao contexto geométrico, que depende do arranjo espacial de pontos e linhas. ${ }^{113}$

Enfatizando o caráter essencialmente geométrico do livro II e a distinção entre as considerações firmadas sobre as relações espaciais dos objetos geométricos e as considerações abstrativas da álgebra, Roque diz o seguinte:

\begin{abstract}
A abordagem algébrica se caracteriza pela abstração de características comuns a objetos de diferentes naturezas, o que possibilita que sua estrutura comum seja representada por símbolos. [...]
\end{abstract}

Ainda que as proposições do livro II dos Elementos possam ser
interpretadas algebricamente, suas demonstrações são essencialmente
geométricas e utilizam as propriedades geométricas particulares das
figuras em questão. Nada sinaliza que Euclides estivesse usando
relações abstratas entre quantidades, além disso suas demonstrações
não utilizavam nenhuma das propriedades das operações algébricas. ${ }^{114}$ Assim, aproveitaremos o argumento de Saito para constatar que na resolução de Roberval, dada a configuração inicial, apresentada por Descartes, ser-lhe-ia impossível, por exemplo, cambiar a proposição II.7, $(a+b)^{2}+a^{2}=$ $2(a+b) a+b^{2}$, a utilizada na demonstração, pela II.4, $(a+b)^{2}=a^{2}+b^{2}+$ $2 a b$ - algebricamente equivalente à primeira. A demonstração de Roberval é, na verdade, puramente geométrica. A despeito do comentário acerca do livro II d'Os Elementos, encontramos já no comentário de Mersenne a perspectiva de que se trata de uma demonstração geométrica, e não algébrica: "eu quero aqui adicionar um meio de encontrá-las [as médias proporcionais] Geometricamente”. ${ }^{115}$

Além do mais, reforça-se, a partir do comentário de Saito e de Roque, a ideia de maior generalidade expressa na demonstração de Mydorge-Descartes, que não se serve do livro II. Afinal, as construções euclidianas do livro II fariam a demonstração depender da disposição dos objetos geométricos. A demonstração de Mydorge, por outro lado, que utiliza como construção auxiliar a proporção entre triângulos, permite uma rápida conversão do objeto geométrico exposto

\footnotetext{
${ }^{113}$ Saito diz o seguinte: "Eu afirmo que o objeto do argumento no segundo livro d'Os Elementos não é quantidades em geral. As áreas e comprimentos de linhas são sempre consideradas e tratadas conjuntamente com posições". Cf. SAITO, 1985, p. 157.

${ }^{114}$ Cf. ROQUE, 2012, p. 111.

115 No original: [...] ie veux icy adiouster un moyen de les trouver Geometriquement [...] Cf. MERSENNE, 1637, p. 408. Na tradução da demonstração de Roberval, que se encontra no apêndice, pusemos notas explicando algebricamente os passos de Roberval. Porém, devemos lembrar que não fazem parte da demonstração original, que tem caráter geométrico.
} 
(com uma parábola e um círculo) numa equação algébrica e, portanto, goza de uma maior universalidade.

\section{7}

\section{O exato versus o co-exato: uma interpretação de Manders}

Cada passo da prova euclidiana deve ser justificado a partir de uma alusão a algum elemento anterior (seja às proposições indemonstráveis, seja a outra prova já exibida), ou ainda à configuração do diagrama em questão. Esse conjunto de fatores que sintetizam componentes linguísticos e a visualização diagramática leva as provas euclidianas a serem chamadas de heterogêneas. Manders, em seu esforço de compreensão do funcionamento da intervenção do diagrama na prova, chegou a uma terminologia que nos ajuda na compreensão de como Euclides articula as informações diagramáticas e como elas são legitimadas em seu sistema geométrico.

As informações diagramáticas e que podem ser levadas em consideração nas estratégias demonstrativas da matemática não são todas elas iguais. Segundo a terminologia de Manders, há uma distinção entre o que ele chama de aspecto exato e co-exato. Quanto ao primeiro, trata-se de uma informação que resiste à variação ou deformação do diagrama, e que envolve, por exemplo, relações de parte e todo das regiões do diagrama (não importando quão deformados e deslocados estejam os contornos dos diagramas) ou ainda a existência de pontos que emergem a partir de uma intersecção de diagramas. Alguns casos que podem ser observados em Euclides. Citemos três exemplos. Primeiramente, a proposição I.1, na qual, por piores que sejam descritos os círculos, o ponto $C$ aparecerá. Em segundo lugar, na proposição I.32, onde, por pior que seja traçada uma paralela ao lado do segmento, o ângulo externo será dividido em dois. E por último, na proposição III.6, onde, por pior que seja o desenhista, os raios o segmento $Z E$ será parte do segmento $Z B .{ }^{116}$

Quanto aos atributos exatos, tratam-se daquelas informações explicitadas na própria configuração das construções que "são, por definição, instáveis ante a

\footnotetext{
${ }^{116}$ Vide a demonstração da proposição I.1 que foi apresentada no primeiro capítulo desse trabalho. Casanave explora os três exemplos que menciono. Cf. LASSALLE CASANAVE, a ser publicado, p. 33.
} 
perturbação do diagrama" ${ }^{117}$, por exemplo, igualdade ou proporcionalidades. São citados como ilustração alguns casos onde há a igualdade de segmentos ou ângulos, a congruência de triângulos e a proporcionalidade de retas.

Devemos acrescentar que Manders enxerga nas demonstrações euclidianas os atributos co-exatos, enquanto vê na abordagem ao diagrama da geometria cartesiana os atributos exatos, que desde Descartes, ao menos, podem ser expressos por equações algébricas. ${ }^{118}$ Dessa forma, ele contrasta o raciocínio euclidiano, fundado nos diagramas, com aquele dos diagramas da geometria analítica de Descartes. A sua tese é que a geometria cartesiana tem elementos que lhe permite se apoiar somente sobre atributos exatos através do uso de equações polinomiais, eliminando atributos co-exatos (inequações polinomiais). Manders resume o procedimento da geometria cartesiana assim: “[...] manipulação algébrica, talvez aliada a construções geométricas iniciais, é suficiente para derivar a equação do problema”. ${ }^{119}$

Essa divisão entre informações geométricas exatas e co-exatas é útil a Manders, pois permite a explicação segundo a qual Euclides se serviria legitimamente dos diagramas. E uma vez que os passos probatórios em que Euclides é, em geral, acusado de se apoiar na visualização do diagrama, seriam aspectos co-exatos, isto é, seriam considerações que resistem à deformação do diagrama. Assim, ao menos, a acusação de que os diagramas são imperfeitos ou deficientes cairia por terra. Nas palavras de Manders: "Falhas típicas em Euclides envolvem a leitura de alguns aspectos co-exatos de um diagrama; e isso é permitido." 120 A conclusão do especialista é que o raciocínio baseado nos diagramas de Euclides é seguro e usá-los como justificativa é adequado, não comprometendo a confiabilidade no diagrama.

\footnotetext{
${ }^{117}$ Cf. MANDERS, 1995, p. 93.

118 Cf. MANDERS, 1995, p. 92. Convém lembrar que Manders identifica na geometria de Descartes quatro marcas da introdução da álgebra de sua geometria, a saber: a igualdade, a adição de segmentos, proporcionalidades a partir de similaridades e o teorema pitagórico. Como mostra Manders, essas marcas são encontradas explicitamente na carta, já citada, a Elisabeth (AT, IV, 3839), onde Descartes cita uma série de passos na resolução de questões (isto é, problemas matemáticos a serem resolvidos), e são anunciadas previamente, segundo ele, nas Regras (AT, X, 381-2), onde, precisamente na regra VI, Descartes enumera alguns elementos contidos nas questões (por exemplo: o igual, o semelhante e o reto). Cf. MANDERS, ainda não publicado, p. 14.

${ }^{119}$ Cf. MANDERS, 2008, p. 76.

${ }^{120}$ Cf. MANDERS, 1995, p. 91.
} 
O que Manders chama de "tradição lógica" havia visto o ponto $C$ que surge da intersecção dos círculos, na proposição euclidiana I.1, uma falha na prova tradicional. Mas, é preciso reconhecer que a informação obtida a partir do diagrama não está de nenhum modo subordinada à imperfeição da figura, uma vez que no diagrama encontramos, nas palavras do próprio Manders, "condições que são indiferentes aos efeitos de uma gama de variações”; e prossegue: "Quando nós distorcemos os "círculos" em I.1, a intersecção deles no ponto C pode deslocar-se, mas não desaparecer". ${ }^{121}$ Assim, ainda que a figura fosse desenhada de modo imperfeito, o ponto que surge da intersecção dos círculos em I.1 emergiria necessariamente pela simples intersecção dos dois círculos; e a conclusão de que há um triângulo equilátero continuaria a ser obtida, ainda que um círculo com uma aparência oval fosse traçado, graças à definição I.15 (do círculo) e a noçãocomum I.1, e não ao talento artístico do matemático.

Dito isto, direcionaremos nossos esforços em conciliar essas distinções com o que de fato pensavam os matemáticos envolvidos rede de elaboração da resolução do problema das duas médias proporcionais. E embora Manders não tenha se dedicado à análise desse problema em particular, cremos que seu quadro conceitual pode ser útil na compreensão do que está em jogo, especialmente quanto ao papel do diagrama na matemática de Descartes.

À primeira vista, não encontramos nenhuma observação que venha a endossar ou contrariar as distinções contemporâneas entre aspectos exatos e coexatos. Não obstante, se se considera os comentários de Frans van Schooten, deparamo-nos com uma curiosa comparação entre os diagramas das duas médias proporcionais, tratados anteriormente, e a proposição I.1 de Euclides. Expliquemos a comparação: Schooten considera o ponto que surge da intersecção de dois círculos, na prova euclidiana, uma configuração semelhante àquele que surge da intersecção da parábola e do círculo, na geometria cartesiana. O comentário é direcionado àqueles que questionavam a cientificidade das demonstrações euclidianas (a exemplo da proposição I.1), que como já mostramos, se sustentavam nas informações diagramáticas. Estes, então, ao observar as construções cartesianas em que há intersecção de parábola e círculo,

${ }^{121}$ Cf. MANDERS, 1995, p. 69. 
chegariam à mesma conclusão. Schooten, porém, discorda. Consideremos o comentário do matemático holandês:

[...] contudo, desaprovaram a descoberta de Menêcmo das duas médias por Parábola e Hipérbole, ou ainda pela intersecção de duas Parábolas, como geométrica. E esta, a meu ver, não calha de ser considerada menos geométrica que aquela que é asserida por Euclides no Problema I.1 dos Elementos: com efeito, o ponto, no qual as secções se encontram não se demonstra de modo menos científico, para que seja descrito o triângulo equilátero. ${ }^{122}$

O comentário, todavia, parece desmentir a posição de Manders acerca dos aspectos exatos e co-exatos (que são relacionados, respectivamente, com a geometria cartesiana e euclidiana). Manders, com efeito, pensa que a intersecção (como ocorre, por exemplo, em I.1) é uma marca estrita de aspecto co-exato do diagrama. Porém, notamos que, nas demonstrações de Descartes, especialmente as que envolvem construções de equações do terceiro e quarto graus em diante (apresentadas no terceiro livro d'A Geometria), há o surgimento de pontos por meio da intersecção de curvas, os quais são fundamentais, pois expressam as raízes da equação (vide os diagramas que envolvem a construções de duas médias proporcionais).

Para sermos mais precisos, convém ressaltar que Manders, como é esclarecido no seu artigo ainda inédito, reconhece a articulação simultânea de informações exatas e co-exatas na geometria euclidiana. Além do mais, ele também a reconhece no caso da matemática cartesiana, salientando, contudo, que Descartes extrai resultados notáveis das informações exatas. Desse modo, não se trata de um antagonismo irreconciliável. Em ambas as estruturas diagramáticas (cartesiana e euclidiana) encontramos um misto de aspectos exatos e co-exatos. Contudo, esses aspectos são destacados dependendo do estilo de proceder nas provas de cada autor.

De fato, eu utilizei ED para contrastar com a geometria analítica de Descartes e versões seguintes. Uma grande diferença: geometrias analíticas têm recursos expressivos que permitem certas inferências irrefutáveis baseadas somente em informação geométrica exata (utilizando equações polinomiais) de modo separado da informação

\footnotetext{
${ }^{122}$ No original: [...] ac proinde Menaechmi inventionem duarum mediarum per Parabolae \& Hyperbolae, sive etiam per binarum Parabolarum intersectionem, veluti non Geometricam respuunt. Quam sanè (meo judicio) non minùs Geometricam censere oportet, quam illam, quae ab Euclide affertur in Problema $1^{\wedge}$ mum Libri $1^{\wedge}$ mi Elementorum: siquidem punctum, in quo hae sectiones sibi mutuò occurrunt, non minùs scientificè invenitur, quàm illud, in quo bini circuli se invicem intersecant, ad describendum triangulum aequilaterum. Cf. VAN SCHOOTEN, 1649, p. 183.
} 
co-exata (desigualdades polinomiais); o raciocínio euclidiano fundado nos diagramas requer ambos ao mesmo tempo. ${ }^{123}$

Levando em consideração a observação de Schooten e o conjunto dos elementos conceituais advogados por Manders, pensamos ser possível avançar em mais algumas distinções, que, ao fim da análise, acabarão por endossar a posição de Manders. É preciso admitir que, de fato, quanto às construções cartesianas, há algo nelas que guardam as características do aspecto exato de diagramas. Isso que conserva as informações exatas do diagrama, na verdade, são as construções auxiliares, e não o diagrama como um todo. Esse conjunto de construções, por sua vez, permite a descrição algébrica de curvas.

E, ainda que Manders cite a geometria cartesiana como paradigma do raciocínio diagramático baseado nos aspectos exatos e mesmo trate dalgumas demonstrações que aparecem no texto cartesiano, não analisa o caso em questão (isto é, das duas médias proporcionais). Contudo, tomamos a liberdade de exemplificar o conceito de Manders, com o objetivo de apontar o papel das construções auxiliares na geometria cartesiana, que guardam aspectos exatos.

Assim, no livro II d'A Geometria: há a construção de uma curva por meio de um esquadro deslizante e de uma régua rotatória. A curva é sabidamente uma hipérbole. Contudo, ela é conhecida a partir da sua expressão algébrica, que, por sua vez, só é obtida porque se recorre a uma relação proporcional entre triângulos. Como foi dito acima na explicação das distinções de Manders, o apelo a relações proporcionais, exposto no exemplo que se segue, é uma marca indissociável dos aspectos exatos. Observemos, pois, a demonstração:

${ }^{123}$ Cf. MANDERS, 2008, p. 76. 


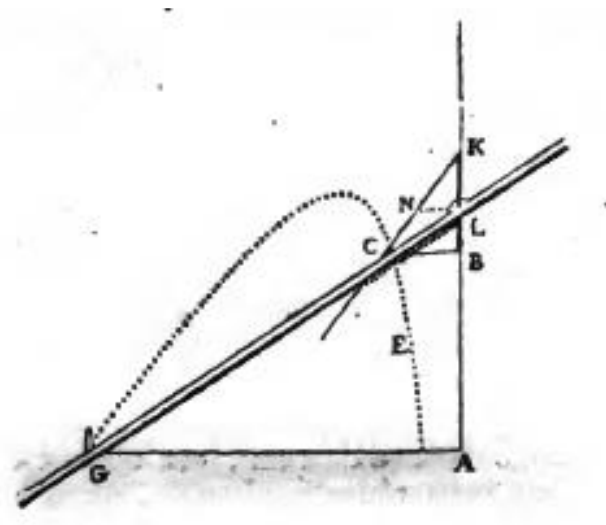

Figura 6 (AT, VI, 393)

A equação que descreve esta hipérbole, $y^{2}=c y-\frac{c x}{b} y+a y-a c$, pode ser encontrada a partir da relação entre dois triângulos semelhantes $N L K$ e $C B K$, isto é: $\frac{N L}{L K}=\frac{C B}{B K}$, sendo $N L=c, L K=b$ e $C B=y$, portanto $B K=\frac{b}{c} y, B L=\frac{b}{c} y-b$ e $A L=x+\frac{b}{c} y-b$. Em seguida, é possível estabelecer uma relação de semelhança entre os triângulos $C L B$ e $G L A$, (isto é: $\frac{C B}{B L}=\frac{G A}{A L}$, sendo $G A=a$ ), alcançando-se dessa maneira a equação da hipérbole supracitada.

Eis como a combinação de construções auxiliares, que expressam semelhança de triângulos e às quais sãos atribuídos valores algébricos, acaba por definir a equação algébrica da construção principal em questão. O que revela a equação da hipérbole desse caso é o grupo de construções subordinadas que justamente preenchem o pré-requisito do conceito de aspecto exato do diagrama. Do ponto de vista da demonstração, os resultados da geometria cartesiana consistem numa focalização exercida $\mathrm{n}$ o conjunto de dados que podem ser retirados, sobretudo, das partes exatas do diagrama.

Essas características são plenamente contrastadas com a estratégia demonstrativa escolhida por Roberval, que vimos anteriormente. Decerto, a escolha de Roberval coaduna-se com uma estrutura demonstrativa muito mais próxima àquela de Euclides, utilizando-se ele mesmo de um teorema euclidiano como construção auxiliar na sua resolução do problema, e, portanto, refletindo uma absorção de elementos co-exatos.

Voltemos, então, às considerações iniciais que motivaram a observação das distinções de Manders, isto é, a comparação entre as demonstrações de duas 
médias proporcionais de Mydorge-Descartes e Roberval. Percebemos que o mesmo modo de operar nas demonstrações, que foi exemplificada acima, se reproduz na demonstração de Descartes, o qual opera por relações proporcionais. Roberval, por outro lado, se serve de Euclides, cujas construções, segundo Manders, guardam aspectos co-exatos. Com efeito, a construção das duas demonstrações é grosso modo a mesma, isto é: envolve a intersecção de uma parábola e de um círculo. Entretanto, eles se diferenciam no modo como se servem de construções auxiliares. É inegável e acertada a afirmação de que as construções auxiliares de Mydorge-Descartes são exatas, enquanto as de Roberval são co-exatas - já que, como bom entusiasta da geometria euclidiana, esse se utiliza do livro II d'Os Elementos, e, portanto, de aspectos co-exatos do diagrama.

A partir da análise dessas demonstrações, cremos que a tese geral de Manders se confirma. Há, de fato, elementos co-exatos e exatos na geometria cartesiana, sendo esses últimos que mais interferem nas suas demonstrações. Contudo, o comentário de Schooten nos permite enxergar uma hierarquia mais clara entre esses elementos articulados nas provas cartesianas. Ao que tudo indica, os aspectos exatos do diagrama correspondem às construções auxiliares, enquanto os elementos co-exatos incarnam-se na construção principal. As tais construções auxiliares, que no caso estudado aparece sob a forma de semelhança de triângulos, favorecem à formulação algébrica da construção, denunciando como devemos classificar a curva e que construções são adequadas para a sua resolução.

Manders reconhece que a consciente limitação do diagrama cartesiano a uma estratégia demonstrativa que privilegia aspectos exatos do diagrama acaba por enriquecer a geometria tradicional com um novo método. ${ }^{124}$ Com efeito, o método matemático de Descartes preza muito mais pela determinação da complexidade construtiva do que pela apresentação ou pela resolução geométrica dos problemas. ${ }^{125}$ Isso explica, na visão de Manders, a valorização dos aspectos exatos nos diagramas cartesianos.

Deve-se, porém, chamar a atenção para o fato de Descartes não ter usado álgebra na resolução do problema. O resultado, todavia, pode ser facilmente

${ }^{124}$ Cf. MANDERS, a ser publicado, p. 14.
${ }^{125}$ Cf. MANDERS, a ser publicado, p. 19. 
formulado algebricamente. E não só o pode como ele também o fez n’A Geometria. Lá Descartes retoma o resultado exatamente numa versão algébrica. E, como veremos, alguns comentadores discutem a possibilidade de Descartes já ter em mãos um método algébrico nos idos da publicação no jornal de Beeckman. Contudo, como veremos essa tese parece pouco provável.

A constatação de tal distinção do papel do diagrama no mecanismo de prova de Descartes e de Roberval impele-nos à aceitação também de suas consequências. A confirmação da tese de Manders e da adoção de sua terminologia acarreta num corolário. A utilização de estruturas exatas (nas construções auxiliares) permite à demonstração Mydorge-Descartes dois ganhos, que são uma marca do modus modo de proceder nas demonstrações matemáticas de Descartes, podendo ser exemplificados n'A Geometria de Descartes com inúmeras provas. São eles: a abreviação dos passos da demonstração (em oposição à multiplicação ou ramificação de casos, que ocorre na demonstração de Roberval) e, em segundo lugar, a maior generalidade da prova (uma vez que facilita a generalização de segmentos), já apontados e discutidos com a devida referência aos diagramas.

Manders explica essa maior generalidade dos resultados obtidos nas demonstrações cartesianas ao fato de a representação simbólica permitir uma manipulação dos valores das quantidades indiferentemente. Demos as palavras a Manders: “Apoiado na manipulação da notação algébrica, ao invés de avaliá-las geometricamente em um diagrama, incógnitas, quantidades conhecidas, e coeficientes formados a partir deles são tratados indiferentemente em relação às magnitudes geométricas." ${ }^{126} \mathrm{O}$ fato de a demonstração Mydorge-Descartes adotar a semelhança de triângulos e estabelecer relações proporcionais entre segmentos, que são estruturas diagramáticas exatas e que podem ser facilmente convertidas em expressões algébricas, garante a ela maior generalidade e evita a multiplicação de casos. Ambas estão, segundo a posição de Manders, relacionadas entre si. Como reconhece Manders, a álgebra possibilita não só a generalização de segmentos, mas também elimina a multiplicação de casos. ${ }^{127}$ Segundo a posição

\footnotetext{
${ }^{126}$ Cf. MANDERS, a ser publicado, p. 23.
}

${ }^{127}$ Cf. MANDERS, 2008, p. 77. 
de Manders: “[...] os futuros métodos algébricos e de cálculo estabelecem a maior parte das vezes casos abreviados automaticamente". ${ }^{128}$

Se por um lado, as estruturas exatas levam a uma maior generalidade da prova; por outro, o estilo de prova Mydorge-Descartes não permite a deformação do diagrama. É, por esse motivo, que Roberval elabora sua prova a partir do diagrama estabelecido, sem se importar com a deformação do diagrama, diferentemente da demonstração Mydorge-Descartes. A demonstração de Descartes, se acaso fosse deformada, teria a visualização das relações proporcionais impedida, impossibilitando a prova. Não sem razão, para que a demonstração funcione, Descartes e Mydorge tiveram de alterar a configuração mesma do diagrama. Roberval, em contrapartida, não o precisa fazer, pois os aspectos co-exatos com os quais trabalha são capazes de suportar a deformação da figura.

Chegamos a uma conclusão depois da análise. O caso das duas médias proporcionais nos parece uma clara ilustração de como a eliminação da multiplicação de casos pode se dar a partir da operação de um modelo cartesiano sobre os diagramas. Para confirmá-lo, basta-nos compará-la à prova de Roberval, que se divide em três demonstrações, e que demanda também três diagramas. Por fim, esse problema matemático, embora não tenha sido comentado, por Manders, aponta para a confirmação da sua tese também acerca da multiplicação dos casos, próprio do modelo diagramático euclidiano, mas que é superado por Descartes.

\section{8}

\section{A influência de Mydorge}

Havendo Mydorge colaborado para a elaboração da demonstração, gostaríamos de destacar algumas características da matemática de Mydorge e sua relação intelectual com Descartes. Claude Mydorge (1585-1647), embora seja raramente mencionado nas biografias de Descartes e nos manuais de história da matemática, é não só uma grande influência para Descartes mas um dos maiores matemáticos da época.

${ }^{128}$ Cf. MANDERS, 2008, p. 72. 
Adrien Baillet, o primeiro biógrafo de Descartes, o descreve como "o mais importante daqueles novos amigos" e que "M. Descartes encontrou nesse novo amigo um não-sei-quê, que lhe renovava extremamente, seja pelo humor, seja pelo caráter de espírito". ${ }^{129}$ Noutra passagem, diz que "M. Descartes não via, depois do Padre Mersenne, nenhum dos seus amigos com mais assiduidade que M. Mydorge", a ponto de ser chamado por Descartes de "prudente e fiel amigo". 130 Além do afeto que provocara em Descartes, Mydorge também, como é noticiado por Baillet, "sucedeu Viète na reputação de ser o primeiro Matemático da França", sendo, nas palavras de Maièru, aquele que reuniu o melhor da tradição sobre as cônicas. ${ }^{131}$

Para além da relação de amizade entre Descartes e Mydorge, deve-se lançar luz sobre a influência que exerceu Mydorge sobre Descartes no que diz respeito a algumas características da sua geometria e seu estilo de prova. Em seu primeiro escrito sobre as cônicas, além das provas, Mydorge estabelece comentários em várias partes do texto, que ele tece sob o título de Monitum (literalmente: advertência ou aviso).

Em primeiro lugar, Mydorge, que se esforça no aprimoramento, não por meio de reconstruções mais "rigorosas", mas encurtando passos e pensando em atalhos demonstrativos para demonstrações de Apolônio acerca das cônicas. Logo no início de seu tratado, a sua posição em relação aos antigos atrai a atenção. Pondo-os em seu lugar, sem os mal ajuizar ou abjurar do legado da tradição clássica, afirma que em sua obra não haverá espaço para citações dos trabalhos dos matemáticos antigos, como Apolônio. Quanto às demonstrações desse último, simplifica-las é seu objetivo. Essa ambição parece se encaixar perfeitamente com o que se foi falado sobre a abreviação na metodologia cartesiana. Maierù, por outro lado, enfatiza a atitude de delimitação ou diferenciação entre a herança dos antigos e o trabalho dos matemáticos modernos. Eis, pois, o que diz Mydorge:

Contudo, nem um nem outro ocorrerá em nenhum lugar, isto é: a indicação ou a menção de autores. Uma norma da obra será seguida: a razão geométrica dos elementos de Euclides, com a qual se alguém estiver minimamente habituado, não sentirá dificuldade alguma, e sem dificuldade percorrerá facilmente todo o edifício, com seus próprios

\footnotetext{
${ }^{129}$ Cf. BAILLET, 1691, p. 36-37.

${ }^{130}$ Cf. BAILLET, 1691, p. 149-150.

${ }^{131}$ Cf. MAIÈRU, 2009, p. 106.
} 
pés. Mas, certamente, não depende das secções cônicas de Apolônio, e ademais tem seus próprios elementos, que revelam a matéria de toda a obra no primeiro livro. Também essa não é mudada e aceita pela mesma natureza do assunto exposto já observado mais profundamente: de tal modo que deverão parecer de longe mais simples que os elementos de Apolônio: e uma vez que contêm as fontes de onde o mesmo Apolônio, por meio de um artifício oculto, deduziu riachos precípuos e capitais. (GRIFO NOSSO) ${ }^{132}$

Descartes, semelhantemente, não menciona nenhum matemático, e nem mesmo quando se serve de alguma demonstração de outrem. Essa ausência de alusões é, de fato, consciente e tem uma explicação. ${ }^{133}$

Em segundo lugar, e que não é senão uma forma de seguir à risca o intento de simplificação, citada no parágrafo acima, Mydorge não acompanha Apolônio a respeito das demonstrações indiretas (ou por redução ao absurdo). Mydorge as recusa por completo. Vejamos o que diz Mydorge: "Por um lado, todas as coisas são, no mesmo livro primeiro e principal, demonstradas diretamente, e que são pelo mesmo Apolônio e por muitos demonstradas indiretamente e redução ao absurdo." 134

Mancosu chama a atenção para a discussão acerca do status da demonstração por redução ao absurdo, suscitada pelos matemáticos do século XVII, sobretudo a partir da "questão da certeza das matemáticas". ${ }^{135}$ Assim, o esforço de se distanciar desse tipo de procedimento, que há tanto em Descartes como Mydorge, não é uma particularidade desses dois matemáticos, mas algo lançado à atmosfera da época. Contudo, todas as considerações, tecidas por Descartes, à redução, que podem ser encontradas somente na correspondência, estão relacionadas com sua crítica ao método demonstração de Fermat. ${ }^{136}$ Numa

\footnotetext{
132 No original latino: Quanquam \& neuter ullibi ut auctor designatus aut invocatus occurret. Norma operi una erit geometrica ratio Euclideis elementis contenta, cui si quis vel tantillum assueverit nullum inibi sentire obicem, \& inoffenso pede totum facile percurret aedificium. At certe ab Apollonianis non pendet elementis conicis, nam \& própria habet elementa quae operis libro materiam supediaverunt. Atque ipsa quidem non aliunde mutuata \& accepta quam ab ipsa rei propositae penitius introspectae natura: eiusmodi etiam ut elementis \& Apollonianis longe videri debeant simpliciora: quandoquidem \& fontes continent unde ipse Apollonius oculto artificio praecipus \& captales deduxit rivulos. Cf. MYDORGE, 1631, n. p.

${ }^{133}$ Carta de Descartes a Elisabeth de novembro de 1643 (AT, IV, 47).

${ }^{134}$ No original: Hinc omnia à nobis in eodem primo \& principal libro directè sunt demonstrata, quae ab ipso Apollonio plerumque indirecte, \& ab absurdi consequentia sunt probata [...]. Cf.

MYDORGE, 1631, n. p.

${ }^{135}$ Cf. MANCOSU, 1996, p. 24-33.

136 Todas os comentários de Descartes a respeito das demonstrações por redução ao absurdo podem ser encontradas nas seguintes passagens: Carta a Mersenne de janeiro de 1638 (AT, I,
} 
dessas passagens, Descartes diz que julgava a redução a "menos estimada" e "menos engenhosa" maneira de demonstrar. Além disso, dela não se utiliza n'A Geometria. Mydorge pensa de modo parecido, mas por uma razão diferente: crê numa simplicidade ou facilidade das demonstrações diretas. Não há, com efeito, nenhuma evidência que leve a acreditar em algum tipo de influência acerca da crítica coincidente no trato com as demonstrações indiretas. Porém, é possível dizer que, apesar de razões distintas, convergiam à mesma posição.

Em terceiro lugar, Mydogre introduz, no primeiro livro dos Prodromi catoptricorum et dioptricorum [...] (1631), depois das primeiras 19 definições, mais duas novas, que ele chama de "segundas definições", e que introduzem triângulos subcontrários e seções subcontrárias.

I. Diz-se posição subcontrária quando dois triângulos semelhantes postos em um ângulo vertical comum não têm bases paralelas. E por essa razão os mesmos triângulos são denominados posições subcontrárias, ou também bases postas de maneira subcontrária.

II. Diz-se secção cônica subcontrária: quando o cone é seccionado por dois planos no mesmo pelo eixo do triângulo reto, e por isso mesmo dois triângulos semelhantes, mas postos de maneira subcontrária; ou quando o cone já seccionado através do eixo, pelo plano reto, na base, e é seccionado inversamente pelo plano reto no triângulo através do eixo, e pelo mesmo ao vértice com o triângulo cortado, mas posto de maneira subcontrária. ${ }^{137}$

Essas duas noções dependem da semelhança de triângulos e são abundantemente utilizadas ao longo de suas demonstrações.

Outras tantas considerações elaborou Mydorge. Contudo, não convém aqui as retomar, uma vez que o foco são as semelhanças e de que modo sua obra, ou mesmo seu estilo demonstrativo, pode ter influenciado Descartes. Algumas das posições de Mydorge são, por exemplo, o tratamento não abstrato dos objetos geométricos, pois, enquanto estudioso da óptica, tenta uma aproximação entre as cônicas e os problemas de física, e, no que se refere aos princípios, ele considera

490), Carta a Mersenne de 29 de junho de 1638 (AT, II, 177) e Carta a Mersenne de 27 de julho de 1638 (AT, II, 274).

${ }^{137}$ No original: I.Subcontrariam positionem dicimus, quando bina triangula similia ad communem verticalem angulum posita bases habent non parallelas. Ideoque \& ipsa triangula dicentur subcontrarie posita. Atque etiam bases subcontrarie invicem positae. II.Subcontrariam coni sectionem dicimus, sive conus secetur duobus planis ad idem per axem triangulum rectis, \& ab ipso verticem abscidentibus bina triangula similia, sed subcontrarie posita. Sive conus per axem jam sectus plano ad basim recto, rursus secetur plano ad triangulum per axem recto, \& ab ipso ad verticem abscindente triangulum símile, sed subcontrarie positum. Cf. MYDORGE, 1660, p. 5. 
que definições podem ser tratadas como problemas ou teoremas, estando esse critério subordinado à perspectiva do leitor.

Além das evidências históricas que encontramos nas cartas, parece convincente que a demonstração seja atribuída a Mydorge. Se observarmos o texto de matemática de Mydorge, ficamos quase convencidos de sua proximidade com o estilo demonstrativo da resolução do problema das duas médias proporcionais. Deve-se acrescentar também que, apesar de seu estilo axiomático, ao que Descartes era em certo sentido avesso, há algo que coincidem: a preferência em exibir relações proporcionais e triângulos semelhantes, que são na linguagem de Manders aspectos exatos do diagrama, e que já foram exemplificados acima na construção de duas médias proporcionais.

\section{9}

\section{O "segredo universal": a demonstração de Descartes}

Segundo a estimativa de Costabel, no dia 8 outubro de 1628, numa visita a Beeckman, além da demonstração de Mydorge, Descartes apresenta-lhe, um método geral de construção, de sua autoria, para raízes de equações do terceiro e quarto graus a partir da intersecção de uma parábola e de um círculo. Essa demonstração será publicada por Beeckman três meses depois no seu Journal, que a descreve, entusiasmado, do seguinte modo: "segredo universal de todas as difíceis equações de terceira ou quarta dimensão" (secretum universale ad aequationes omnes tertiâ vel quartâ dimensione involutas). ${ }^{138}$

Ao que parece, Beeckman foi o único dos seus amigos a quem Descartes mostrou a demonstração. Segundo Bos, é improvável que Descartes tenha mostrado a regra geral de construção aos matemáticos de Paris (Mydorge, Hardy, Mersenne e Roberval). ${ }^{139}$ Com efeito, a demonstração só seria apresentada ao grande público na publicação d'A Geometria como um modelo de construção para equações do terceiro e quarto graus. Um detalhe curioso, e que se nota de imediato, é que a demonstração, publicada por Beeckman, não é descrita numa

${ }^{138}$ Cf. COSTABEL, 1982, p. 51 e Cf. Descartes e Beeckman (AT, X, 344).

${ }^{139}$ Cf. BOS, 2001, p. 256 e 258. 
escrita algébrica. Toda a apresentação da prova é feita com palavras, ao invés de equações. Ainda que se possa, reconstruí-la facilmente com o cálculo algébrico.

Esse procedimento geral pode ser aplicado para a resolução do problema das duas médias proporcionais; o resultado da construção é o mesmo que o apresentado em 1625 aos matemáticos de Paris. É por essa estreita semelhança e relação entre as duas demonstrações que Bos acredita na possibilidade de as construções (geral e particular) do problema das duas médias proporcionais terem sido encontradas, aproximadamente, no mesmo período, isto é, por volta de 1625. 140 A tese de Bos apoia-se, sobretudo, no texto de Daniel Lipstorp, Specimen philosophiae Cartesianae, de 1653. Esse livro descreve o encontro, em torno do início da década de 1620, entre o matemático alemão Johann Faulhaber e Descartes, em Ulm. E sugere ademais que Descartes já estivesse na posse da construção geral.

Quanto ao modo como Descartes encontrou a prova, não podemos saber simplesmente pelas provas de Mydorge e Roberval, uma vez que elas são sintéticas. Bos, então, sugere duas possibilidades. Primeiramente, Descartes poderia ter alcançado a construção geral através do método dos coeficientes indeterminados, que é apresentado no comentário de Frans van Schooten. Acerca do método dos coeficientes indeterminados, Rabouin faz a seguinte observação:

O método dos coeficientes indeterminados era conhecido e usado
pelos algebristas cossistas, mas num contexto aritmético. Ao aplica-lo
num contexto geométrico no qual curvas são representadas e
manipuladas por meio de suas equações, Descartes teria dado seu
primeiro passo em direção àquilo que seria o cerne da nova técnica da
Géométrie. ${ }^{141}$
Em segundo lugar, a construção poderia ter sido alcançada a partir de sucessivas generalizações do problema de duas médias proporcionais. ${ }^{142}$

Em relação à tentativa de articular a demonstração de 1629 com o texto de 1637, Rabouin diz que muitos comentadores simplesmente substituem a construção da década de 1620 pelas construções da terceira parte d'A Geometria reservada à solução de problemas sólidos. Todavia, como mostra Rabouin, a

140 Cf. BOS, 2001, p. 257. A mesma estimativa é estabelecida por Serfati e Rabouin. Cf. SERFATI, 2002, p. 74 e Cf. RABOUIN, 2010, p. 455-456.

${ }^{141}$ Cf. RABOUIN, 2010, p. 456.

${ }^{142}$ Cf. BOS, 2001, p. 258. 
interpretação de Serfati e que é simplesmente sugerida por Bos como uma possibilidade, isto é: de que Descartes já estaria praticando análise algébrica, é equivocada. Esse argumento se baseia numa petição de princípio, segundo Rabouin: se Descartes fazia análise algébrica já nesse período, então essas reconstruções algébrica podem ser corretas; e se as reconstruções são corretas, Descartes já fazia análise algébrica. ${ }^{143}$

Outro argumento, levantado por Rabouin, consiste na constatação de que Descartes ainda naquele período usava equações cóssicas, e não é fácil, através de símbolos cossistas, expressar e manipular a equação geral de um círculo. Uma pista que sustenta o argumento de Rabouin é que, apesar de a prova ser apresentada sem o suporte de uma escrita simbólica, a descrição dos coeficientes da equação é feita por expressões como "o número dos quadrados", "número das raízes" e "número absoluto" - que não são senão próprias do jargão cossista, especialmente de Clavius. Rabouin, ademais, rejeita a essa reconstrução porque ela pressupõe que Descartes estaria naquele tempo estudando curvas através de equações; e, na verdade, mesmo em obras posteriores, Descartes não manipula equações de círculos, preferindo o emprego do teorema de Pitágoras. Assim, conforme a visão de Rabouin, não se deve projetar o estudo das curvas no contexto dessa demonstração, mas, sim, o da teoria das equações e, de modo mais significativo, de suas respectivas construções. ${ }^{144}$

Vejamos a construção (fornecida por Descartes, mas que foi alterada por posta numa linguagem atualizada por Bos) ${ }^{145}$ para equações de terceiro e quarto graus $\left(z^{4}= \pm a z^{2} \pm b z \pm c\right)$ :

\footnotetext{
${ }^{143}$ Cf. RABOUIN, 2010, 456 e Cf. SERFATI, 2002, p. 101-102.

${ }^{144}$ Cf. RABOUIN, 2010, p. 456-457.

${ }^{145}$ Essa prova foi retirada de Bos. Cf. BOS, 2001, p; 256-257. A tradução direta da prova de Descartes segue no apêndice do presente trabalho.
} 


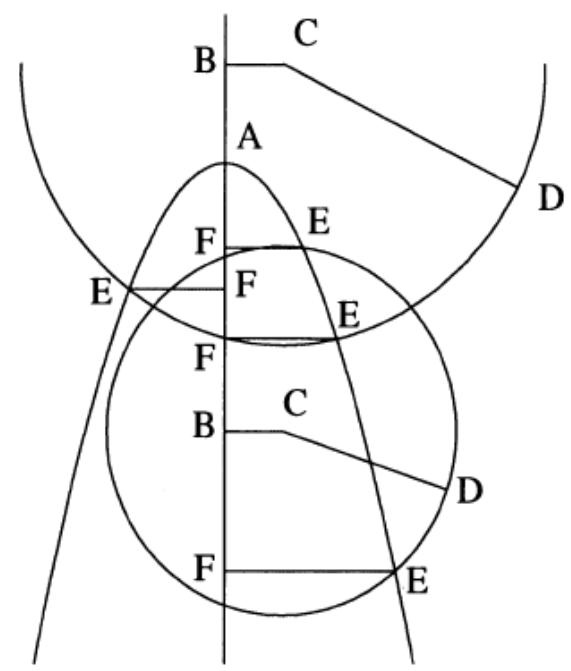

Figura 7 BOS (2001, p. 256)

Construção:

I) Traçar a parábola com eixo vertical, vértice $A$ como o ponto máximo, latus rectum 1. II) Se o sinal de $p$ é + , então toma-se $\mathrm{AB}=\frac{1+p}{2}$ de $\mathrm{A}$ ao longo de todo o eixo abaixo; se o sinal é - e $p<1$, então toma-se $A B=\frac{1-p}{2}$ de $\mathrm{A}$ ao longo de todo o eixo abaixo; se o sinal é - e $p>1$, então toma-se $A B=\frac{1-p}{2}$ de $\mathrm{A}$ ao longo de todo o eixo acima; finalmente, se o sinal é - e $p=1$, então toma-se $B=$ $A$. III) Considere $B C=\frac{q}{2}$ perpendicular ao eixo tanto à direita quanto à esquerda (a escolha é a da esquerda, conforme o geômetra executa na construção). IV) Se o sinal de $r$ é + , então considere o segmento de reta $C D=\sqrt{C A^{2}-r}$. V) Construa o círculo com centro em $C$ e raio $C D$; ele intersecta a parábola nos ponto $E$; construa perpendiculares EF ao eixo. VI) Se o sinal de $q$ é -, então os segmentos $E F$ nos quais $E C$ intersecta o eixo representam as raízes positivas; as outras, as negativas; se o sinal de $q$ é + , então os seguimentos $E F$ nos quais $E$ é no mesmo lado do eixo que $C$ representam as raízes positivas; e as outras, as negativas.

Bos sugere o seguinte método de obtenção da construção ${ }^{146}$ (que é condenado por Rabouin, como pode ser lido acima):

A parábola tem a seguinte equação: $y=x^{2}$. Deixe o centro $\mathrm{C}$ de o círculo ter as coordenadas $(a, b)$ e deixe c ser o raio do círculo; sua equação é a seguinte:

${ }^{146}$ Essa prova segue a reconstrução de Bos. Cf. BOS, 2001, p. 257. 
$(x-a)^{2}+(y-b)^{2}=c^{2}$, e o $x$ coordena os pontos da intersecção que satisfaz a equação $x^{4}=(2 b-1) x^{2}+(2 a) x+\left(c^{2}-a^{2}-b^{2}\right)$. Assim, se se escolhe $a, b$ e $c$ tal que $2 b-1= \pm p, 2 a= \pm q$ e $c^{2}= \pm r+a^{2}+b^{2}$, os pontos da intersecção do círculo e da parábola fornecerão as raízes. ${ }^{147}$

\subsection{0}

\section{Duas médias proporcionais n'A Geometria}

A primeira coisa que se observa da demonstração de duas médias proporcionais apresentada n'A Geometria, de Descartes, é o que percebeu Sasaki: "Descartes reescreverá a solução de Mydorge numa fórmula algébrica simples e a incorporará no livro III da Geometria, de 1637, sob o subtítulo à margem de "A invenção de duas médias proporcionais". ${ }^{148}$ A solução a que se refere Sasaki é a etapa que Mydorge chama de síntese. Por outro lado, observa-se também que a construção é a mesma de Mydorge, mas sem as construção auxiliares e com a parábola arrastada para lado direito.

A demonstração é breve e, a partir de uma rápida manipulação simbólica da relação de duas médias proporcionais $(a: z=z: y=y: q)$, obtém-se $a y=z^{2}$, $z q=y^{2}$ e $a q=z y$. Na equação $a q=z y$, subistituindo-se $y$ por $\frac{z^{2}}{a}$, chega-se à equação $z^{3}=a^{2} q$. O mais interessante, entretanto, não é a demonstração em si, mas reparar que o papel menor figurado pelo problema das duas médias proporcionais tem a ver com o fato de ela ser apenas um caso particular da construção de problemas sólidos. ${ }^{149}$ Aquela breve demonstração escondia, contudo, uma longa história de discussões anteriores com diversos matemáticos.

\footnotetext{
${ }^{147}$ A intuição da prova consiste em tomar a equação da circunferência, $x^{2}-2 a x+a^{2}+y^{2}-$ $2 y b+b^{2}=c^{2}$, e substituir o $y$ por $x^{2}$. ${ }^{148}$ Cf. SASAKI, 2003, p. 172 e A Geometria (AT, VI, 469).

149 É por essa razão que Descartes inicia essa demonstração do seguinte modo: Si on veut donc suivant cete reigle trouver deux moyennes proportionnelles [...].
} 


\section{Conclusão}

Como foi visto no primeiro capítulo, o debate metodológico no campo das matemáticas suscitado pela "questão da certeza das matemáticas" influenciou uma miríade de matemáticos do século XVI e XVII. Alguns aderiram à querela tomando partido ora em nome da cientificidade das matemáticas, ora desafiando as demonstrações matemáticas, negando-lhe estes o status de ciência. Há, contudo, uma semelhança entre os dois grupos de matemáticos, a saber: ambos se serviram do aparato categorial aristotélico. Assim, alguns desses matemáticos absorveram os moldes metodológicos da ciência demonstrativa aristotélica para fazê-los convergir às demonstrações da matemática (não só as da matemática clássica como os novos problemas matemáticos que se deparavam). Já outros matemáticos envolvidos na Quaestio emprenharam-se em mostrar uma falha nas provas geométricas, sinalizando que as matemáticas (especialmente a geometria clássica) não obedeciam aos seus critérios de rigor científico.

Descartes, todavia, não se encaixava em nenhum desses dois grupos. Seu projeto metodológico começa, antes de tudo, pela rejeição ao formalismo silogístico. E por esse motivo, não está preso ao aparato categorial da ciência demonstrativa aristotélica. Assim, ao invés de se dedicar a reconstrução de provas euclidianas, Descartes prega um novo modelo metodológico fundado no conceito de intuição, que é acompanhado por outro, que é a dedução. Intuição e dedução não se excluem, antes se complementam e se articulam conjuntamente.

Quanto à intuição, abordada no segundo capítulo, ele explica como se dá nosso acesso aos primeiros princípios (inclusive os princípios da geometria) e algumas operações da aritmética. Ademais, um dos elementos do seu modelo fundado na intuição é o de conferir a esse ato intelectivo imediato a capacidade de também acessar deduções, que ele exemplifica com os diversos teoremas da geometria euclidiana. O seu modelo de dedução diverge daquela que é elaborada pela lógica das escolas. Afinal, embora aceite boa parte das regras simples da 
silogística aristotélica, como é admitido pelo próprio autor, Descartes rejeita as outras diversos "preceitos dos dialéticos".

A fim de encontrar o funcionamento prático da intuição, buscamos n'A Geomteria algum tipo de esclarecimento. Todavia, o que acontece inicialmente é que a intuição no texto d'A Geometria parece operar com ligeiras diferenças em relação ao que foi apresentado pelas Regras, ainda que não necessariamente contraditórias. Assim, descobrimos que a intuição opera discretamente n'A Geometria sob outra perspectiva. A intuição parece adquirir na matemática de Descartes uma função fundacional, que permite distinguir quais são os objetos geométricos e quais não o são. Ao fazer isso, Descartes observa que se conhece com a mesma clareza e distinção os objetos mais básicos da geometria euclidiana (encarnados nos postulados I.1 e I.3, isto é, aqueles descrevem a reta e o círculo). Mas, vai além. Há outros objetos como secções cônicas (parábola, hipérbole e elipse) e outras figuras geométricas ainda mais complexas que podem ser conhecidas intuitivamente com o mesmo grau de clareza e distinção que os objetos mais simples.

Além do mais, a intuição não joga um papel direto nas demonstrações, mas pode auxiliar na compreensão da prova. Por essa razão, além da função fundacional, a intuição em sua dimensão prática parece abarcar outra, que é uma função heurística. Esse papel da intuição, contudo, prefigura já nas Regras, onde Descartes defende que a instanciação do objeto geométrico aumenta a nossa atenção sobre o objeto em questão e, consequentemente, a distinção do objeto matemático.

Finalmente, a fim de investigar in loco a matemática de Descartes, selecionamos o problema das duas médias proporcionais. A reconstrução histórica desse problema nos permitiu lançar luz sobre uma questão ainda pouco estudada, e que, todavia, vem ganhando destaque entre os especialistas da história e filosofia das matemáticas. Devemos mencionar ainda que essa análise nos permitiu uma comparação entre um modelo de demonstração cartesiana e outro de Roberval. Este último encarna o grupo de matemáticos que tentava conciliar, ao mesmo tempo, a metodologia aristotélica e a prática matemática euclidiana. 
Há uma grande diferença entre os dois estilos demonstrativos, o de Descartes e o de Roberval. Diante do mesmo problema matemático, ambos apresentam respostas diferentes. Na demonstração de Roberval, encontramos alguns elementos marcantes: a utilização reiterada de princípios e proposições euclidianas, buscando uma maior conformidade com a prática matemática de Euclides. Do outro lado, temos a demonstração de Descartes, que apela a proporção entre triângulos. Contudo, além dessas diferenças gerais, analisamos outros detalhes da prova. A demonstração de Roberval apresenta outras características: seu comprimento, a invariabilidade do diagrama e a multiplicação de casos. Esses três elementos se relacionam intimamente, e a causa dessas três características foram observadas por Manders, em seus últimos artigos sobre a visualização do diagrama. O especialista distingue entre aspectos do diagrama que são exatos e outros que são co-exatos, e são ilustrados respectivamente pela abordagem matemática cartesiana e euclidiana. $\mathrm{O}$ uso feito por Roberval do livro II d'Os Elementos, de Euclides, na resolução do problema das duas médias proporcionais acarreta nas consequências, já apontadas por Manders, de multiplicação de casos e invariabilidade do diagrama. Dessas duas consequências resulta ainda o comprimento da prova.

Assim, a prática matemática de Descartes, exemplificada pela análise da demonstração das duas médias proporcionais confirma as teses desenvolvidas por Manders. E, não só isso, o próprio Descartes parece ter de algum modo consciência das suas escolhas demonstrativas. Pois, ele mesmo vê uma diferença entre as suas provas e as provas dos matemáticos que procuram "a construção e a demonstração pelas demonstrações de Euclides". Essa escolha, repudiada por Descartes, tem como consequência "multiplicações supérfluas", são mais longas (em oposição aos seus "caminhos curtos") e não são capazes de formular "regras gerais". ${ }^{150}$ De fato, esses três elementos, encontrados na demonstração de Roberval de duas médias proporcionais, são a antítese do que busca Descartes em sua prática matemática. Dessa maneira, a análise do problema das duas médias proporcionais evidencia o procedimento matemático de Descartes.

${ }^{150}$ Carta de Descartes a Elisabeth de novembro de 1643 (AT, IV, 47). 


\section{Referências bibliográficas}

Fontes primárias:

ARISTOTE. Oeuvres complètes. Tradução em francês: Pierre Pelegrin. Paris: Flammarion, 2014.

CLAVIUS, Christophorus. Euclidis elementorum libri XV: Accessit XVI. de solidorum regularium cuiuslibet intra quodlibet comparatione: omnes perspicuis demonstrationibus, accuratisque scholiis illustrati, ac multarum rerum accessione locupletati... Roma: 1603.

CONIMBRICENSIS. Commentarii Collegi Conimbricensis Societatis Iesu: In universam Aristotelis Logicam Tomus Alter, Hamburg: Bibliopolo Frobeniano, 1604.

CONIMBRICENSIS. Commentarii Collegi Conimbricensis Societatis Iesu: In universam Aristotelis Logicam Tomus Alter, Veneza: J. Vincentium et R. Amadinum, 1604.

DESCARTES, René. Oeuvres De Descartes, 11 vols., editada por Charles Adam e Paul Tannery, Paris: Librairie Philosophique J. Vrin, 1983.

HARDY, Claude. Examen de la duplication du cube, et quadrature du cercle. Paris: 1630.

MERSENNE, Marin de. La vérité des sciences contre les septiques ou Pyrrhoniens. Paris: 1625.

MERSENNE, Marin de. Harmonicorum Libri, in quibus agitur desonorum natura, causis et effectibus. Paris: 1636.

MERSENNE, Marin de. Harmonie universelle contenant la théorie et la pratique de la musique. Paris: 1637.

MYDORGE, Claude. Prodromi catoptricorum et dioptricorum sive Conicorum operis ad abdita radii reflexi et refracti mysteria praevii et facem praeferentis libri primus et secundus. Paris: 1631. 
MYDORGE, Claude. Prodromi Prodromi catoptricorum et dioptricorum sive Conicorum operis ad ábdita radii reflexi et refracti mysteria praevii et facem praeferentis. Libri quatuor priores. Paris: 1660.

PEREYRA, Benito. De Communibus rerum naturalium principijs \& affectionibus.... Roma: 1585.

ROBERVAL, G. P. Éléments de géométrie de G. P. de Roberval. Paris: Librairie Philosophique J. Vrin, 1996.

YVON, Paul. Quadrature du cercle, ou Moyen de trouver un quarré égal au cercle donné et au contraire un cercle égal au quarré proposé. Ensemble, Le double du cube ; inventée et trouvée par Paul Yvon, avec les Éclaircissemens paropérations numérales et la parfaicte proportion du diamètre à la circonférence. La Rochelle: 1619.

Fontes secundárias:

BOS, H. J. M. Redefinig Geometrical Exactness - Descartes' Transformation of the Early Modern Concept of Construction. New York: Springer Verlag, 2001.

La structure de la Géométrie de Descartes. In: Revue d'histoire des sciences, vol. 51, n²-3, 1998. Pour Descartes Mathématiques et physique cartésiennes. p. 291-318.

LASSAlle CASANAVE, Abel. Por resolução de problemas. Em torno da filosofia kantiana da matemática. A ser publicado.

COSTABEL, Pierre. Démarches originales de Descartes Savant. Paris: Librairie Philosophique J. Vrin, 1982.

CRIPPA, Davide. Impossibility results: from geometry to analysis. A study in early modern conceptions of impossibility. Tese (Doutorado em Filosofia). Universidade Paris Diderot (Paris VII), 2014.

DE RISI, Vincenzo. The development of Euclidean axiomatics. Archive for History of Exact Sciences, 70:591-676, 2016.

CLARKE, Desmond. Descartes philosophy of science.Manchester: Manchester University Press, 1982.

EUCLIDES. Os Elementos. Tradução: Irineu Bicudo. São Paulo: Unesp, 2009. 
VAN DER WAERDEN, Bartel. Science awakening. Dordrecht: Kluwer Academic Publishers, 1975.

GAUKROGER, Stephen. Cartesian Logic. An essay on Descartes's conception of inference. Oxford: Clarendon Press, 1989.

GILSON, Étienne. Discours de la Méthode. Texte et Commentaire. Paris: Vrin, 1987.

JULLIEN, Vincent. Descartes La Géométrie de 1637. Paris: Presses Universitaires de France, 1997.

JULLIEN, Vincent. Éléments de géométrie de G. P. de Roberval. Paris. Librairie Philosophique J. Vrin, 1996.

JULLIEN, Vincent. Philosophie naturelle et géométrie au XVIIe siècle. Paris: Honoré Champion, 2006.

LÜTZEN, Jesper. The Algebra of Geometric Impossibility: Descartes and Montucla on the Impossibility of the Duplication of the Cube and the Trisection of the Angle. In: Centaurus, 52:4-37, 2010.

MAIERÙ, Luigi. Le sezioni coniche nel Seicento. Soveria Mannelli: Rubbettino Editore, 2009.

MANCOSU, Paolo. Philosophy of mathematics and mathematical practice in the seventeenth century. New York: Oxford University Press, 1996.

MANDERS, Kenneth. Diagram-Based Geometric Practice. In: MANCOSU, Paolo. Philosophy of Mathematical Practice. Oxford: Clarendon Press, 2008.

MANDERS, Kenneth. Euclides or Descartes? Representation or Resposiveness. A ser publicado.

MARION, Jean-Luc. Sur l'ontologie grise de Descartes: science cartésienne et savoir aristotélicien dans les Regulae. Paris. Librairie philosophique J. Vrin, 2000 .

MEHL, Edouard. Descartes critique de la logique pure. In: Les Études philosophiques, p. 485-500, 2005.

MILHAUD, Gaston. Descartes Savant. Paris: Librairie Félix Alcan, 1921. 
PANZA, Marco. Rethinking Geometrical Exactness. Historia Mathematica, 38:42-95, 2011.

RABOUIN, David. What Descartes knew of mathematics in 1628. Historia Mathematica, 37:428-459, 2010.

RABOUIN, David. Les mathématiques de Descartes avant la Géométrie. In: THIBAUT, Gress. Cheminer avec Descartes. Concevoir, raisonner,comprendre, admirer et sentir. Paris: Classiques Garnier, p. 293-311, 2018.

ROQUE, Tatiana. História da matemática. Rio de Janeiro: Zahar, 2012.

SAITO, Ken. Book II of Euclid's Elements in the Light of the Theory of Conic Sections. In: Historia Scientiarum. 28:31-60. 1985.

SASAKI, Chikara. Descartes' Mathematical Thought. Holanda: Kluwer Academic, 2003.

SEPPER, Dennis. Descartes's Imagination: Proportion, Images, and the Activity of Thinking. Berkeley: University of California Press, 1996. SERFATI, Michel. De la méthode: recherches en histoire et philosophie des mathématiques. Besançon: Presses universitaires franc-comtoises, 2002.

SHEA, William. La magia de los números y el movimiento - La carrera científica de Descartes. Madrid: Alianza Universidad, 1993. 
Anexo

\section{1}

Costrução de Mydorge para duas médias proporcionais (Journal de Beeckman) ${ }^{151}$

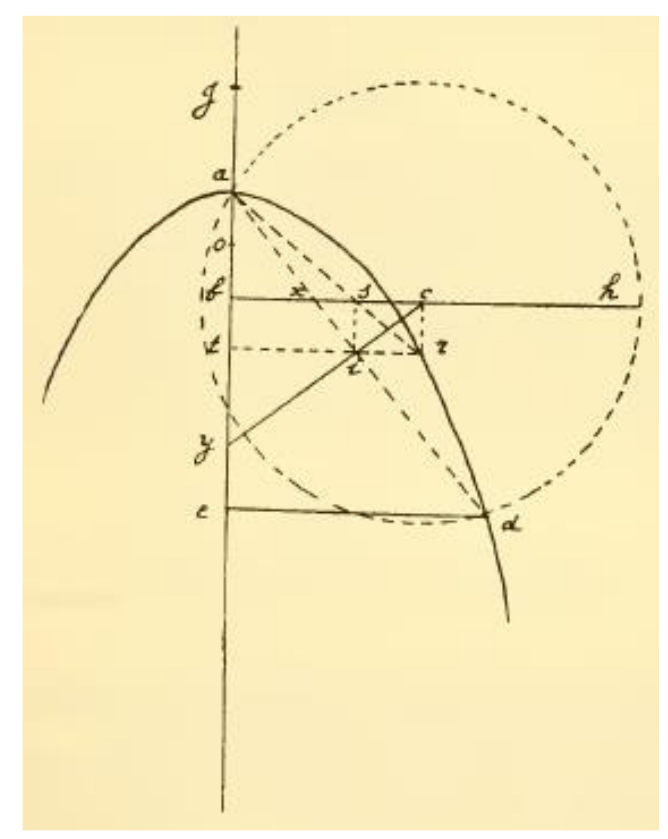

Figure 8 (AT, X, 343)

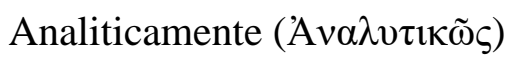

Seja já feito; e sejam duas médias na figura anexa [adscripta], enquanto et é a menor, ea é a maior. E uma vez que ed e ea são médias numa proporção contínua, $g b$ estará para $e a$, e assim ed estará para ea e $e a$ para $b h$; e o quadrado contido pela primeira é igual ao retângulo contido pela segunda $[g b]$ e terceira $[e a]$. Contudo, se se estabelece de como segunda e prolongada perpendicular aos ângulos retos da terceira $a e$, será ae o eixo da parábola cujo vértice $a$ e o latus rectum será o mesmo primeiro $g b$. Seja então descrita na parábola.

Uma vez que $b g$ está para de assim como de está para ea e ea está para $b h$, extraídas todas as raízes quadradas (prolongadas por $a d$, certamente é bissecada em $i, \& t i$ prolongada a $r n$, afim de que seja igual \& paralela à metade de $b h$ )

${ }^{151}$ Journal de Beeckman (AT, X, 342-344). 
estará assim $a b$ para $b s$, isto é: $t i$, assim $t i$ estará para $t a, \&$ assim $t a$ está para $t r$, isto é: $b c$. Desse modo, são ambos, ati, atr, triângulos similares \& equiângulos, \& o ângulo tai igual ao ângulo atr. Assim, at está para tr, assim como si está para $i r$, isto é: is está para $s c$ (com efeito, prolongadas $i s, c r$ em relação ao eixo paralelo) $\& y t$ está para $t i$. Desse modo, são semelhantes atr, isr, yti, ita triângulos e equiângulos, e por essa razão os ângulos art, ics, yit, tai são iguais entre si. E então devido à similitude é assim $a t$ está para $t i, t i$ está para ty; com efeito, aiy é um ângulo no semicírculo, e é também reto. Além disso, o que vem em seguida, aic, é reto. Assim, devido à igualdade de $a i, i d, \& i c$ comum, serão os triângulos aic, dic semelhantes \& iguais entre si, e do mesmo modo $a c$ igual a $c d$, e ambos são raio do círculo cujo centro é $c$.

\section{Sinteticamente $(\Sigma v v \theta \varepsilon \tau \iota \kappa \tilde{\omega} \varsigma)$}

Seja então construído. Sobre a reta ge ilimitada, $a b$ será cortada igual à metade menor do extremo $g b \&$ à direita de $a b, b h$ é construído igual ao maior do extremo, que é bissectado em $c$; com centro em $c$ e distância $c a$, a circunferência do círculo é descrita. Precisamente, $a b$ é bissectada em $o$, com foco $o$ e vértice em $a$, a parábola $a d$ é descrita cortando a circunferência no ponto $d$, à qual é prolongada perpendicularmente \& à direita a reta $d e$. Digo que o mesmo de é a menor das médias investigadas \& ae maior. Dessa maneira, acontecerá que $g b$ está para $d e$, assim como de está para ae e $a e$ está para $b h$. 


\section{2}

Método geral de Descartes (Journal de Beeckman) ${ }^{152}$

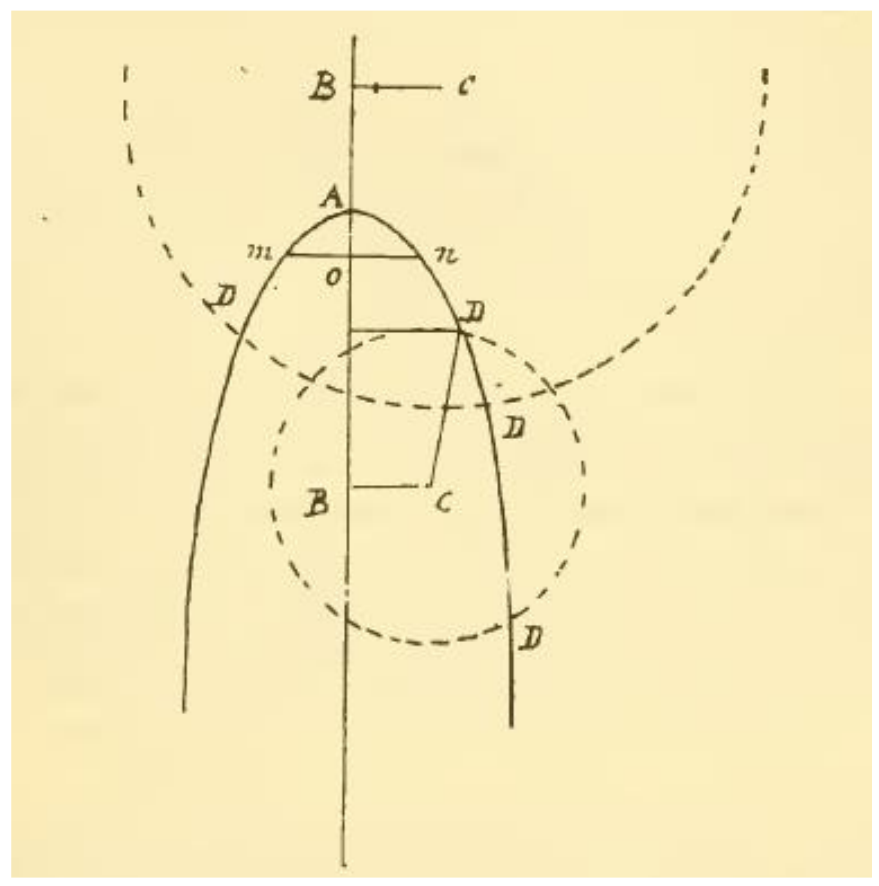

Figure 9 (AT, X, 343)

Construir todos os problemas sólidos com auxílio de uma parábola através de um método geral. Que D. des Chartes noutro lugar chama de segredo universal de todas as difíceis equações de terceira ou quarta dimensão a serem expostas [ou formadas] por linhas geométricas. Que descrevo de outros [ou seus] escritos ad verbum: Primeiramente, que uma equação tenha sido preparada de tal modo que fique:

$$
z^{4}= \pm a z^{2} \pm b z \pm c^{153}
$$

Em seguida é descrita a parábola cujo vértice $\mathrm{A}$, foco $\mathrm{O}$, de tal modo que o latus rectum $\mathrm{mOn}$, que passa pelo foco seja uma unidade; e seja prolongado o diâmetro AO em ambos os lados ao infinito, \& naquela o ponto B é assumido, dentro e fora da parábola, do qual a linha $\mathrm{BC}$; \& do centro $\mathrm{C}$ o círculo DD é descrito, que intersectará a circunferência da parábola em dois, ou em um ou em três, para ser

\footnotetext{
152 Journal de Beeckman (AT, X, 344-346).

${ }^{153}$ No original: biquadratum aequale + vel - certo numero quadratorum, + vel -certo numero radicum, \& + vel - certo numero absoluto.
} 
atravessado naturalmente pelo vértice, ou com quatro pontos, dos quais as linhas perpendicularmente descendentes sobre o diâmetro AO serão todas raízes da equação proposta.

Contudo, se o número estabelecido [ou designado] dos quadrados for sabido positivo [nota plus], a linha $\mathrm{AB}$ será a parte média do agregado [ou soma] da unidade e do número dos quadrados, e será assumido dentro da parábola. Mas se (o número) estabelecido for sabido negativo [nota minus], a linha $\mathrm{AB}$ será parte média [ou metade] da diferença entre a unidade e o número dos quadrados ${ }^{154}$; e dentro da parábola, se aquela diferença for menor que a unidade; contudo, se for maior, será fora (da parábola); se igual, no vértice.

Além disso, a linha $\mathrm{BC}$ será parte média [ou metade] do número das raízes. E consequentemente o semidiâmetro do círculo CD será raíz quadrada do agregado dos quadrados feitos sobre [supra] a linha CA e dos números absolutos, se de fato for sabido positivo [nota plus]; contudo, se for sabido negativo [nota minus], o semidiâmetro CD será raiz da diferença, da qual o quadrado da linha CA excedeu o número absoluto. (Com efeito, deve exceder: doutra maneira a raiz é nula em toda a equação, mas [ou] todas imaginárias), \& em geral tantas são raízes verdadeiras na equação, quantos são os pontos nos quais o círculo mencionado corta a parábola além do vértice. E se o número das raízes é sabido negativo [nota minus], elas tanto das verdadeiras raízes serão explícitas [explicitae], das quais as linhas prolongadas da extremidade do centro do círculo cortarão o diâmetro da parábola; as outras, contudo, serão implícitas [implicitae]. E, em oposição, se o número das raízes é sabido positivo [nota plus], elas serão raízes explícitas, que se fixam [se tenent] na parte da parábola que é centro do círculo, \& implícitas, que são encontradas noutra parte seja ela qual for. E nada nessa regra é passiva de exceção ou defeito.

D. des Chartes tanto fez essa descoberta que ele confessou nunca ter descoberto algo tão excepcional, e que ninguém descobrira algo mais excepcional.

\footnotetext{
${ }^{154}$ Bos encontrou um erro nessa passagem. Deve-se ler p ao invés de $|1-p|$. Cf. BOS, 2001, 257,
} nota 8 . 


\title{
7.3
}

\section{Construção de Roberval para duas médias proporcionais (Harmonie universelle contenant la théorie et la pratique de la musique) ${ }^{155}$}

\author{
PROPOSIÇÃO XLV
}

Entre duas linhas retas desiguais dadas, encontrar duas médias continuamente proporcionais, para dividir o Diapasão dos Órgãos em doze semitons iguais.

Essa construção é, a meu ver, a mais simples de todas aquelas que foram descobertas até agora para a solução desse Problema, do qual depende a tão célebre duplicação do Cubo, \& que tanto foi buscada pelos Geômetras Antigos \& Modernos: de modo que, nos Comentários de Eutócio a Arquimedes, encontra-se onze Autores dos mais renomados entres os Antigos, sem aqueles de nosso tempo, que apresentaram a demonstração ora por lugares sólidos, como Menêcmo; outros por lugares lineares , como Nicomedes, Diocles, \& nosso Viète; \& e outros envolvendo movimentos, como Platão, Arquitas, Fílon de Bizâncio, Pappus, \& Sporus; ou por descrições de círculos à sorte, como Heron, \& Apolônio: deixando a parte um grande número de outros, o quais, ao invés de demonstrações, não nos deram senão Paralogismos. Ora como os Antigos, segundo o relato de Pappus, estimaram que era um grande erro resolver por lugares sólidos ou lineares, um Problema, que de sua natureza poderia ser resolvido por apenas lugares planos: eu estimo da mesma maneira que o erro não é menor se se resolve por lugares lineares, ou envolvendo movimentos, ou por descrições à sorte, um Problema, que por sua natureza pode ser resolvido por lugares sólidos. Pois, uma vez que entre os lugares a ordem é tal, aqueles que chamamos planos são os mais simples, a saber: linha reta, \& a circunferência do círculo, a descrição dos quais Euclides estabelece no início de seus Elementos: em seguida estão os lugares sólidos, que têm sua origem na secção de uma superfície Cônica, construída por uma linha reta e pela circunferência de um círculo, e podem ser: Parábola, Elipse, \& Hipérbole: que são seguidas pelos lugares que denominados lineares, construídos o mais das vezes por dois movimentos envolvidos, como as Concóides, as Espirais, Quadratrizes, e uma infinidade de outras, cuja descrição é de costume quase

${ }^{155}$ Cf. (AT, X, 653-658). 
impossível: parece razoável que todo Problema que pode ser resolvido por lugares planos, seja resolvido por lugares planos: \& que aquele que, não podendo ser resolvido apenas por lugares sólidos, possa sê-lo por lugares sólidos, ou misturados com lugares planos, deve ser resolvido por lugares sólidos apenas, ou misturados com lugares planos: enfim quando um problema é de tal natureza que não pode ser resolvido por lugares planos ou sólidos, então é permitido de resolvê-lo por lugares lineares apenas, ou misturados com lugares planos, \& sólidos: de modo que se sirva dos lugares planos sempre que possível, \& o menos que se possa dos outros; \& que uma construção na qual entrará somente um lugar sólido, sendo o resto plano, seja mais estimada que aquela na qual entrarão dois lugares sólidos, uma vez que, à imitação da natureza, nós devemos fazer tudo pelos meios mais simples.

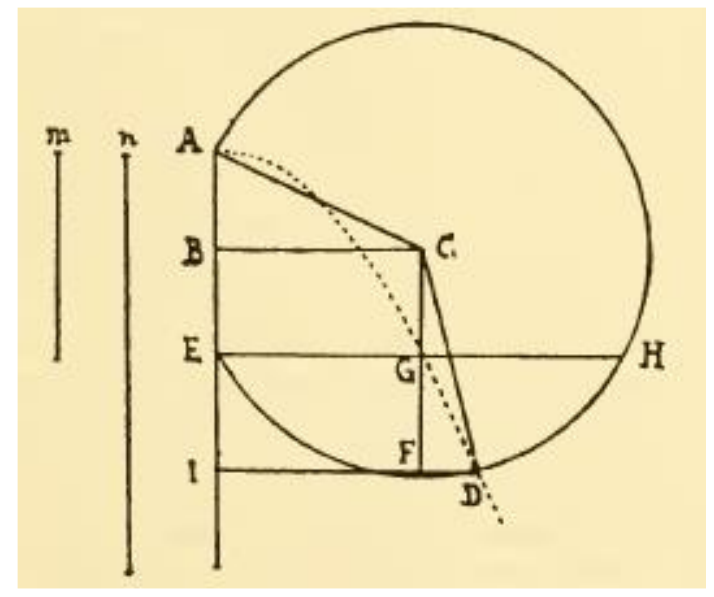

Figure 9 (AT, X, 655)

Sejam duas linhas retas desiguais dadas, $m, n$, das quais $m$ seja a menor: e que entre as duas se deva encontrar duas médias continuamente proporcionais. Sejam AE, EH, duas linhas retas perpendiculares uma a outra, das quais AE seja igual a $m$, e EH igual a $n$ : e seja $\mathrm{AE}$ seccionada igualmente em duas no ponto $\mathrm{B}$, do qual sobre $\mathrm{AE}$ seja traçada a perpendicular $\mathrm{BC}$, bem como $\mathrm{EH}$, e igual à metade da mesma EH: seja assim prolongada a linha CA: e do centro $\mathrm{C}$ e do intervalo CA seja descrito um círculo, do qual a circunferência passará pelos pontos A, H, E: o que é fácil de demonstrar. Em seguida, assumindo a linha dada AE por posição do eixo de uma parábola, e o comprimento da mesma AE como latus rectum: seja descrita a parábola $\mathrm{AGD}$, contanto a linha $\mathrm{EH}$ no ponto $\mathrm{G}$, e a circunferência do círculo no ponto D. No entanto, é claro que a parábola corta a 
linha EH, perpendicular ao eixo AE; que ela corta, prova-se assim: ${ }^{156}$ a circunferência do círculo entre os pontos E, H, na medida em que a linha EG, conforme a natureza da parábola, ${ }^{157}$ é igual ao latus rectum $\mathrm{AE}$, que é menor, por suposição, que EH; e o ponto G que está na parábola, e está no círculo; assim, a parábola passa no círculo entre os pontos E, H: e depois ela se estende infinitamente, sendo o círculo finito, ela sairá, e cortará a circunferência no ponto $D$ entre $E$ e $H$. Seja então, do ponto D sobre o eixo prolongado AE, prolongada a perpendicular DI. Eu digo que DI e AI são as duas médias proporcionais que se pede.

Uma vez que seja prolongada a linha CD, e CF perpendicular a ID, a qual CF cairá ou entre I, D, ou no ponto D, ou sobre ID prolongada além do ponto D. Que ela caia, então, entre I, D; visto que esse caso sendo demonstrado, os dois outros não terão nenhuma dificuldade. Depois, então, que DI é cortada em F, segue-se, pela sétima Proposição do segundo livro de Euclides, que os dois quadrados DI, IF, ou DI, BC, são iguais ao quadrado DF e a duas vezes o retângulo DIF: mas duas vezes o retângulo DIF é igual ao retângulo contido por DI e $n$, porque $n$ é o dobro de BC [, que é igual, por sua vez, é] igual a IF; então os dois quadrados DI, BC são iguais ao quadrado DF e ao retângulo contido por DI e $n .{ }^{158}$ Similarmente, pela mesma sétima Proposição do segundo livro de Euclides, os quadrados $\mathrm{AI}, \mathrm{AB}$ são iguais ao quadrado $\mathrm{BI}$ ou $\mathrm{CF}$, e a duas vezes o retângulo $\mathrm{IAB}$, ou somente ao retângulo IAE; isto é, que os quadrados $\mathrm{AI}, \mathrm{AB}$, são iguais ao quadrado CF e ao retângulo IAE. ${ }^{159}$ Sejam então adicionadas coisas iguais a coisas iguais, a saber: dois quadrados DI, BC, aos dois quadrados AI, AB; e o quadrado DF com seu retângulo contido por DI e $n$, ao quadrado CF e a seu retângulo IAE: desse modo, os quatro quadrados DI, BC, AI, e AB, serão iguais aos dois quadrados DF, CF, e aos dois retângulos, um dos quais é contido por DI e

\footnotetext{
${ }^{156} \mathrm{~A}$ parábola corta a circunferência num determinado ponto $\mathrm{D}$, que não pode fugir à distância que fica entre o ponto E e o ponto $\mathrm{H}$. Dessa maneira, a configuração do diagrama apresentado por Roberval parece obedecer a certos critérios de invariabilidade.

157 Roberval evoca a propriedade (symptoma) da parábola utilizada pelos antigos - que, algebricamente, pode ser formulada da seguinte maneira: $y^{2}=a x$, sendo $a$ o latus rectum.

${ }^{158} \mathrm{~A}$ partir da proposição euclidiana II.7, obtém-se: $\mathrm{DI}^{2}+\mathrm{IF}^{2}=\mathrm{DF}^{2}+2(\mathrm{DI} \times \mathrm{IF})$. E uma vez que $n=2 \times \mathrm{BC}$ e IF $=\mathrm{BC}$, consequentemente: $2(\mathrm{DI} \times \mathrm{IF})=\mathrm{DI} \times n$.

${ }^{159} \mathrm{~A}$ partir da proposição euclidiana II.7, obtém-se: $\mathrm{AI}^{2}+\mathrm{AB}^{2}=\mathrm{BI}^{2}+2(\mathrm{IA} \times \mathrm{AB})$. E uma vez que $\mathrm{BI}=\mathrm{CF}$, consequentemente: $\mathrm{AI}^{2}+\mathrm{AB}^{2}=\mathrm{CF}^{2}+2(\mathrm{IA} \times \mathrm{AB})$. Mas, dado que $2 \mathrm{AB}=\mathrm{AE}$, se pode ter a equação: $\mathrm{AI}^{2}+\mathrm{AB}^{2}=\mathrm{CF}^{2}+\mathrm{IA} \times \mathrm{AB}$.
} 
$n$, e o outro é IAE. ${ }^{160}$ Mas dos quatro quadrados os dois $\mathrm{CB}, \mathrm{AB}$, são iguais ao $\mathrm{CD}$ somente; e $\mathrm{AC}$ é igual a $\mathrm{CD}$, por causa do círculo: ${ }^{161}$ sejam então eliminados esses quadrados iguais, $\mathrm{AC}, \mathrm{CD}$, e permanecerão os dois quadrados $\mathrm{DI}$ e $\mathrm{AI}$, de um lado, iguais aos dois retângulos contidor por DI e n, e por IAC, de outro lado. ${ }^{162}$ Mas o quadrado DI é igual ao retângulo IAE, por causa da parábola, da qual $\mathrm{AE}$ é latus rectum; sejam então eliminadas essas partes iguais, e permanecerá o único quadrado $\mathrm{AI}$, igual ao único retângulo contido por DI e $n$. Portanto, a linha $n$ está para AI, como AI está para ID; mas AI está para ID, como ID está para o latus rectum $\mathrm{AE}$ ou $m$, por causa da parábola: assim as linhas $n, \mathrm{AI}$, ID, e $m$ são continuamente proporcionais: e os extremos $n, m$ estão dadas; e nós achamos as médias AI, e ID, que é o que se pede. ${ }^{163}$

No segundo caso, quando a perpendicular $\mathrm{CF}$ cai sobre o ponto $\mathrm{D}$, as linhas CF e CD coincidem, e a linha ID corta o círculo, e igual a BC: isso ocorre quando $n$, a maior das extremidades dadas, é o óctuplo em potência da menor extremidade $m$ : portanto, o Problema no mesmo caso é plano e as linhas são continuamente o dobro em potência uma da outra, isto é: como o diâmetro de um quadrado a seu lado; como aparece na demonstração seguinte, que é fácil. Pois, pela sétima proposição do segundo livro de Euclides, os quadrados AI, AB, são iguais ao quadrado $\mathrm{BI}$, ou $\mathrm{CF}$, ou $\mathrm{CD}$, e a duas vezes o retângulo IAB, ou apenas ao retângulo IAE, ou ao quadrado ID, ou $\mathrm{BC}$ : e adicionando em uma parte e na outra o quadrado $\mathrm{BC}$, nós teremos os três quadrados $\mathrm{AI}, \mathrm{AB}$, e $\mathrm{BC}$, iguais aos três $\mathrm{CD}$, ID, e BC. Mas, dos três primeiros, os dois AB, BC, são iguais a apenas $\mathrm{AC}$, igual a CD. Sejam então cortadas de uma parte e de outra os quadrados AC, CD, e restará apenas o quadrado AI, igual aos dois ID, BC, os quais, sendo iguais nesse caso, o quadrado AI fará o dobro do quadrado ID, ou do quadrado de BC: mas o

\footnotetext{
${ }^{160}$ Algebricamente, isso pode ser lido da seguinte maneira: $\mathrm{DI}^{2}+\mathrm{BC}^{2}+\mathrm{AI}^{2}+\mathrm{AB}^{2}=\mathrm{DF}^{2}+$ $\mathrm{DI} \times n+\mathrm{CF}^{2}+2(\mathrm{IA} \times \mathrm{AB})$.

${ }^{161}$ Sabe-se, por Pitágoras: $\mathrm{AC}^{2}=\mathrm{AB}^{2}+\mathrm{BC}^{2}$ e que $\mathrm{CD}^{2}=\mathrm{DF}^{2}+\mathrm{CF}^{2}$. E, dado que $\mathrm{AC}$ e $\mathrm{CD}$ são iguais porque equivalem ao raio de um mesmo círculo, logo é sabido que $\mathrm{AB}^{2}+\mathrm{BC}^{2}=\mathrm{DF}^{2}+$ $\mathrm{CF}^{2}$.

${ }^{162}$ Simplifica-se a equação a partir da observação feita na nota 7 e da aplicação do axioma I.3 de Euclides: $\mathrm{DI}^{2}+\mathrm{AI}^{2}=\mathrm{DF}^{2}+\mathrm{DI} \times n+2(\mathrm{IA} \times \mathrm{AB})$, ou $\mathrm{DI}^{2}+\mathrm{AI}^{2}=\mathrm{DF}^{2}+\mathrm{DI} \times n+\mathrm{IA} \times \mathrm{AE}$ simplesmente.

${ }^{163}$ Aplica-se a propriedade da parábola envolvendo o latus rectum (AE), e aplica-se o axioma I.3 de Euclides: $\mathrm{DI}^{2}=\mathrm{IA} \times \mathrm{AE}$. E, consequentemente, obtém-se a equação $\mathrm{AI}^{2}=\mathrm{DI} \times n$. As duas equações podem ser escritas numa relação de duas médias proporcionais da seguinte maneira: $\frac{m}{\mathrm{DI}}=$ $\frac{\mathrm{DI}}{\mathrm{AI}}=\frac{\mathrm{AI}}{n}$.
} 
dobro do quadrado de $\mathrm{BC}$, ou ID, é igual ao retângulo contudo por ID e $n$, para o qual $n$ é o dobro de BC, ou ID: então o quadrado de AI é igual ao retângulo sob ID e $n$, de onde se segue que as três linhas $n$, AI, e ID, são proporcionais: e os três AI, ID e AE, ou $m$, sendo também proporcionais, por causa da parábola, os quatro $n$, AI, ID e $m$ serão continuamente proporcionais: o que se pede. E depois que se provou que o quadrado de AI é o dobro do quadrado de ID, parece que as quatro linhas são continuamente o dobro uma da outra; e que $n$ fará óctuplo em potência de $m$.

No terceiro caso, quando a perpendicular CF cai sobre ID prolongada além de D: é o que acontece quando a extremidade dada é menor que o óctuplo em potência da menor: a demonstração é inteiramente como no primeiro caso, sem mudar uma única letra nem uma só palavra: exceto que os dois pontos, onde a linha ID corta a circunferência do círculo, o ponto D é o mais próximo do ponto I, visto que no primeiro caso ele é o mais longo do mesmo ponto I. 